UNIVERSIDADE DE SÃO PAULO

FACULDADE DE ECONOMIA, ADMINISTRAÇÃO E CONTABILIDADE DEPARTAMENTO DE ADMINISTRAÇÃO PROGRAMA DE PÓS-GRADUAÇÃO EM ADMINISTRAÇÃO

ELEMENTOS MOTIVADORES E INIBIDORES NO COMPORTAMENTO DE COMPRA NO VAREJO ONLINE

Renato Cortopassi Pelissaro

Orientador: Prof. Dr. Celso Cláudio de Hildebrand e Grisi

SÃO PAULO 
Profa. Dra. Suely Vilela

Reitora da Universidade de São Paulo

Prof. Dr. Carlos Roberto Azzoni

Diretor da Faculdade de Economia, Administração e Contabilidade

Prof. Dr. Isak Kruglianskas

Chefe do Departamento de Administração

Prof. Dr. Lindolfo Galvão de Albuquerque

Coordenador do Programa de Pós-Graduação em Administração 


\title{
ELEMENTOS MOTIVADORES E INIBIDORES NO COMPORTAMENTO DE COMPRA NO VAREJO ONLINE
}

\author{
Dissertação apresentada ao Departamento de \\ Administração da Faculdade de Economia, \\ Administração e Contabilidade da \\ Universidade de São Paulo como requisito \\ para a obtenção do título de Mestre em \\ Administração de Empresas.
}

Orientador: Prof. Dr. Celso Cláudio de Hildebrand e Grisi

SÃO PAULO 


\section{FICHA CATALOGRÁFICA}

Elaborada pela Seção de Processamento Técnico do SBD/FEA/USP

\section{Pelissaro, Renato Cortopassi}

Elementos motivadores e inibidores no comportamento de compra no varejo online / Renato Cortopassi Pelissaro. -- São Paulo, 2009.

$133 \mathrm{p}$

Dissertação (Mestrado) - Universidade de São Paulo, 2009 Bibliografia.

1. Marketing on-line 2. Comércio eletrônico 3. Comportamento 4. Varejo I. Universidade de São Paulo. Faculdade de Economia, Administração e Contabilidade. II. Título.

$$
\text { CDD - } 658.84
$$


Aos meus pais e minha esposa, por todo apoio e dedicação. 


\section{AGRADECIMENTOS}

Agradeço aos meus pais, Adimicio e Regina, por estarem sempre ao meu lado, me apoiando e incentivando em todas as etapas e conquistas da minha vida.

Agradeço ao professor Celso Grisi por todo o apoio, amizade, conselhos, orientações e sabedoria, sem os quais seria absolutamente impossível ter levado a frente este mestrado.

Aos professores Lino Nogueira Filho e Francisco Serralvo pelas valiosas contribuições e recomendações dadas durante a fase de qualificação deste projeto de pesquisa, que certamente ajudaram a torná-lo melhor e mais coeso.

A todos os colegas e professores da FEA/USP com quem tive o prazer de conviver ao longo destes dois anos, e que me proporcionaram a bagagem e o enriquecimento cultural necessários para me tornar melhor pessoalmente e profissionalmente.

Igualmente não poderia deixar de agradecer aos meus empregadores, Microsoft e Yahoo, que não somente souberam entender e reconhecer o valor do conhecimento na vida de uma pessoa, como me apoiaram e deram todo o suporte para que eu seguisse em frente nesta jornada.

E finalmente, agradeço muito à minha esposa, Fernanda, pela compreensão, pelo incentivo, pelo amor e pela parceria, tanto nos bons momentos quanto nos momentos difíceis deste mestrado. Seu apoio e sua presença ao meu lado foram o lastro forte que sempre me fizeram seguir adiante e tornar meus sonhos em realidade. 


\section{RESUMO}

O crescimento da Internet ao longo dos últimos anos como canal de vendas e canal de relacionamento entre as empresas e seus consumidores acabou por torná-la uma das principais apostas das grandes redes de varejo para a expansão dos negócios e aumento de sua performance operacional. Dentro deste contexto, o objetivo desta dissertação é contribuir à formação do conhecimento na área pesquisando o comportamento do comprador online brasileiro, especificamente alguns dos elementos motivadores e inibidores de compra, além de outros aspectos relacionados à frequência de compra, satisfação com o meio e indicadores demográficos. Para cumprir tais objetivos, foi realizada uma revisão bibliográfica passando pela literatura acerca de comportamento do consumidor e de estudos empíricos voltados especificamente à área de Internet. Complementarmente, foi conduzida uma pesquisa de campo quantitativa com 238 usuários de Internet brasileiros, visando contrapor os resultados às referências teóricas pesquisadas. Os resultados do estudo apontam a existência de diferentes níveis de importância entre os elementos determinantes do meio de compra (a destacar os fatores de preço e facilidade de acesso), além de identificar relações significativas positivas entre a intensidade de uso da Internet e a quantidade de compras realizadas online; e também entre a satisfação com as compras online e a intenção de realização de compras futuras pelo meio.

Palavras-chave: Marketing online. Comércio eletrônico. Comportamento. Varejo. 


\begin{abstract}
The growth of the Internet over the last years as a sales channel and as a relationship channel between companies and its costumers has ultimately made it one of the main bets of the largest retail chains for achieving business growth and for increasing their operating performance. In this context, the objective of this dissertation is to provide a contribution to the knowledge development in the area by researching the buyers' behavior in Brasil, specifically some of the motivators and inhibitors elements of the online purchase, along with its correlation to other related aspects, such as purchase frequency, medium satisfaction on purchase, and key demographics of the online buyer. In order to reach these goals, a literature review has been conducted over consumer behavior references as well as empiric studies more specifically oriented to the dissertation discussion area. A quantitative field research has also been conducted with 238 Brazilian Internet users, with the main purpose of comparing the survey results to the literature review findings. The study results indicate the existence of different importance levels among the determing elements of the purchase mean (to be highlighted the importance of the price and easy access factors), besides pointing out positive and significative correlations between the intensity of Internet usage and purchase behavior; and between online purchases satisfaction and future purchase intention.
\end{abstract}

Keywords: Online marketing. E-commerce. Customer Behavior. Retail. 


\section{SUMÁRIO}

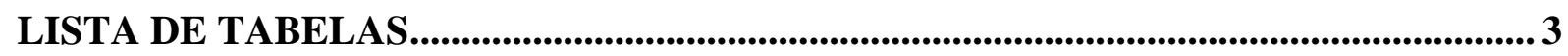

LISTA DE GRÁFICOS ................................................................................................. 4

1 INTRODUÇÃ

1.1 O mercado de Internet no Brasil.................................................................................. 8

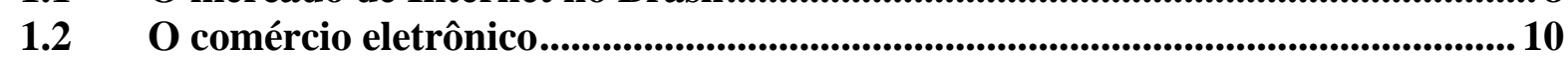

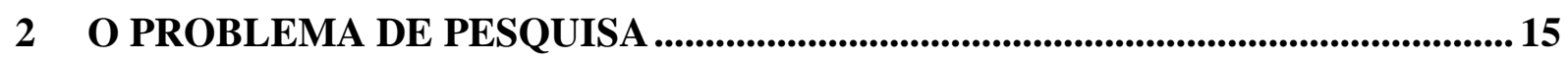

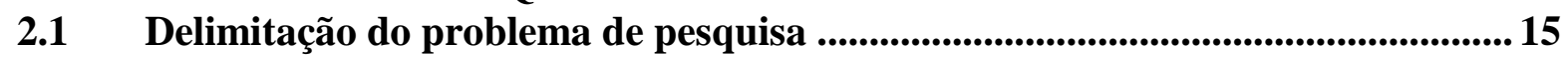

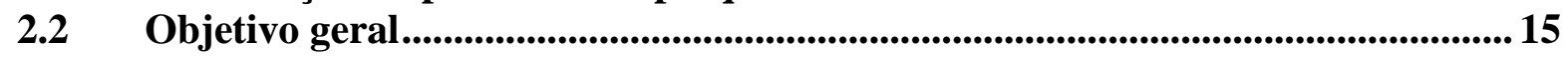

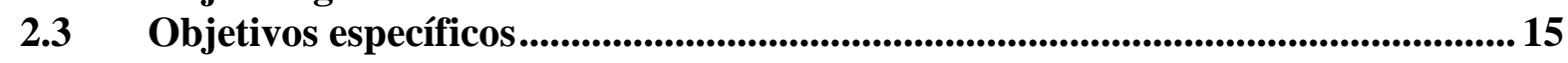

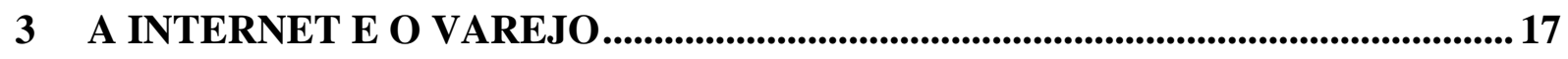

3.1 A importância da Internet no contexto do varejo brasileiro ................................ 17

3.1.1 Aumento da receita total e do gasto médio dos clientes ........................................ 19

3.1.2 Expansão da cobertura geográfica ....................................................................... 21

3.1.3 Maior sortimento de produtos e diminuição dos custos de geração de vendas ..... 22

3.2 Razões para opção por não desenvolver uma estratégia online .......................... 24

4 COMPORTAMENTO DO CONSUMIDOR............................................................ 31

4.1 Processo de decisão do consumidor ......................................................................... 33

4.1.1 Busca de informações .................................................................................. 34

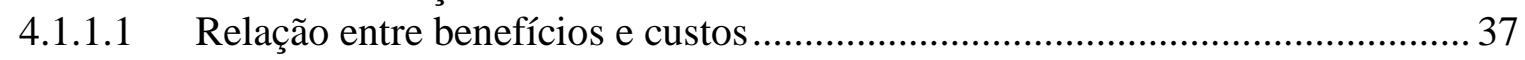

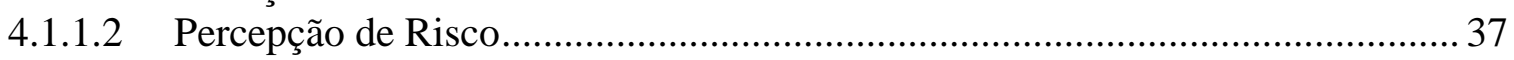

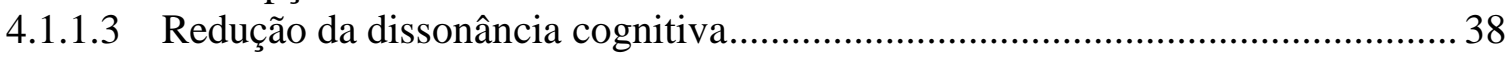

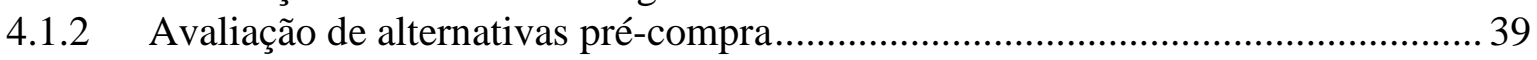

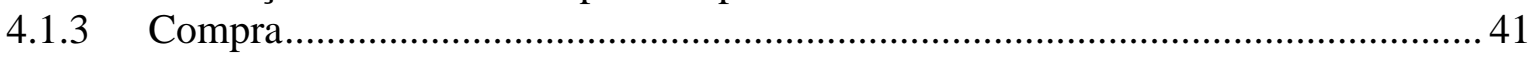

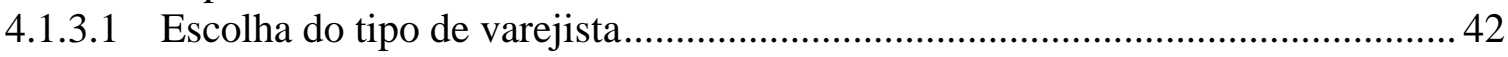

4.2 Motivadores e inibidores de compra online ................................................................... 44

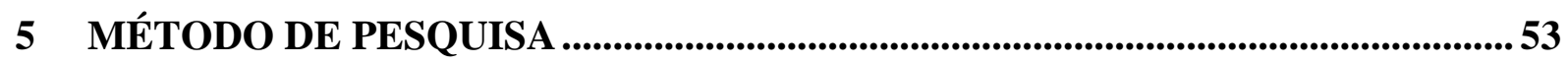

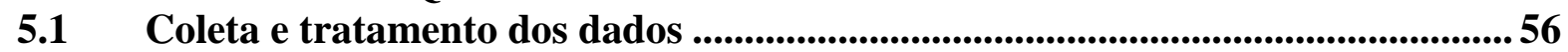

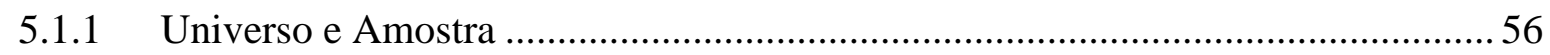

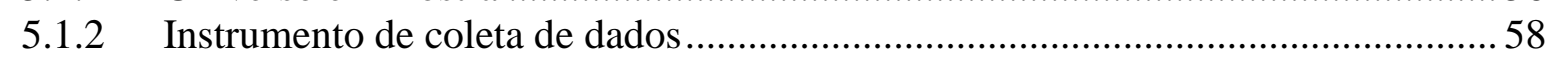

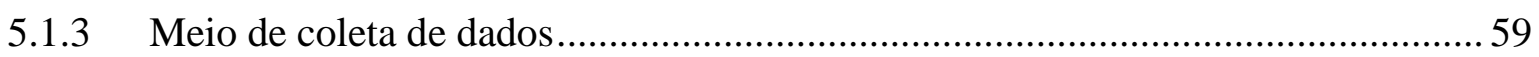

5.2 Testes e procedimentos para análise dos dados ....................................................60

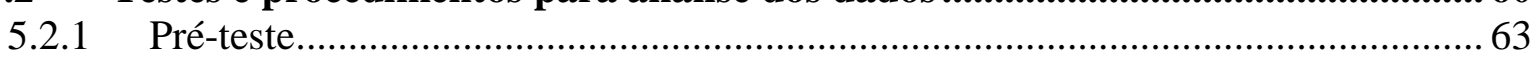

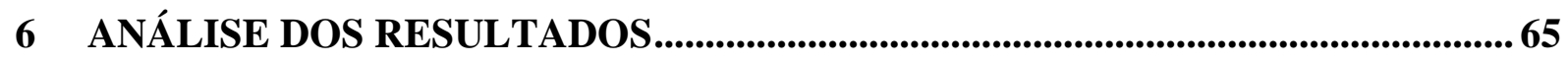

6.1 Características demográficas da amostra ................................................................6 65

6.2 Preparação dos dados.......................................................................................................... 72

6.3 Análise dos resultados - Objetivo específico 1 1............................................................. 73

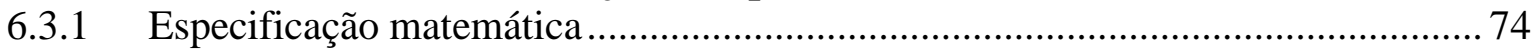

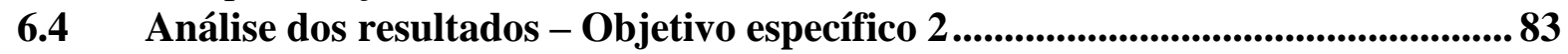

6.5 Análise dos resultados - Objetivo específico 3............................................................. 89

6.6 Análise dos resultados - Objetivo específico 4 ........................................................... 91

7 CONCLUSÕES, LIMITAÇÕES E RECOMENDAÇÕES .....................................97

7.1 Limitações e recomendações..................................................................................... 103

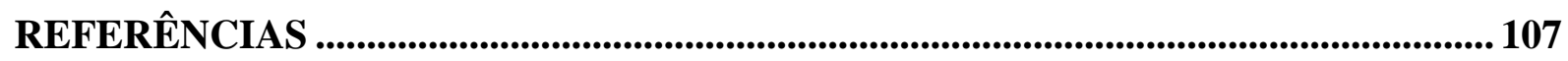




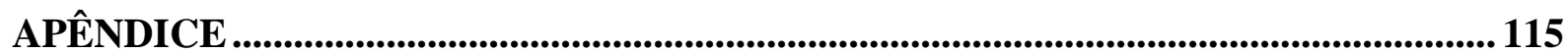

- Questionário - Pesquisa de campo ............................................................................................. 115

- Processamento completo - Regressão logística dos dados ............................................. 120

- Resultados da Pesquisa - Não ponderados............................................................................. 121 


\section{LISTA DE TABELAS}

Tabela 1 - Faturamento anual do varejo online no Brasil (em R\$) 9

Tabela 2 - Tipos de processo de decisão de compra, quanto ao planejamento

Tabela 3 - Participação nas vendas das principais categorias de produtos vendidos na Internet no Brasil 60

Tabela 4 - Detalhamento dos objetivos específicos. 62

Tabela 5 - Distribuição demográfica usada para ponderação dos dados da amostra .72

Tabela 6 - Resumo da avaliação dos elementos motivadores e inibidores de compra online 76

Tabela 7 - Importância dos fatores na decisão do meio de compra......................................... 80

Tabela 8 - Kendall's tau_b - Correlation Coefficient - OE 2 …......................................... 85

Tabela 9 - Cruzamento de informações entre experiência de uso da Internet, comportamento de compra e intenção de compra (\% dos respondentes).

Tabela 10 - Cruzamento de informações entre a intensidade de uso da Internet, comportamento de compra e intenção de compra (\% dos respondentes).............. 87

Tabela 11 - Kendall's tau_b - Correlation Coefficient - OE 3 ................................................ 89

Tabela 12 - Relação entre satisfação pós-compra pela Internet e intenção de compra (\% dos respondentes).

Tabela 13 - Principais dados demográficos entre compradores e não-compradores online .... 93

Tabela 14 - Importância dos elementos para a decisão do meio de compra e diferença das avaliações entre loja online e loja física ............................................................. 100

Tabela 15 - Relação entre satisfação pós-compra pela Internet e intenção de compra (\% dos

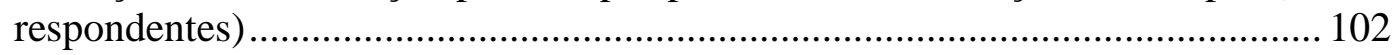




\section{LISTA DE GRÁFICOS}

Gráfico 1 - Evolução da população total e internautas no Brasil (em milhões) ........................ 8

Gráfico 2 - Usuários de Internet que realizaram compras online em relação ao total da base de

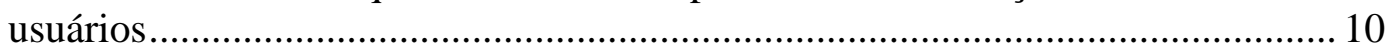

Gráfico 3 - Compradores online* no Brasil - 2001 a 2007 (em milhões)................................ 31

Gráfico 4 - Evolução do gasto médio em compras realizadas na Internet no Brasil - 2001 a

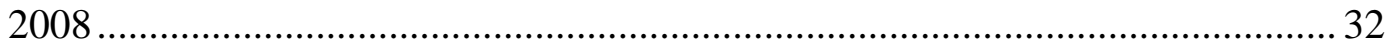

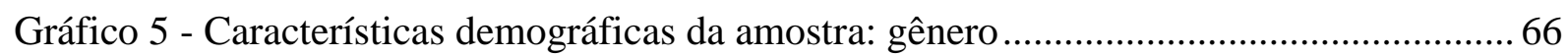

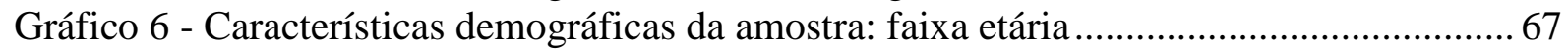

Gráfico 7 - Características demográficas da amostra: faixa etária - por gênero....................... 68

Gráfico 8 - Características demográficas da amostra: grau de instrução .................................69

Gráfico 9 - Características demográficas da amostra: ocupação........................................... 70

Gráfico 10 - Características demográficas da amostra: renda pessoal ..................................... 71

Gráfico 11 - Matriz de importância e avaliação do meio ........................................................ 82 


\section{INTRODUÇÃO}

Rupturas tecnológicas frequentemente representam momentos-chave de quebra de paradigmas no ambiente de negócios; sejam elas relacionadas às técnicas de produção, comercialização, relacionamento com os clientes ou surgimento de novas forças propulsoras (FREEMAN, 1991).

Em alguns casos, estas mudanças criam pressões competitivas que afetam de tal modo o ambiente de negócios em que a companhia atua, que reagir rápida e habilmente aos novos desafios que são colocados parece ser o ponto crítico da sobrevivência de determinadas empresas.

O surgimento da Internet - sob diversas perspectivas diferentes - pode ser visto como um destes marcos de ruptura tecnológica dos paradigmas tradicionais (SHARMA, 2002). E como tal, tanto pode alavancar as oportunidades de geração de negócios de uma empresa quanto levar à bancarrota aquelas menos preparadas para o novo ambiente de competição.

Evidentemente, nem todos os autores têm uma visão tão radical do papel da rede na realidade do mercado. Porter (2001), por exemplo, argumenta que embora a Internet seja uma tecnologia extremamente importante, ela não muda a essência e a importância do papel da estratégia dos negócios, e deve ser entendida simplesmente como uma tecnologia que potencializa a captura de benefício econômico do mercado.

No entanto, o fato é que o impacto que o advento da Internet representou nos negócios expandiu amplamente seus propósitos originais, circunscritos aos meios acadêmicos e militares. Originalmente concebida como uma forma de facilitar o acesso de órgãos de defesa do governo dos Estados Unidos às informações surgidas em locais remotos com maior rapidez, foi particularmente na esfera civil - especialmente por seu impacto econômico - na qual a rede modificou a forma como as pessoas se relacionam, trocam informações e consomem produtos e serviços. 
Com a possibilidade de enviar e receber informações em tempo real em praticamente qualquer ponto do planeta, a comunicação interpessoal passou por um intenso processo de catalisação, que, por sua vez, acarretarou enormes mudanças na forma como as pessoas encontram novos fornecedores, buscam informações sobre produtos e serviços, tomam decisões de compra e investimentos, controlam tempos e etapas de entrega e avaliam níveis de serviço (BAKOS, 1997).

A dificuldade e o custo do acesso às informações para a tomada de decisão por empresas e indivíduos reduziu-se drasticamente; a integração de mercados e a circulação de ideias, produtos e serviços foi intensificada sem paralelos na história moderna (BAKOS, 1997).

Mesmo no consumo pessoal, a facilidade de acesso à informação transformou intensamente a forma como as pessoas realizam as diferentes etapas do processo de compra: reconhecimento da necessidade, busca de informações, avaliação das alternativas pré-compra, compra, consumo, avaliação pós-consumo e descarte (BLACKWELL et al, 2005).

Ao longo dos últimos anos, a etapa da compra realizada online tem recebido particular atenção da academia e do meio empresarial, não apenas pelo impacto direto que tem nos resultados e operações das empresas, mas por ser um estágio em que há a canalização de diversos fatores e vetores materiais e emocionais que interferem - positiva ou negativamente - neste processo (CONSTANTINIDES, 2004).

Entender o peso de cada um destes elementos (conveniência, facilidade de comparação, medo de realizar uma transação pela Internet, impossibilidade de trocar o produto, etc.) e como estes elementos atuam conjuntamente na efetivação da compra online, é elemento preponderante para aumentar o desempenho das organizações envolvidas (McKENNA, 2000).

Outro aspecto resultante deste cenário de grande efervescência econômica, social e cultural proporcionado pelo meio é que a competição entre empresas acabou tendo um substancial incremento (ALBERTIN, 2002; McKENNA, 2000).

Para as empresas varejistas, as oportunidades e ameaças são as mais diversas. Se, por um lado, atuar fora dos limites geográficos cobertos pelas lojas físicas das empresas representa uma interessante possibilidade de atingir novos mercados consumidores, por outro, a disputa 
pelo fornecimento de produtos e serviços para empresas e consumidores finais tornou-se muito mais acirrada.

A forma como as empresas estabelecem suas operações para vendas na Internet também apresenta significativas diferenças, podendo adquirir diversas configurações. Segundo Churchill e Peter (2000), uma primeira distinção pode ser convencionada entre varejistas com loja e varejistas sem loja; ou seja, os primeiros realizam suas transações comerciais em ambientes físicos definidos e o segundo grupo realiza suas transações sem a necessidade de um ambiente físico de interação entre consumidor e o agente vendedor.

Outras denominações usadas para classificar os negócios de redes varejistas realizados online tomam por base o modelo principal de negócios: as empresas start-ups, que realizam seus negócios originalmente e unicamente pela rede; e as empresas tradicionais que passaram a desenvolver uma estratégia específica de exploração das potencialidades da rede, particularmente a partir do boom de adoção da Internet ocorrido no país na década de 2000 (CHURCHILL, PETER, 2000).

Fleury (2001) aponta que, não raramente, as empresa optam pelo estabelecimento de uma divisão "ponto com" separada, como condição para conseguir a agilidade necessária para competir com as start-ups. Já Turban (2000) classifica os negócios desenvolvidos na Internet em 4 diferentes tipos baseados nos indivíduos envolvidos no processo transacional: o business to business (B2B), que engloba transações interorganizacionais e transações no mercado eletrônico entre organizações, o business to consumer (B2C), que inclui transações entre varejistas e compradores individuais, o consumer to consumer $(\mathrm{C} 2 \mathrm{C})$, que acontece quando consumidores vendem diretamente a outros consumidores, e por fim, o consumer to business (C2B), nos quais consumidores vendem diretamente seus produtos a organizações.

No presente trabalho, serão analisadas especificamente as transações efetuadas entre empresas varejistas e compradores individuais (B2C). Particularmente, o foco da análise são os elementos motivadores e inibidores do comportamento de compra realizada pela rede, avaliados à luz das teorias de comportamento do consumidor.

Para tanto, será realizada uma revisão da literatura acerca do tema, e uma pesquisa de campo que será levada a cabo com usuários de Internet como forma de identificar informações e aspectos que representem um avanço no estado da arte do conhecimento na área. 


\subsection{O mercado de Internet no Brasil}

Ao longo dos últimos anos, o mercado de Internet no Brasil vem crescendo a taxas extremamente elevadas, como resultado da queda dos custos de aquisição de computadores e do acesso à rede por provedores especializados.

Negroponte (1995) revela que não apenas o Brasil, mas a América Latina como um todo, apresenta traços específicos que a tornam interessante para o desenvolvimento da economia digital, particularmente desde o processo de desregulamentação das telecomunicações ocorrido no final da década de 1990.

O gráfico 1 apresenta a evolução do número de usuários ativos de Internet no Brasil em relação ao crescimento da população total.

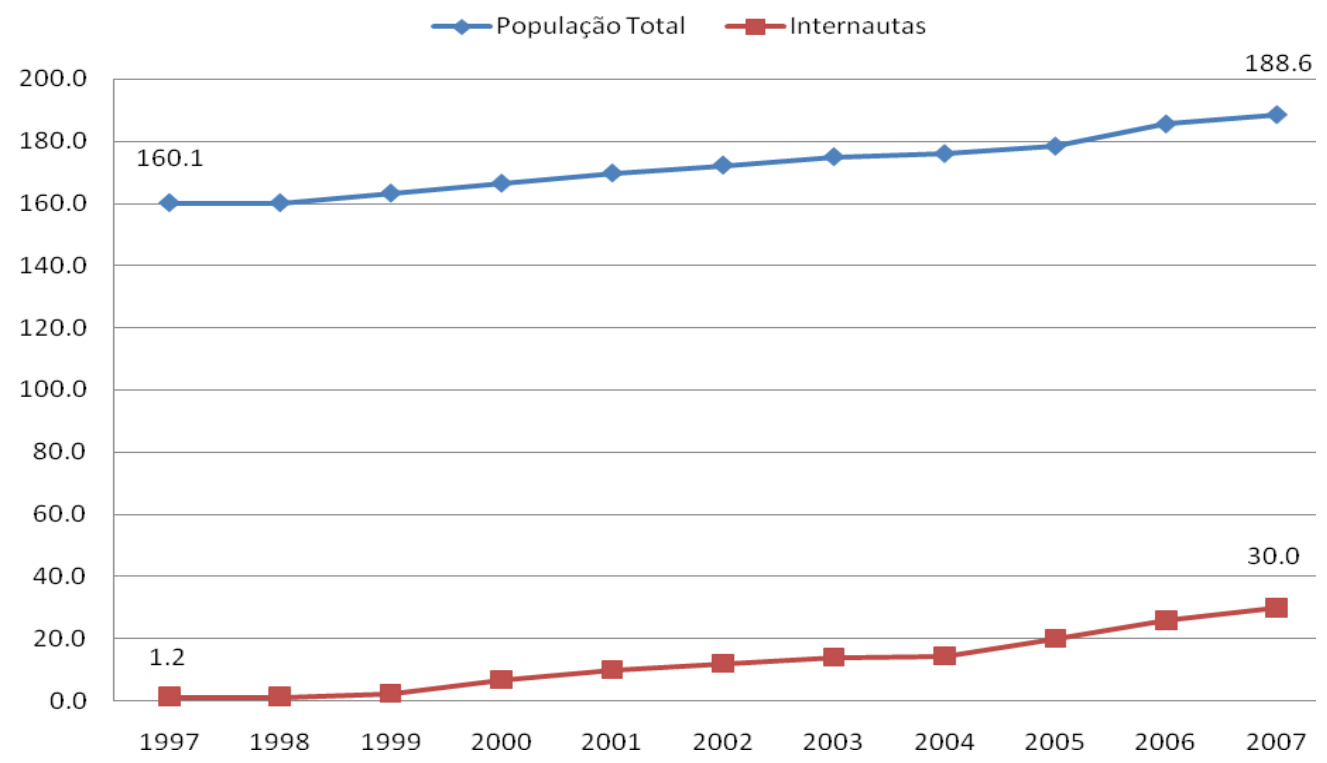

Gráfico 1 - Evolução da população total e internautas no Brasil (em milhões) FONTE: Compilado por www.e-commerce.org.br.

Aproveitando este cenário de oportunidades proporcionado pelo crescimento da base de usuários de Internet, diversas empresas dos mais variados setores de atuação passaram a 
identificar na Web um grande canal para divulgar seus produtos, atrair clientes e gerar novos negócios (FERRELL et al, 2000).

O varejo, em particular, é um dos setores pioneiros na exploração da Web para alavancar seus negócios; em particular, por meio de lojas virtuais para realizar vendas aos seus clientes.

Com o desenvolvimento de novas tecnologias que permitem realizar transações pela Internet com cada vez mais segurança, o crescimento da oferta de produtos e o número de usuários interessados em comprar online, este setor vem experimentando um forte crescimento de vendas nos últimos anos, como pode ser visto como segue.

A tabela 1 apresenta a evolução do faturamento do varejo em vendas online.

Tabela 1 - Faturamento anual do varejo online no Brasil (em R\$)

\begin{tabular}{|c|c|c|}
\hline ANO & FATURAMENTO & VARIAÇÃO \\
\hline 2007 & $\mathrm{R} \$ 6.40$ bilhões & $45 \%$ \\
\hline 2006 & $\mathrm{R} \$ 4.40$ bilhões & $76 \%$ \\
\hline 2005 & $\mathrm{R} \$ 2.50$ bilhões & $43 \%$ \\
\hline 2004 & $\mathrm{R} \$ 1.75$ bilhões & $48 \%$ \\
\hline 2003 & $\mathrm{R} \$ 1.18$ bilhões & $39 \%$ \\
\hline 2002 & $\mathrm{R} \$ 0.85$ bilhões & $55 \%$ \\
\hline 2001 & $\mathrm{R} \$ 0.54$ bilhões & - \\
\hline
\end{tabular}

FONTE: e-bit - Não considera vendas de automóveis, passagens aéreas e leilões online.

Com o crescimento da importância da rede nas vendas do varejo, as empresas do setor passaram a explorar cada vez mais o próprio meio Internet para divulgar seus produtos e serviços e atrair novos clientes às suas lojas virtuais, aproveitando a vantagem de ter o usuário dentro do próprio ambiente onde a venda pode ser efetivada.

Pesquisa desenvolvida pela Double Click (2006) nos EUA, apontou que a Internet - em suas várias formas de websites, sites de buscas, publicidade, e-mail marketing, e avaliações de especialistas e consumidores finais - representa uma enorme influência no processo de compra de bens e serviços, seja ela online ou offline, representando isoladamente o fator de maior impacto dentro do processo de determinados bens. 


\subsection{O comércio eletrônico}

Desde o início da popularização da Internet no Brasil, a partir da segunda metade da década de 1990, o comércio eletrônico entre empresas e consumidores finais (B2C) tem crescido de forma expressiva.

O gráfico 2 representa o percentual da população adulta que já realizou alguma compra online em países com diversos níveis de desenvolvimento econômico e social.

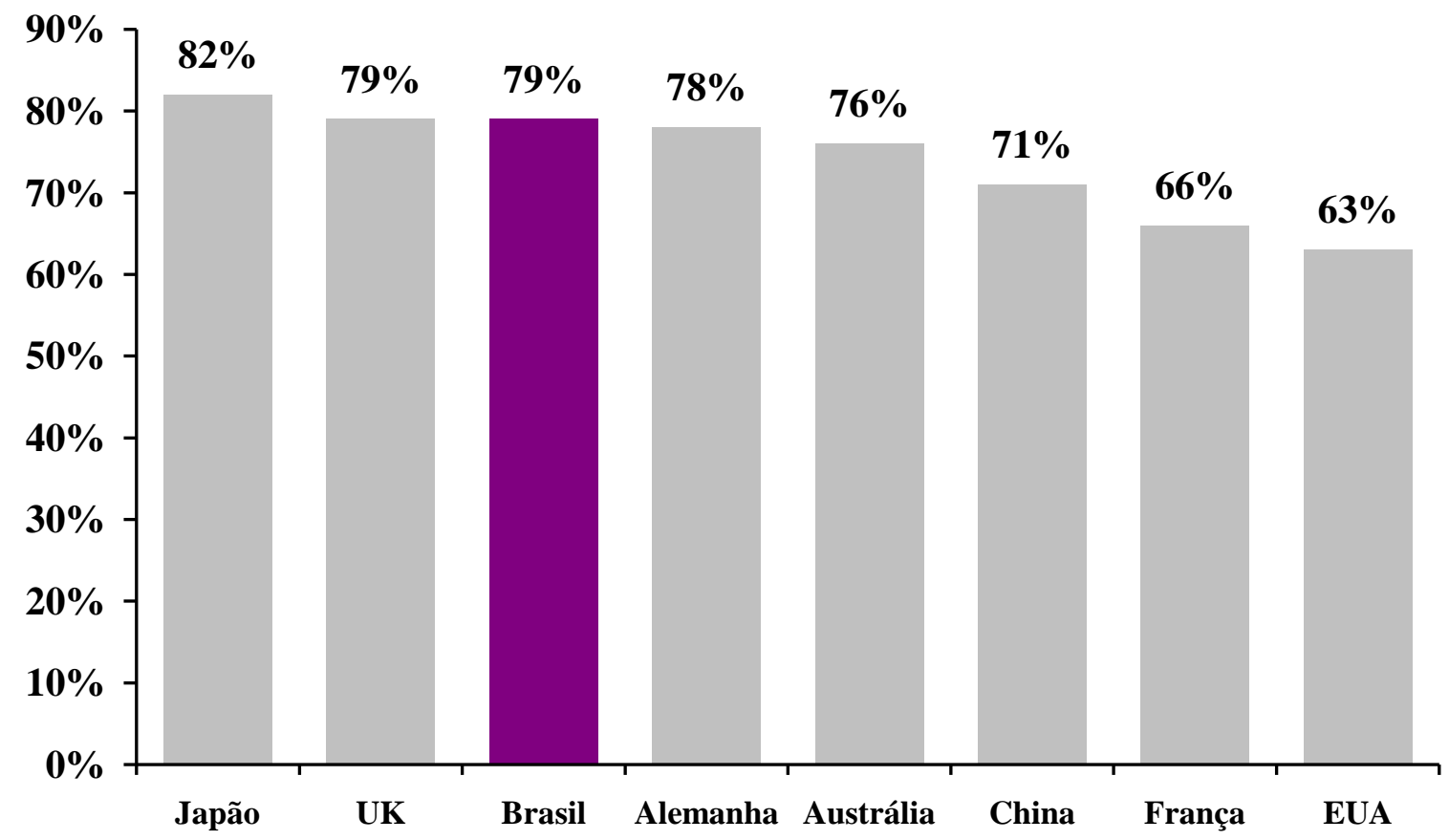

Gráfico 2 - Usuários de Internet que realizaram compras online em relação ao total da base de usuários FONTE: Symantec, Norton Online Living Report, 13 de Fevereiro de 2008 - Usuário com mais de 18 anos que já realizaram compra online $(n=4,687)$.

É interessante notar que no caso particular do Brasil, em que $79 \%$ dos usuários adultos de Internet já realizaram compra online, a taxa em relação ao total de usuários da rede é comparável a de países mais desenvolvidos socialmente e economicamente, e nos quais o uso da Internet e do comércio eletrônico foram disseminados muito antes. 
A natureza flexível da Internet e as possibilidades de interação a tornaram um meio interessante tanto para informar aos clientes sobre produtos e serviços quanto para fomentar transações para empresas dos mais diversos portes e setores de atuação.

Com o crescimento de sua importância econômica, o uso da rede com propósitos comerciais tem sido estudado na academia em diversos aspectos. Iniciando pela conceituação do que é o comércio eletrônico, Bloch et al (1996) apontavam que comércio eletrônico seria o suporte para qualquer natureza de transação que utilize uma infraestrutura digital, podendo ser empregado em todas as fases de uma relação de compra por parte do comprador. Analogamente, Albertin (2000) define comércio eletrônico como sendo a realização de toda a cadeia de valor dos processos de negócios em um ambiente eletrônico.

Outros autores concentraram esforços na classificação dos websites com objetivos comerciais de acordo com os conteúdos e serviços oferecidos aos usuários. Hoffman et al (1995) foram alguns dos pioneiros nesta linha, classificando os websites em seis categorias: online storefront, presença na Internet, conteúdo, agregador de compra, site de incentivo comercial e agente de busca. Concentrando-se em lojas online, Spiller e Lohse (1997) delimitaram cinco categorias: superstores, lojas promocionais, lojas de vendas, lojas de uma página e listagens de produtos.

Posteriormente, uma visão alternativa foi dada por Telles (2005), que indicou os diferentes estágios dos sites online de acordo com seu fim. Para os sites que atuam unicamente para divulgação de informações institucionais e dos produtos da empresa, o autor classifica como presença na Internet.

Telles (2005) observou ainda que sites de interação seriam aqueles que passam a incorporar interatividade por meio de consultas (formulários, registro de informações, consultas a bancos de dados, etc.).

Sites de transação seriam os que permitem a realização de transferência eletrônica de informações econômicas concedendo a realização de transações pela Internet; e por fim, o autor classifica como de "integração" os sites que permitem automatização e integração eletrônica de processos internos de uma companhia com o de seus clientes e parceiros por meio da Internet (TELLES, 2005). 
Em uma perspectiva diferente, baseada no conteúdo e design dos websites, um trabalho desenvolvido por Huizingh (2000) propôs a categorização dos sites comerciais voltados ao consumidor final com base nestes elementos, dada a importância que a facilidade de acessar as informações e navegar pelos conteúdos do site representam no processo de compra pela rede.

Ainda, segundo Huizingh (2000), o conteúdo refere-se primariamente às informações, recursos ou serviços oferecidos no website, enquanto as características de design estão relacionadas à disposição dos elementos na página, ao fluxo de navegação, e à apresentação dos produtos.

Evidentemente, a estratégia de conteúdo e design a ser adotada pela empresa varejista varia fundamentalmente em função do tipo de produto ou serviço ofertado e do público-alvo almejado pela empresa.

Brassington e Pettitt (1997) ressaltam que, tendo em vista que o processo de compra acontece em uma sequência de etapas, a busca de informações e a avaliação das informações coletadas desempenham papel preponderante dentro da delimitação do escopo de compra do consumidor.

Neste cenário, a diminuição dos custos de busca de informações proporcionada pela Internet um dos principais benefícios do uso da rede como fonte de informação no processo de compra - desempenha decisivo papel no aumento da conversão de usuários navegando no site em vendas efetivas (BAKOS, 1995).

Outra importante arma deste meio é que o dinamismo, na coleta de informações dos usuários enquanto navegam, permite que sites de e-commerce coletem informações em tempo real de quais produtos ou informações estão sendo requeridas pelos usuários, e assim, as lojas podem prover os usuários com informações de produto mais adequados aos interesses do consumidor ou produtos complementares, catalisando a geração de vendas e aumentando as chances de que os usuários passem a gastar um valor maior em cada compra. 
Dentro desta visão, Hutt e Speh (2001) apontam que a eficiência das ferramentas do comércio eletrônico pode ser aplicada em quase todas as fases do processo de compra pela Internet, com o efeito de criar novas demandas ou de tornar mais eficiente a maioria dos processos de venda.

Embora o crescimento do comércio eletrônico seja vertiginoso ao longo dos últimos anos em todo o mundo, e haja constantes investimento em pesquisas e no desenvolvimento de ferramentas mais inteligentes para a captação e análise das informações de navegação dos usuários, entender o comportamento do consumidor dentro deste ambiente de uma forma geral, e especificamente seus elementos motivadores e inibidores de compra que levam consumidores a optar pelo ambiente online ou pelas lojas físicas, continua sendo um dos principais desafios dos profissionais de marketing no entendimento e evolução dos processos de negócios das operações do varejo. 


\section{O PROBLEMA DE PESQUISA}

\subsection{Delimitação do problema de pesquisa}

O relatório Global Online Retailing (ERNEST \& YOUNG, 2001) aponta que mais da metade dos entrevistados passou a ir menos às lojas físicas em função das compras online. Nada mais natural então que tanto a academia quanto as próprias empresas varejistas tentem entender quais as variáveis e elementos de maior importância no incremento ou diminuição da atividade de compra em ambiente online.

Desta forma, ampliar o conhecimento sobre os elementos motivadores e inibidores do comportamento de compra na Internet e identificar padrões e oportunidades de atuação visando especificamente uma melhora na experiência de aquisição de bens e serviços neste meio é o foco principal do presente trabalho.

\subsection{Objetivo geral}

Analisar os elementos motivadores e inibidores que interferem no processo de decisão no comportamento de compra nas lojas de varejo pela Internet.

\subsection{Objetivos específicos}

Os objetivos específicos desta dissertação são:

- Identificar os principais elementos motivadores e quais os principais elementos inibidores da compra online;

- Identificar se há relação entre a experiência no uso da Internet e a frequência de compra online; 
- Identificar se há a existência de relação entre a satisfação com as compras anteriores pela Internet e a intenção de compra futura pelo meio;

- Determinar os principais dados demográficos do comprador online. 


\section{A INTERNET E O VAREJO}

\subsection{A importância da Internet no contexto do varejo brasileiro}

A Internet é considerada por diversos autores uma das mais significativas evoluções na forma como o homem acessa, produz e troca informações. Embora em ritmos diferentes, o aumento da penetração e do acesso à rede mundial de computadores cresce de forma acelerada e ininterrupta desde que saiu dos meios acadêmicos e militares e passou a ter aplicação para a sociedade civil (BOONE, HURTZ, 1998; LAN, 1999; LIENTZ, REA, 2001; KOTLER, 2003).

Com a possibilidade de enviar e receber informações em tempo real em praticamente qualquer ponto do planeta, a comunicação interpessoal passou por um intenso processo de catalisação, que, por sua vez, acarretou enormes mudanças na forma como as pessoas encontram novos fornecedores, buscam informações sobre produtos e serviços, tomam decisões de compra e investimentos, controlam tempos e etapas de entrega e avaliam níveis de serviço (LIENTZ, REA, 2001).

Como consequência, este cenário de grande efervescência econômica, social e cultural proporcionado pelo advento da rede também acabou resultando em um substancial incremento na competição entre as empresas (DRUCKER, 1999).

Especificamente dentro do segmento de varejo, as perspectivas de crescimento dos negócios associados ao comércio eletrônico na Internet vinham exatamente ao encontro dos desafios encontrados pelas empresas estabelecidas no Brasil. Tomando a definição de Levy e Weitz (1995), de que o varejo é o elo que permite conectar as pontas da cadeia de valor dos produtos, unindo os fabricantes e consumidores em um processo de fomento da troca entre os demais elos envolvidos, é fácil imaginar como a introdução de uma nova tecnologia de conexão que aumente a troca de informações entre as partes poderia impactar fortemente o equilíbrio e a própria dinâmica das relações entre estas mesmas partes. 
Como visto anteriormente pelos números de crescimento no Brasil, o comércio eletrônico vem se destacando como uma das principais formas emergentes de varejo na atualidade e pode representar uma grande oportunidade de aumento de receitas de vendas destas empresas. $\mathrm{Na}$ visão de Evans (1996), a Internet poderia até mesmo se converter em uma forma completamente nova de varejo, usurpando o tradicional domínio dos pontos de venda fisicamente estabelecidos. Uma outra visão sobre o assunto é dada por Hazel (1996), que coloca o papel da Internet como um suporte às atividades de marketing já estabelecidas para as empresas do setor.

Independente da visão de qual papel a Internet poderia ocupar dentro da atividade das empresas varejistas - o quanto profundo em relação ao impacto exercido na operação previamente estabelecida - a necessidade de encontrar novas ferramentas que pudessem favorecer competitivamente a atuação dentro deste mercado era vista como premente pelo mercado como um todo.

O fato é de que o potencial de aceleração e transformação da dinâmica de vendas do varejo pela Internet não pode ser desprezado por redes de qualquer porte (ARNOLD et al, 2007).

Operando em um setor cada vez mais competitivo, que recebia a entrada de diversos novos competidores de porte global, que conjugavam alto poder de negociação com fornecedores e fácil acesso às linhas de financiamento internacionais com custos bem mais baixos, o varejo brasileiro rapidamente percebeu que ajustes e ganhos de eficiência operacionais tornariam-se elementos-chave na manutenção de uma posição competitiva interessante e, em determinados casos, poderiam representar até mesmo a sobrevivência do negócio.

Angelo e Siqueira (2003) ressaltam que, com esta necessidade de mudança e ajuste à nova realidade de mercado, as operações de compra, movimentação e venda - que são a essência do negócio do varejo - voltaram a ser tratadas como o elemento fundamental de atenção das empresas do segmento.

Tendo como ponto de partida a retomada do foco de desenvolvimento corporativo na essência da atividade varejista, o objetivo final de um processo de melhoria de eficiência varejista culminaria, em última instância, em uma aproximação mais efetiva entre fabricantes e 
consumidores, fomentando as transações comerciais entre as duas partes com os menores custos possíveis, e proporcionando uma experiência de aquisição satisfatória por parte do usuário que estimulasse a repetição da compra (PORTER, 2001).

Ainda, de acordo com Porter (2001), uma das formas de se obter vantagens em eficiência operacional é exatamente o uso de melhores tecnologias; aqui entendidas tanto no sentido do desenvolvimento de técnicas próprias mais eficientes de realização de negócios ou do uso da tecnologia da informação para reduzir custos de operação e aumentar a geração de receita. A tecnologia pode ser aplicada aos negócios do varejo de diversas formas para maximização da eficiência operacional. Leilão reverso para fornecimento de produtos, integração dos sistemas de tecnologia envolvidos na cadeia de suprimentos, controle de estoques, atualização de preços são algumas das opções mais utilizadas, entre outras. Considerando-se especificamente seu uso para o aumento de vendas, uma das formas mais significativas e efetivas é exatamente o comércio eletrônico.

O comércio eletrônico na venda para clientes finais (B2C) configurou-se em uma das principais oportunidades identificadas pelas empresas varejistas para incrementar suas vendas sem a necessidade de grandes investimentos.

Diversos fatores que favorecem o uso desta tecnologia na geração de novos negócios podem ser apontados. Podemos destacar, por exemplo, a diminuição de formação de estoques, a menor necessidade de movimentação de materiais armazenados, a redução de intermediários no processo de vendas com a consequente oportunidade de incremento nas margens de vendas, e muitos outros. Contudo, em particular, destacam-se três aspectos que são os mais citados e pesquisados na literatura da área: o aumento do gasto médio dos clientes; a expansão da cobertura geográfica; e a ampliação do sortimento de produtos com diminuição de custos para geração de vendas.

\subsubsection{Aumento da receita total e do gasto médio dos clientes}

Hart et al (2000) colocam que a comparação de preços entre diferentes lojas acaba sendo amplamente facilitada pela Internet e, por consequência, requer que as lojas trabalhem com margens menores na operação online. 
Por outro lado, pela própria natureza da sua tecnologia, em um ambiente de compra online o comportamento do usuário pode ser registrado dinamicamente em todas as etapas de navegação e avaliação dos produtos. Desde as buscas por categorias, acesso às páginas contendo informações, leitura de avaliações de outros clientes, até a sequência de observação de páginas durante o processo (GLOOR, 2001).

Todos estes elementos da navegação podem ser usados em tempo real para estabelecer correlações e padrões de comportamento de compra, dando subsídios para as lojas virtuais disporem os produtos no site e oferecerem produtos adicionais com incomparavelmente mais eficiência e personalização do que acontece em uma loja física (LIENTZ, REA, 2001).

Lientz e Rea (2001) ainda mencionam que com isto os clientes podem receber uma ampla gama de benefícios em termos de seleção, escolha, facilidade de pedido, retorno, cancelamento e outras transações, estimulando a compra online.

No fluxo de navegação do site, a loja pode exibir a princípio produtos que o internauta tenha demonstrado interesse anteriormente, consultando, por exemplo, preços ou características de bens daquela categoria de produtos.

Estas informações são coletadas dinamicamente e gravadas no computador do usuário por meio de cookies, permitindo que a loja virtual também faça recomendações de produtos que possam interessar aos clientes, baseado no histórico de compras do próprio usuário ou de outras pessoas que apresentaram padrões de compra parecidos (KELLY, 2004).

Desta forma, com o uso da tecnologia, as empresas varejistas conseguem explorar melhor o potencial de compra de seus clientes oferecendo produtos mais pertinentes aos seus desejos e interesses, e maximizar o gasto médio oferecendo versões mais sofisticadas dos produtos de interesse e associando produtos complementares à compra de forma automatizada, em um movimento bem mais difícil de ser realizado em um ambiente não-virtual.

Outras características que reforçam o aumento do gasto médio dos clientes estão associadas ao tipo de processo de compra diretamente associado ao online. 
Entre outros fatores, o favorecimento da comparação entre diferentes produtos e a impossibilidade da gratificação imediata estimulam um processo de compra de maior envolvimento, o que em muitas categorias significa produtos de maior sofisticação fabril, com detalhes e características específicas (PETTY et al, 1983).

Como resultado desta característica, o preço médio de compra acaba sendo normalmente mais elevado do que em lojas físicas.

\subsubsection{Expansão da cobertura geográfica}

Além do gerenciamento e estimulação dos usuários em diferentes frentes, o ambiente online permite que empresas de varejo cubram áreas geográficas que não seriam viáveis economicamente por meio da instalação de uma unidade física (GLOOR, 2001).

Potencialmente, o alcance de uma loja virtual abrange todo o território nacional e pode até mesmo ser global (desconsiderando-se barreiras linguísticas e logísticas), expandindo o público-alvo e, também, a concorrência da empresa para muito além das unidades de vendas fisicamente estabelecidas. Drucker (1999) ressalta que uma das consequências do impacto do comércio eletrônico é que toda empresa deve tornar-se competitiva em nível global, ainda que fabrique ou venda apenas em um mercado local ou regional.

Slywotzky e Morrison (2000) observam a possibilidade de alcançar novos conjuntos de consumidores - como aqueles distantes geograficamente - conectando a empresa com seus clientes em locais remotos da cadeia de valor a um baixo custo como um dos principais benefícios da venda por comércio eletrônico.

Embora outros custos associados à presença em um determinado mercado se mantenham (como, por exemplo, impostos, logística, comunicação, etc.), a opção de explorar o mercado consumidor de uma região sem que haja a necessidade de estabelecer unidades físicas representa um aumento do público potencial do varejo a um custo significativamente menor.

Considerando particularmente os clientes atraídos ao website do varejista por meio de ações e campanhas realizadas no próprio ambiente online, pode-se considerar que a barreira regional 
para comunicação da empresa não exerce um efeito restritivo ao aumento do público (DRUCKER, 1999).

Outra característica já disseminada na compra pela Internet que favorece esta expansão geográfica obtida pela Web é a transferência dos custos de distribuição para o próprio consumidor, reduzindo potenciais aumentos de custos pela distância do mercado consumidor atingido pela venda na Internet dos centros de distribuições em regiões distantes (ANDERSON, 2006).

Anderson (2006) adiciona que com os custos de entrega pagos pelo próprio consumidor no ato da compra, o custo marginal de venda de um determinado produto para um usuário situado a milhares de quilômetros da central de distribuição da empresa é essencialmente o mesmo de um usuário que está a poucos quilômetros de distância. Com isto, a empresa amplia sua área de cobertura e consegue gerar negócios com consumidores que normalmente não teriam acesso a seus produtos pelos meios tradicionais, sem que isto venha a acarretar altos custos logísticos.

Acordos com empresas especializadas em logística de entrega de produtos garante ao varejista capilaridade de distribuição para conseguir atingir mesmo os mais distantes rincões a partir da mesma central de distribuição que abastece os principais centros consumidores da empresa.

Ainda que haja alguma restrição de operação de vendas em uma determinada região (por exemplo, por falta de acordo com uma empresa de distribuição que atenda a região específica, ou por barreiras tarifárias) a grande maioria dos websites e ferramentas de busca permitem restringir a exibição de anúncios do varejista apenas a clientes situados em uma macro-região, diminuindo a dispersão geográfica da comunicação da empresa.

\subsubsection{Maior sortimento de produtos e diminuição dos custos de geração de vendas}

Os custos associados à venda no varejo podem ser classificados como fixos ou variáveis. De forma geral, os fixos estão tradicionalmente associados à estrutura perene montada pela empresa como forma de exercer sua atividade de venda; já os variáveis são os que dependem 
diretamente do esforço de vendas despendido para a realização de cada venda individualmente (AAKER, 2001).

Salários, aluguéis, propaganda e promoção, suprimentos, depreciação, seguros, taxas legais, impostos, licenças e despesas diversas são alguns exemplos de custos fixos e variáveis recorrentes para a manutenção de uma loja de varejo (MASON, MAYER, EZELL, 1998).

Um dos principais geradores de custos para as empresas varejistas é a manutenção de uma ampla estrutura de venda em cada uma de suas unidades. Custos como locação do espaço, manutenção, reposição, recursos humanos, e diversos outros determinam a necessidade de uma priorização de produtos nas prateleiras que concentre a oferta nos bens de maior demanda popular (AAKER, 2001).

Berman e Evans (1998) apontam que a qualidade da manutenção da loja afeta a percepção que o consumidor tem do varejista e, em última instância, sua própria disposição em comprar na loja. O objetivo desta estratégia é maximizar a rentabilidade de cada espaço de vendas disponível na loja, aumentando o giro financeiro e diluindo os altos custos fixos da estrutura da loja.

Todavia, quando a operação da loja varejista ocorre no ambiente online, todo este universo de produtos que apresenta uma quantidade de vendas mais baixa, e que é desprezado no varejo tradicional, passa a poder ser ofertado sem impactar os custos e nem diminuir a rentabilidade da operação (ANDERSON, 2006).

Considerando-se que o custo de armazenamento da informação sobre os produtos é desprezível, exibi-lo aos usuários representa exatamente a mesma relação de oportunidade que um produto mainstream, ou seja, um produto popular, que apresente vendas em grandes volumes ou quantidades. A loja, sem a necessidade de manter estes produtos em estoque em um centro de distribuição, pode encomendá-los sob demanda aos fabricantes apenas após a concretização da venda, e assim garantir a melhor margem nas vendas (GLADWELL, 2002).

Se o produto em questão é digital, como um arquivo de música ou filme que pode ser disponibilizado para download, por exemplo, a loja pode ainda comercializá-los e entregá-los exclusivamente no meio online, possibilitando redução dos seus custos de estocagem a níveis 
extremamente baixos (apenas o custo de armazenagem do arquivo-fonte do produto) e o custo de transferência dos dados, e trazendo receita adicional de produtos que normalmente não seriam vendidos em sua estrutura de pontos de venda tradicional.

Este efeito - conhecido como cauda longa - embora não seja exclusivo das vendas pela Internet, certamente acontece em sua plenitude no ambiente online, uma vez que ferramentas de navegação, filtros e sistemas de buscas favorecem que os consumidores encontrem produtos de nicho neste meio, e desta forma, satisfaçam necessidades e desejos específicos que seriam bem mais trabalhos no mundo não-virtual (ANDERSON, 2006; ARNOLD et al, 2007).

A venda de produtos da cauda longa, difíceis de serem aproveitados no varejo tradicional, mas interessantes no ambiente online, podem representar mais de $20 \%$ das vendas totais de uma loja virtual, constituindo uma importante forma de incremento de receita sem onerar a operação de vendas ou comprometer espaço de gôndola nas lojas físicas (ANDERSON, 2006).

\subsection{Razões para opção por não desenvolver uma estratégia online}

Ainda que a importância da rede seja crescente para os negócios, fatores como a alta velocidade das mudanças, a falta de conhecimento ou a seleção de estratégias inadequadas de exploração da rede tornam inúteis muitos esforços realizados por empresas que tentam implementar uma estratégia online, às vezes resultando em grandes perdas financeiras.

De acordo com Toledo (2003), embora a Internet tenha se consolidado como um fenômeno que definitivamente não pode ser ignorado, várias empresas, por não estarem adequadamente preparadas, adotam soluções tecnologicamente avançadas, mas estrategicamente estéreis, acarretando perda de eficiência nos processos gerenciais e ineficácia na consecução dos objetivos.

Para Lan (1999), as empresas que entram na rede procuram acompanhar o desenvolvimento tecnológico, porém nem sempre o fazem de modo estruturado, de forma que sua adesão é feita 
por vezes tão rapidamente que, frequentemente, não existe a preocupação com 0 planejamento, gerando gastos excessivos que não darão retorno, nem no curto, nem no longo prazo.

Na perspectiva da empresa, um dilema recorrente é a sobrevivência, ou não, apenas com as lojas físicas. De acordo com Toledo e Crescitelli (2004), um fator importante é o tamanho do segmento, ou seja, o número de compradores que utiliza o varejo eletrônico não pode ser pequeno o suficiente para inviabilizar economicamente a operação. Uma quantidade de iniciantes muito pequena pode inibir a viabilidade econômica do negócio, uma vez que a taxa de crescimento da demanda não é capaz de propiciar a rentabilidade necessária para a manutenção do negócio.

Apesar da incorporação da Internet ao processo de comercialização de quase todo tipo de empresa, o aproveitamento das oportunidades requer altos investimentos, que não se restringem à adoção da tecnologia necessária. O maior obstáculo está na necessidade da empresa repensar seus processos de negócios, principalmente no que se refere à interação eletrônica com seus clientes.

Por mais que as oportunidades de ganho pareçam tentadoras, as empresas precisam conter a euforia antes de se atirar ao mundo virtual, questionando como a implantação do comércio eletrônico poderá colaborar com os resultados da operação da empresa.

Aderir ao comércio eletrônico porque é uma tendência pode ser um desperdício de recursos, além de colocar em risco a própria imagem da empresa mesmo em suas atividades no mundo físico. Deve-se considerar o investimento em uma relação com os clientes através da interatividade, criar uma estrutura de logística para entrega, atualizar constantemente o conteúdo e cumprir prazos prometidos.

De acordo com Lan (1999), algumas preocupações que deveriam permear empresas que querem adotar o varejo virtual são: a atratividade da página para o usuário (em média são consumidores com alto nível cultural e grande poder econômico); a integração entre as ações de marketing realizadas offline e as realizadas na Internet; e a atualização das informações disponíveis no website. Todas estas questões requerem o investimento contínuo de recursos, e a empresa precisa ponderar se é um investimento que trará um nível adequado de retorno. 
Outra questão para a empresa é a necessidade de conhecimento prévio de hábitos de consumo dos internautas, supondo-se que os hábitos dos seus clientes já são conhecidos. É indispensável entender como o consumidor tem acesso à Internet e se os produtos ofertados são adequados ao perfil do consumidor que usa a rede. Uma consideração interessante referese ao desejo da empresa de sofisticar seu público-alvo, uma vez que a Internet apresenta-se como um meio para atender consumidores cada vez mais exigentes, bem informados e interessados em serviços novos e personalizados (SIQUEIRA, 2004).

A adoção da Internet como uma estratégia comercial deve ser compatível com a estratégia geral da empresa e aceitável para seus consumidores. Em outras palavras, o desenvolvimento de uma estratégia online como complementação do varejo tradicional requer a convergência de dois fatores: consentimento dos consumidores e interesse das empresas (SIQUEIRA, 2004).

Em relação ao consentimento dos consumidores, para Siqueira (2004), há de se verificar se os consumidores aceitam ser direcionados para um meio virtual onde passariam a fazer suas compras. Caso os consumidores possuam pré-disposições contrárias ao comércio eletrônico, de nada adiantarão os esforços das empresas para levá-los a um website comercial.

Caso os consumidores estejam dispostos a receber o varejo virtual, será necessária a definição de novas práticas de marketing, já que, de acordo com Lan (1999), o público online é influenciado a comprar com base em informação objetiva e não pelas técnicas tradicionais de propaganda e persuasão.

Para Elliott e Speck (2005), os fatores que afetam as atitudes dos consumidores em relação a um website são: suas características (facilidade de uso, informação sobre o produto, entretenimento, confiança, serviço de atendimento ao consumidor e aceitação), o envolvimento do consumidor com o produto e a experiência prévia com compras online.

Geralmente, os consumidores não compram produtos de conveniência e não duráveis pela Internet, uma vez que eles não estão dispostos a dispender tempo e dinheiro para adquiri-los (conexão, busca, processo de compra, taxa de entrega, tempo de entrega, etc.), sendo que serão totalmente consumidos após um ou poucos usos, e a recompra é frequente (LINDEN, 2004). 
Alguns comentários extraídos da pesquisa de Linden (2004) sobre a adoção do varejo online para supermercados explicitam alguns dos fatores de indisposição dos consumidores para adoção da compra eletrônica no setor: "Gosto de pegar nos produtos, principalmente os altamente perecíveis", "Gosto de checar a validade dos produtos. Eles sempre mandam coisas velhas, perto do vencimento. Sempre compro produtos frescos, que ainda duram em minha casa", "Não acredito na viabilidade de fazer compras pela Internet, pois conheço muitas histórias de problemas e não quero me aborrecer com isso. Tenho medo de clonagem meu cartão de crédito. Não envio nenhuma informação pessoal através da Internet" e "Eu gosto de andar pelo supermercado em busca de lançamentos e promoções".

Ainda na perspectiva do consumidor, pode haver resistência às compras pela Internet por diversos fatores, como entendimento do processo como complicado (com a concepção das páginas seguindo uma distribuição confusa, ou com um projeto cuja aparência e navegação não agrade a maioria dos usuários) e indisposição para adotar a tecnologia necessária às compras online.

Segundo Porto (2000), uma nova tecnologia é mais rapidamente aceita quando oferece mais conveniência para o usuário do que a tecnologia que está sendo substituída, e em última instância, cabe aos consumidores a decisão de adotar ou não a nova forma de realizar transações. As novas tecnologias só irão mudar a demanda dos canais se elas solucionarem os antigos problemas dos canais de forma mais eficaz do que as soluções existentes.

Outros dois fatores limitadores frequentemente identificados na literatura sobre varejo online englobam desconfiança do consumidor em relação ao processo logístico e insegurança nas transações financeiras. Em relação à desconfiança, atribui-se a falta de integridade dos dados na Internet e a incapacidade de rastreamento das compras, resultando em um sentimento de receio e falta de confiança na entrega do produto comprado no prazo negociado. Em relação à insegurança nas transações, o receio reside principalmente na possibilidade de fraudes com cartões de crédito; fruto da percepção de perigo e fragilidade da segurança no envio das informações no momento da concretização da transação online.

Outras barreiras ao uso do varejo na Internet pelo consumidor foram descritas por Linden (2004), em uma pesquisa sobre a adoção do varejo virtual em supermercados, mas que 
merecem reflexão para outros setores. A primeira barreira trata da crença de que lançamentos e promoções só existem na loja. A maioria dos respondentes da pesquisa gosta de andar pela loja em busca de lançamentos e promoções, o que talvez seja uma barreira para o uso da Internet como meio de fazer compras de supermercado, devido à existência da ideia de que somente caminhando pela loja se encontram boas ofertas e novidades (LINDEN, 2004).

Diversas empresas varejistas têm trabalhado ao longo dos últimos anos em ações e promoções específicas e exclusivas para o meio online, como forma de reverter este quadro e tentar criar a percepção de igualdade de oportunidades e novidades exclusivas em ambos os ambientes tanto nas lojas físicas quanto nas virtuais. A segunda barreira refere-se à relação de experiência táctil, de pegar, ver e escolher os produtos. As pessoas não confiam em delegar esta tarefa, especialmente em relação a produtos alimentícios rapidamente perecíveis (LINDEN, 2004).

Particularmente nos casos em que a necessidade de interação pessoal ou experiência táctil com o produto é fator substancial no processo de compra, parte do valor de geração de vendas resultante da ação da Internet acontece no ponto de venda físico. Nestes casos, o usuário pode eventualmente começar o processo de coleta de informações sobre os produtos pela Internet, fazer a delimitação da lista de consideração, mas concluir a compra indo a uma loja fisicamente estabelecida, como forma de se esquivar de alguns dos fatores inibidores da compra online.

Segundo Chiagouris e Long (2007), uma integração adequada das atividades online e offline é crítica, já que a Internet influencia $22 \%$ das vendas offline. Neste sentido, a empresa que pretende adotar uma estratégia de varejo virtual deve refletir sobre os impactos dessa decisão na estratégia global da empresa.

Outro fator que deve ser levado em consideração na montagem de uma estrutura voltada para vendas online é que a rede possibilita uma comunicação em duas vias com o consumidor, portanto, a empresa deve estar preparada para responder todas as dúvidas, sugestões e reclamações dos usuários, no menor tempo possível.

Para Menon e Kahn (2002), existem muitas diferenças entre o varejo tradicional e o eletrônico que não podem ser ignoradas e que se traduzem em desvantagens no momento de se fazer 
compras pela Internet - por exemplo, o controle absolutamente grande dos consumidores sobre as informações que recebem, bem como os sites que eles acessam. No mundo físico, o cliente vê a loja e pode se sentir tentado a visitá-la, já o site na Internet depende da memorização de um endereço ou de mecanismos de busca para saber de sua existência (TOLEDO, 2003).

Boone e Kurtz (1998) pontuam que um website é capaz de construir lealdade, economizar recursos de empresas e clientes, tornar os processos de venda mais rápidos e incrementar os lucros, desde que seja um canal eficaz. Para tal, é necessário o investimento em uma estratégia integrada entre as áreas e mudanças no mix de marketing, no intuito de adequar a oferta online.

Toledo e Crescitelli (2004) ressaltam que disponibilizar vendas pela Internet é estrategicamente uma opção válida, mas, por si só, não garante o estabelecimento de vantagem competitiva sustentável. Esta estratégia deve vir associada a outras práticas, como programas de relacionamento ou prestação de serviços diferenciados.

Em suma, desenvolver uma estratégia de utilização da Internet, como canal de vendas, comunicação e relacionamento com os clientes, exerce impacto na operação da empresa como um todo; e como tal, deve ser planejada a tornar-se um instrumento efetivo de ampliação e desenvolvimento de novos negócios. 


\section{COMPORTAMENTO DO CONSUMIDOR}

Da mesma forma que a revolução industrial mudou radicalmente a natureza do trabalho, criou enorme riqueza e trouxe novos estilos de vida. O surgimento da Internet como canal de compras proporciona uma série de benefícios aos consumidores - sendo talvez o mais expressivo a conveniência de compra - que também tem o potencial de mudar de forma dramática as relações de consumo entre empresas e clientes.

$\mathrm{O}$ crescimento que vem sendo verificado no número de compradores online no Brasil ao longo dos últimos anos reflete exatamente a importância do papel que a Internet tem representado no comércio. O gráfico 3 demonstra a evolução do número de compradores online no país.

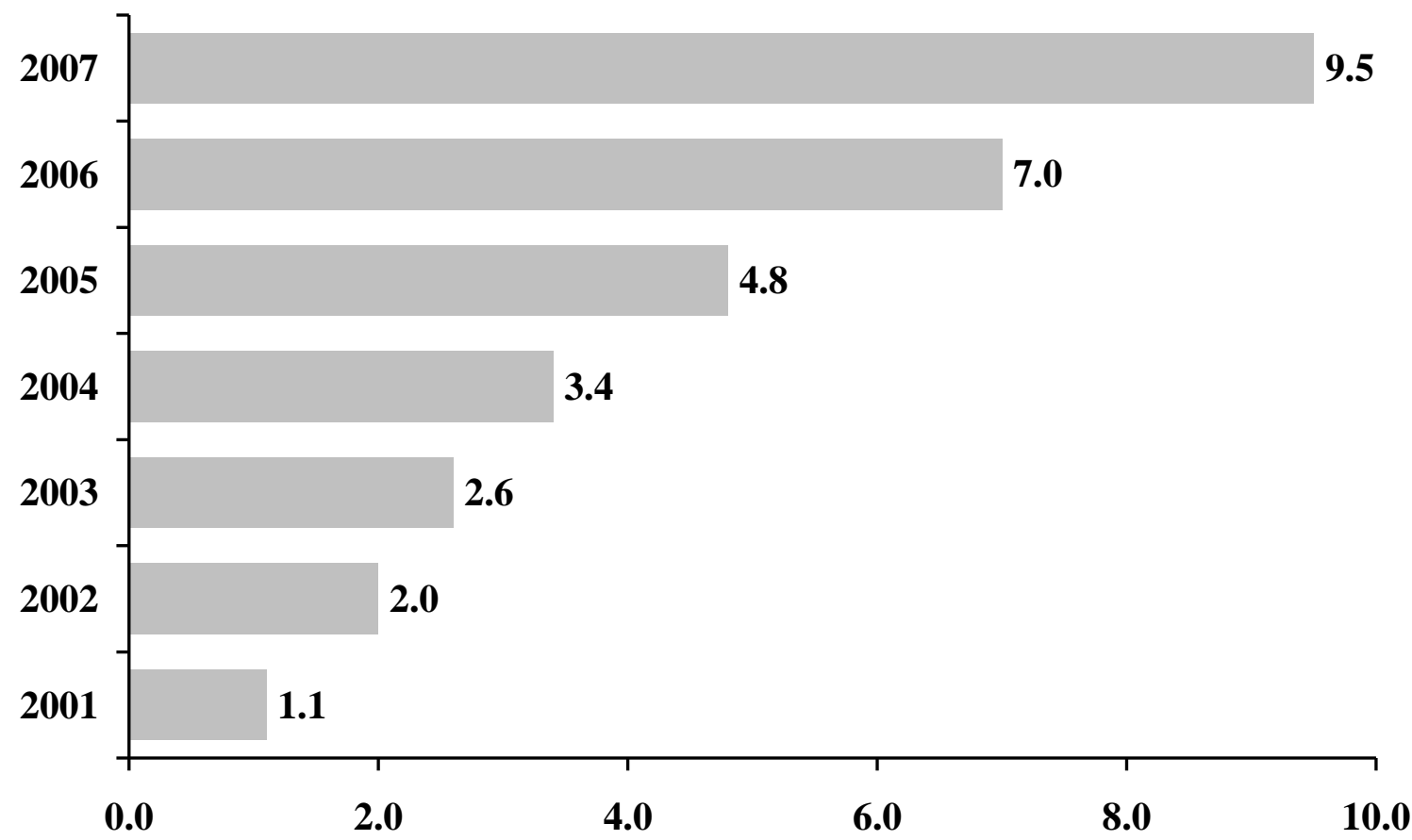

Gráfico 3 - Compradores online* no Brasil - 2001 a 2007 (em milhões) Nota: *pessoas que realizaram pelo menos uma compra desde 2000. FONTE: e-bit, estudo Web Shoppers, 17 edição, Março 2008.

E não apenas o número de compradores online vem aumentando substancialmente ano após ano, como também o gasto médio que é realizado por estes consumidores. 
O gráfico 4 apresenta a evolução do gasto médio no país, de 2001 a 2008.

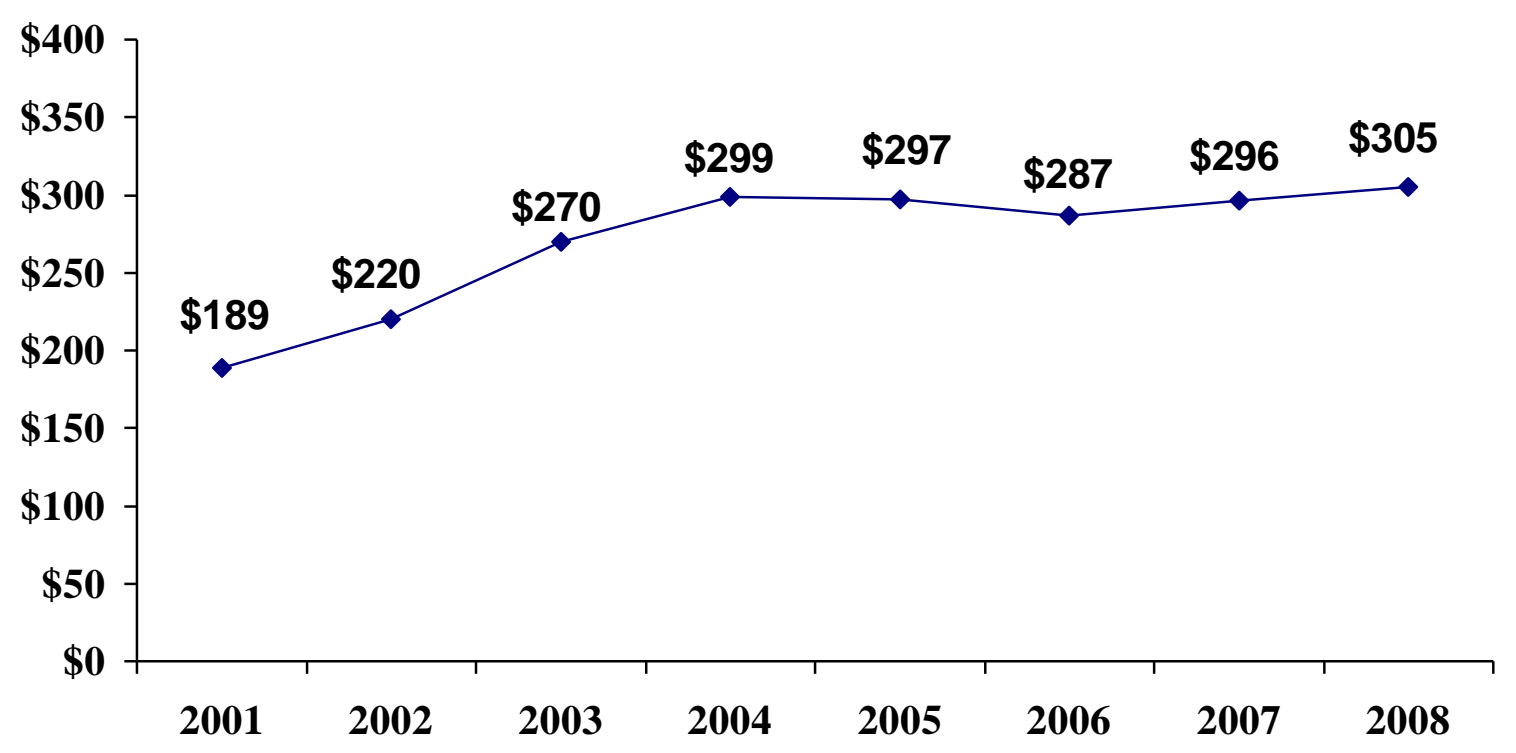

Gráfico 4 - Evolução do gasto médio em compras realizadas na Internet no Brasil - 2001 a 2008 FONTE: e-bit Informação. Período de Janeiro de 2001 a Junho de 2007.

O crescente aumento no gasto médio de compra dos consumidores brasileiros (em patamar muito superior ao aumento da inflação e da renda no período) mostra um aumento do conforto na realização nas transações pela Internet e a valorização das características que são próprias ao meio.

Além da facilidade de acesso às informações e ao acervo da loja desejada a partir de qualquer lugar com acesso à rede, uma série de características intrínsecas à compra, realizada online, distinguem o comportamento de compra do realizado em lojas fisicamente estabelecidas.

A disponibilidade de compra 24 horas por dia, a possibilidade de não necessitar de deslocamento, a facilidade de realizar uma pesquisa sobre produtos e seus preços, o nível de controle sobre o processo de compra são alguns dos motivadores e mediadores da atitude do consumidor em relação à compra online (LADEIRA, 2000).

A seguir são revisadas as principais etapas constituintes do processo de decisão de compra do consumidor nos quais a Internet age mais diretamente, e na sequência, os fatores motivadores e inibidores de compra à luz do comportamento de compra especificamente no meio online. 


\subsection{Processo de decisão do consumidor}

O processo de decisão de compra do consumidor representa a sequência esquemática de decisões tomadas desde o reconhecimento de uma necessidade até o final do processo de consumo de um produto/serviço comprado.

Durante este processo, uma série de forças internas e externas interagem e afetam como os consumidores pensam, avaliam e agem (BLACKWELL et al, 2005).

A abordagem predominante da sequência de ações componentes do processo de decisão do consumidor descreve o processo como uma sequência de aprendizado, processamento das informações coletadas, e tomada de decisão; divididas em etapas consecutivas: identificação do problema, busca de informações, avaliação das alternativas, decisão de compra e avaliação pós-compra (BOYD et al, 2002; BRASSINGTON, PETTITT, 2003; JOBBER, 2001; KOTLER, 2003).

No modelo posterior, desenvolvido por Engel, Kollat e Blackwell (apud BLACKWELL et al, 2005), 7 estágios são identificados para analisar como os indivíduos ordenam os fatos e as influências para tomar decisões que são lógicas e consistentes para eles. 


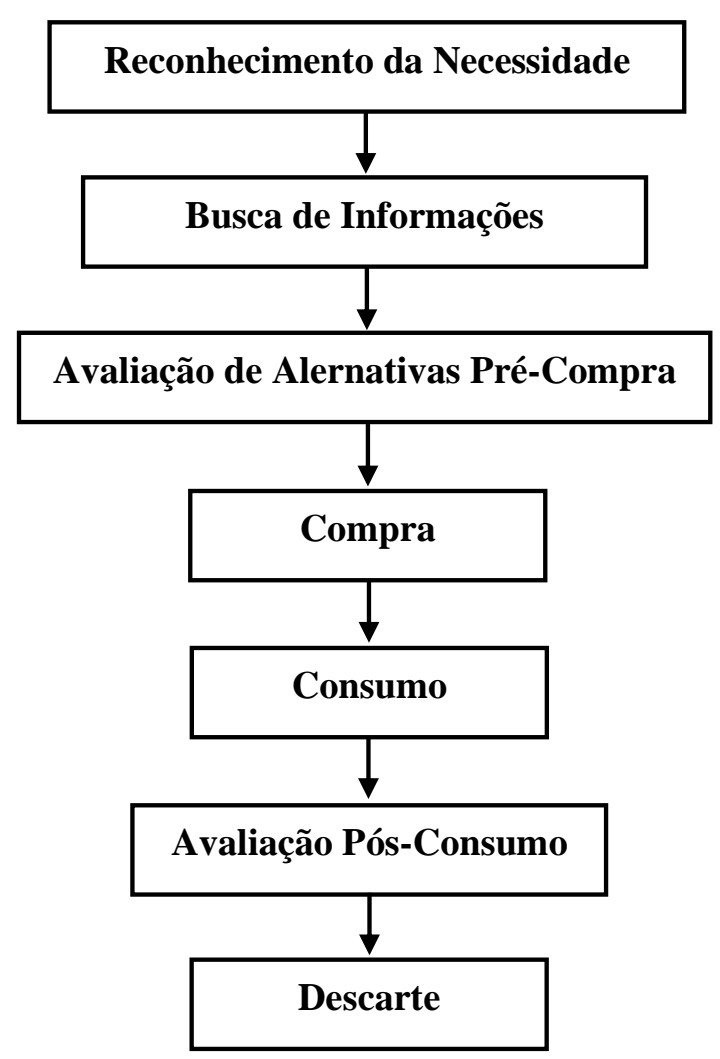

Figura 1 - Etapas da tomada de decisão dos consumidores para compra de bens e serviços FONTE: Adaptado de Blackwell et al (2005).

Considerando-se que dentro do processo de compra o papel da Internet no provimento de informação e na conexão entre usuários e varejistas seja particularmente mais ativo nas etapas de busca de informações, avaliação das alternativas pré-compra, e compra, uma análise específica dentro destas etapas será conduzida a seguir.

\subsubsection{Busca de informações}

Após reconhecer uma necessidade, os consumidores começam a buscar informações para satisfazer suas necessidades não atendidas. A busca pode ser interna, recuperando o conhecimento na memória, ou talvez, nas tendências genéticas; ou pode ser externa, coletando informações entre os pares, familiares e no mercado (BLACKWELL et al, 2005, p. 76).

A extensão e a profundidade da busca é determinada por diversas variáveis como personalidade, classe social, renda, tamanho da compra, envolvimento, experiências passadas, 
percepção da marca e satisfação dos consumidores (BLACKWEEL et al, 2005; PETTY et al, 1983).

Blackwell et al (2005) também ressaltam que a confiabilidade e qualidade da busca é proporcional à percepção do consumidor em relação ao conhecimento que ele detém sobre o produto a ser comprado e suas opções de escolha.

Nos casos em que julga ter nível de conhecimento suficiente sobre a compra, os consumidores usam prioritariamente seu conjunto de lembranças (busca interna), com as marcas e produtos armazenados em sua memória (BLACKWELL et al, 2005; MINOR, MOWEN, 2003).

Quando este conhecimento já armazenado é julgado insuficiente para a tomada de decisão, o consumidor parte para a busca externa de informações, visando justamente alcançar e definir melhores opções de consumo para aquela situação específica, ou ainda para oportunidades futuras de compra (BLACKWELL et al, 2005).

Exemplos de fontes externas podem ser amigos, familiares, líderes de opinião e mídia. Muitas destas influências vêm por meio do "boca-a-boca"; outras, de fontes de avaliação de produtos, como relatórios de consumidores e de indústria e governo ou notícias de mídias de massa (BLACKWELL et al, 2005).

Ao longo do levantamento de informações na busca externa, também são definidos critérios de avaliação e diferentes níveis de importância atribuídos a cada critério, de forma a permitir a comparação entre produtos com características diferentes e desenvolver um processo de maior racionalidade na atribuição de valores aos benefícios proporcionados por cada alternativa de compra (MINOR, MOWEN, 2003).

Desta forma, é possível aumentar o nível de racionalidade do processo de compra, potencialmente diminuindo a chance de que a compra venha a ser mal sucedida e possa provocar dissonância cognitiva no usuário; ou seja, o processo de tomada de decisão mais subsidiado por informações, estruturado, e racional, proporcionado pela Internet, potencialmente diminuiria a chance de que haja uma diferença entre a expectativa pré-compra e o atendimento das expectativas com o produto na avaliação pós-compra (dissonância cognitiva). 
Kotler e Keller (apud OLIVEIRA, 2007) apontam que a busca de informações com pessoas consideradas confiáveis, a preferência por marcas conhecidas e que concedam garantia e até mesmo a postergação da decisão de compra são maneiras que o consumidor tem para reduzir o risco.

A figura seguinte ilustra de forma esquemática o processo de busca de informações do consumidor para um determinado produto.

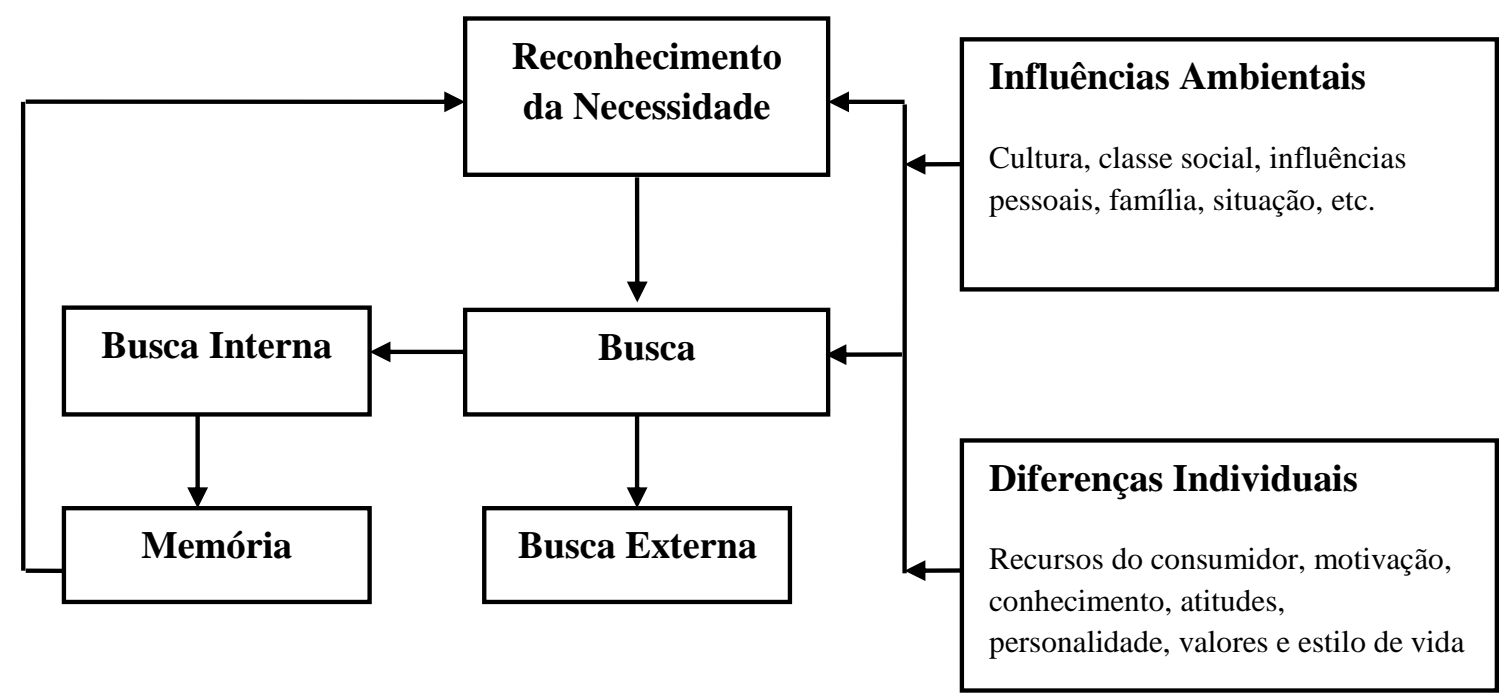

Figura 2 - Processo de busca de informações FONTE: Adaptado de Blackwell et al (2005).

Alguns pesquisadores indicam que como o varejo online diminui o custo de busca de informações de preço, acaba tornando os consumidores mais sensíveis a preço (MACMILLAN, MCGRATH, apud BLACKWELL et al, 2005).

Analogamente, Bakos (1995) considera a diminuição dos custos de busca por informações como um benefício fundamental do mercado eletrônico dentro do processo de compra, ocasionando um aumento na sensibilidade dos consumidores a preço.

No entanto, uma distinta visão é dada por outros estudos que têm mostrado que alterando o projeto do site, tornando mais fácil a busca de informações e a comparação de qualidade, os consumidores podem tornar-se menos sensíveis a preço pela priorização de outros fatores na 
análise global de compra, tendendo, por exemplo, a comprar mais produtos de qualidade (MERGENHAGEN, apud BLACKWELL et al, 2005).

De qualquer forma, ainda que varie bastante em cada caso, a extensão da busca externa está bastante relacionadas a alguns fatores.

\subsubsection{Relação entre benefícios e custos}

Ainda que a Internet tenha permitido uma intensa redução nos custos de busca de informações, os esforços percebidos no processo devem ser menores do que os benefícios recebidos em melhoria da qualidade do processo de compra proporcionados por estas informações adicionais recebidas (BLACKWELL et al, 2005).

Quando o custo de obtenção de informações adicionais para o processo de tomada de decisão é percebido como superior ao benefício em melhoria no resultado da compra, a busca externa por informações é cessada e as informações já coletadas passam a constituir o arcabouço referencial para a análise e processo de decisão (BLACKWELL et al, 2005).

\subsubsection{Percepção de Risco}

Quanto maior o nível de incerteza e risco percebido das consequências de uma compra mal feita (por haver excessivo dispêndio de recursos, comprometimento do uso do produto, tempo gasto em troca ou reparação do produto, etc.), maior a disposição do consumidor em investir tempo e esforços na coleta e processamento de informações que levem a um processo de decisão mais embasado e com maior qualidade (MINOR, MOWEN, 2003).

Shet et al (2001) também citam o risco percebido na compra do bem considerado como um fator de influência na busca por fontes externas. Quanto maior a percepção de risco envolvido na compra, maior tende a ser o número de fontes externas consideradas para a definição das opções consideradas.

Um importante aspecto a ser ponderado é que a percepção de risco não está necessariamente relacionada às características intrínsecas do produto, mas essencialmente à disposição do 
comprador em aceitar um nível maior ou menor de chance de haver problemas na compra daquele produto especificamente.

Perceber-se como tendo a responsabilidade pela atribuição da responsabilidade da compra e pela garantia da redução dos riscos associados a ela, influencia a disposição e o nível de esforço empreendido pelo consumidor no processo de compra do produto (FOLKES, 1984).

\subsubsection{Redução da dissonância cognitiva}

As expectativas pré-compra do consumidor não necessariamente acabam sendo confirmadas com o processo de avaliação pós-compra, o que a literatura de comportamento do consumidor classifica como dissonância cognitiva.

Em última instância, o objetivo - e a extensão - dos esforços empreendidos no processo de busca de informações pelo consumidor, visa a redução da possibilidade de surgimento de dissonâncias (GRISI, 2006).

Holloway (apud Grisi, 2006) aponta alguns fatores que favorecem o aparecimento de dissonâncias, a destacar:

a) Atração da alternativa rejeitada: quando o consumidor fica com a percepção de que a opção de produto rejeitada pudesse ser melhor do que a efetivamente comprada;

b) Fatores negativos na alternativa escolhida: ocorre quando o consumidor percebe, após a compra, características que não estão consonantes às imaginadas no momento précompra;

c) Número de alternativas: as alternativas para escolha são inúmeras que a escolha é dificultada. A opção pode ocorrer sem que haja garantia de que seja a mais correta;

d) Sobreposição de cognições: ofertas similares sobre vários aspectos ensejam decisões que são reconhecidas posteriormente como não completamente próprias;

e) Importância da cognição envolvida: falha de uma perfeita hierarquização da importância atribuída às características ou benefícios da oferta;

f) Persuasão positiva: a decisão é tomada sobre um aspecto relevante para a compra, mas não se pode garantir que este seja o aspecto de maior relevância. 
Grisi (2006) indica também que consumidores dissonantes podem se constituir, em um momento inicial, em alvos mais suscetíveis às comunicações de novos produtos ou a comunicação de novas marcas, estabelecendo uma importante oportunidade para os profissionais de marketing inserirem a mensagem de seus produtos em um momento em que o consumidor está mais propenso a recebê-la.

\subsubsection{Avaliação de alternativas pré-compra}

O estágio seguinte do processo de decisão do consumidor é avaliar as alternativas identificadas durante o processo de busca. Os consumidores comparam, contrastam e selecionam a partir de vários produtos e serviços (BLACKWELL et al, 2005).

Ainda, segundo Blackwell et al (2005), os consumidores comparam o que conhecem sobre diferentes produtos e marcas com o que consideram mais importante, e começam a estreitar o campo de alternativas antes de finalmente resolver efetivar a compra de uma delas.

Neste estágio, os consumidores empregam padrões e especificações definidas para a comparação dos diferentes produtos e marcas. A forma como os indivíduos avaliam suas escolhas é influenciada tanto pelas diferenças individuais quanto por variáveis ambientais, tendo como resultado um critério que traduz uma manifestação produto-específica dos valores, necessidades e estilos de vida dos indivíduos (BLACKWELL et al, 2005; MINOR, MOWEN, 2003).

Embora ainda alinhados com esta visão, Kotler e Keller (apud OLIVEIRA, 2007), por outro lado, afirmam que os modelos mais atuais de avaliação de alternativas de compra consideram que o processo ocorra predominantemente de maneira racional e consciente.

Blackwell et al (2005) apontam que alguns atributos considerados para a avaliação são salientes e outros determinantes. Os atributos salientes são os potencialmente mais importantes, e incluem, por exemplo, preço e confiabilidade, e tendem a variar menos entre as opções selecionadas para a lista de consideração. 
Já os determinantes são os que determinam qual marca ou loja será escolhida pelo consumidor, especialmente quando os produtos comparados são equivalentes (BLACKWELL et al, 2005).

Claramente, há uma série de fatores que afetam o processo de avaliação das alternativas e a efetivação da compra pelo comportamento do consumidor online.

Na sequência, um framework proposto por Kotler (2003) que capta as diversas forças atuantes no processo decisório da compra em ambiente virtual.

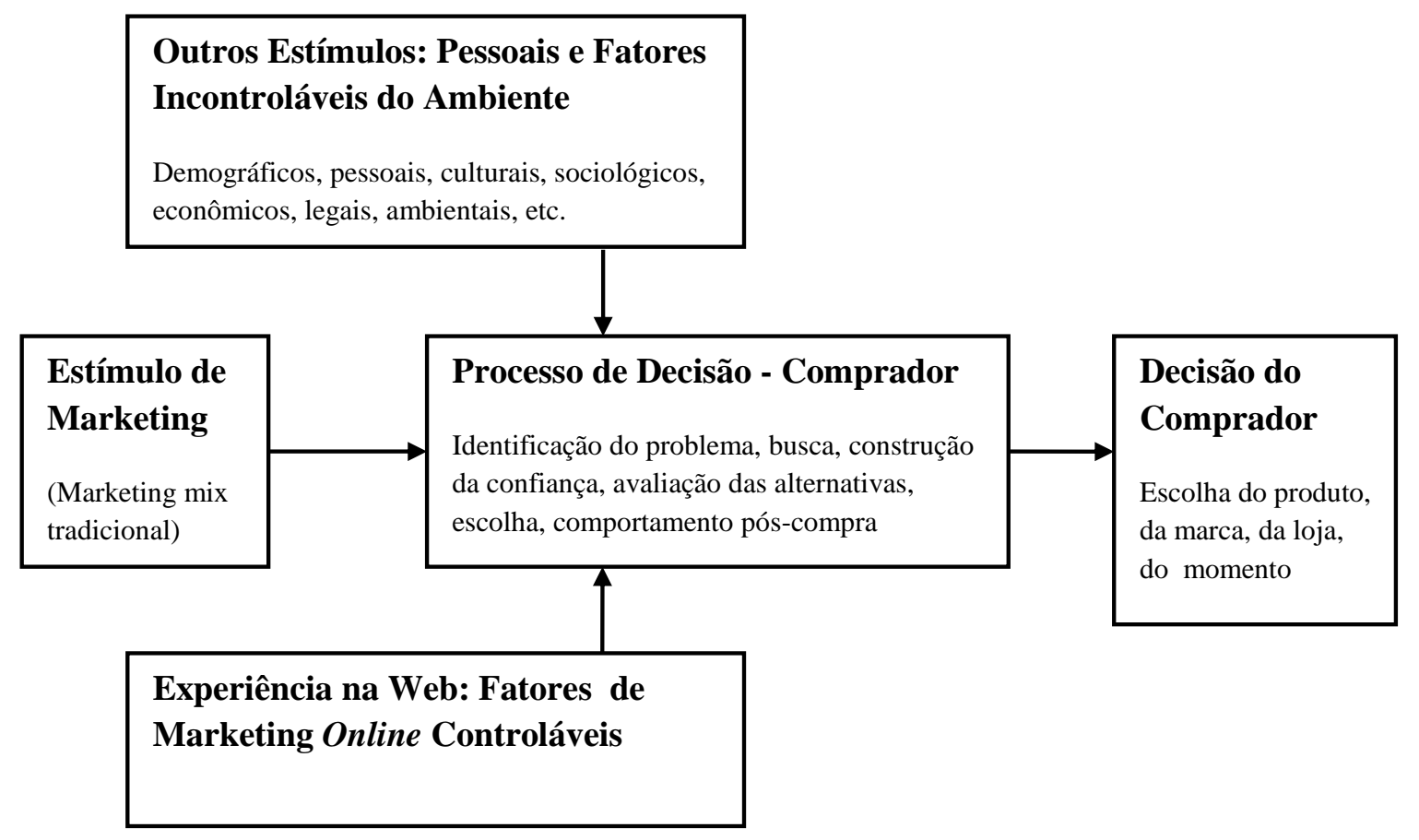

Figura 3 - Fatores que influenciam o comportamento do consumidor online FONTE: Adaptado de Kotler (2003).

Um outro significante aspecto de distinção é feito em relação ao nível de envolvimento do comprador com o produto em questão, que influencia diretamente a extensão do processo de busca por informações e a disposição de investimento de tempo e esforços na avaliação das alternativas de compra como forma de diminuir a possibilidade de dissonância cognitiva póscompra (CONSTANTINIDES, 2004). 
O grau de envolvimento com a compra é um fator-chave para moldar o tipo de processo de decisão que os consumidores estão seguindo. Blackwell et al (2005, p. 95) definem o envolvimento como

o nível de importância pessoal percebida e/ou interesse despertado por um estímulo em uma situação específica, em que o consumidor age deliberadamente para minimizar o risco e maximizar os benefícios obtidos com a compra e o uso.

Nas compras de alto envolvimento, Minor e Mowen (2003) ressaltam a predominância de estratégias compensatórias, em que as atitudes são determinantes na constituição das intenções e do comportamento, dentro de um modelo de aprendizagem padrão.

Nas compras com hierarquia de baixo envolvimento, como resultado do processo menos intenso de coleta de informações para a definição das alternativas de compra e menor processamento comparativo das opções, há predomínio de estratégias não-compensatórias, com o surgimento das atitudes acontecendo majoritariamente após o comportamento (MINOR, MOWEN, 2003).

O alto ou baixo envolvimento também é uma questão diretamente relacionada à experiência do comprador; produtos comprados pela primeira vez, em geral, requerem maior envolvimento do que aqueles comprados com frequência (BOYD et al, 2002).

\subsubsection{Compra}

O estágio seguinte do processo de decisão do consumidor é a compra. Depois da decisão pela compra do produto, os consumidores passam por outras duas fases de escolha. A primeira consiste na do meio para executar a compra em si (catálogos, venda online, loja física, etc.), e a segunda envolve a escolha do produto específico dentro da loja, sob influência do vendedor, materiais de ponto de venda, etc. (BLACKWELL et al, 2005).

Como já visto anteriormente, o foco deste estudo concentra-se exatamente nos aspectos relacionados à primeira fase do processo de compra, quando o consumidor está fazendo a avaliação do meio mais adequado para adquirir seu produto.

Embora vários autores sigam um caminho semelhante ao proposto por Blackwell et al (2005), Kotler e Keller (apud OLIVEIRA, 2007) apresentam uma visão alternativa, em que a decisão 
da marca selecionada acontece já na avaliação das alternativas, restando ao estágio de compra em si a decisão sobre o revendedor, a quantidade, ocasião, forma de pagamento, etc.

Diversas circunstâncias e fatores parecem atuar neste processo de decisão de meio e marcas, a destacar o nível de planejamento da efetivação da compra em si.

Em situações de compra em que não há influências circunstanciais de impedimento, adiamento ou mudança de planos (como falta de produto, ágio, etc.), o processo de decisão pode ser classificado em três vertentes de acordo com o nível de planejamento do consumidor em relação à compra, como pode ser visto na tabela que segue.

Tabela 2 - Tipos de processo de decisão de compra, quanto ao planejamento

\begin{tabular}{lccc}
\hline Tipo de Compra & Totalmente Planejada & Parcialmente Planejada & Não Planejada \\
\hline Escolha do Produto & Antecipada & Antecipada & No local da compra \\
Escolha da Marca & Antecipada & No local da compra & No local da compra \\
Envolvimento & Alto & Alto / Baixo & Baixo \\
\hline
\end{tabular}

FONTE: Elaborado pelo autor com base em Blackwell et al (2005).

Quanto maior o nível de planejamento envolvido no processo de decisão de compra, maior tende a ser a antecipação do consumidor em relação às decisões de compra, tanto no primeiro estágio (comprar o produto ou não, em qual meio, etc.) quanto em relação ao segundo estágio (produto, marca, pagamento, etc.).

\subsubsection{Escolha do tipo de varejista}

A maioria dos acadêmicos concorda que fatores demográficos, sociais, econômicos, culturais, psicológicos, e diversos outros que estão além da capacidade de influência do profissional de marketing, exercem uma influência primordial no comportamento de compra e especificamente na decisão do meio de compra (BOYD et al, 2002; JOBBER, 2001; SOLOMON, STUART, 2003).

No processo de decisão do consumidor, considerar qual tipo de varejo (Internet, mala direta, catálogo, loja física, etc.) geralmente precede a escolha de qual tipo de loja (grande varejista, 
hipermercado, loja de departamentos, loja especializada, etc.) e qual varejista específico será escolhido (BLACKWELL et al, 2005).

Estas escolhas estão intimamente relacionadas e o processo de decisão frequentemente envolve aspectos que concernem ambas esferas, sofrendo influências de preferências pessoais, critérios de avaliação do consumidor, além de outros fatores situacionais específicos da compra do produto em questão (MINOR, MOWEN, 2003).

A figura 4 exibe de forma esquemática como os consumidores normalmente decidem o tipo de varejista mais adequado para sua compra:

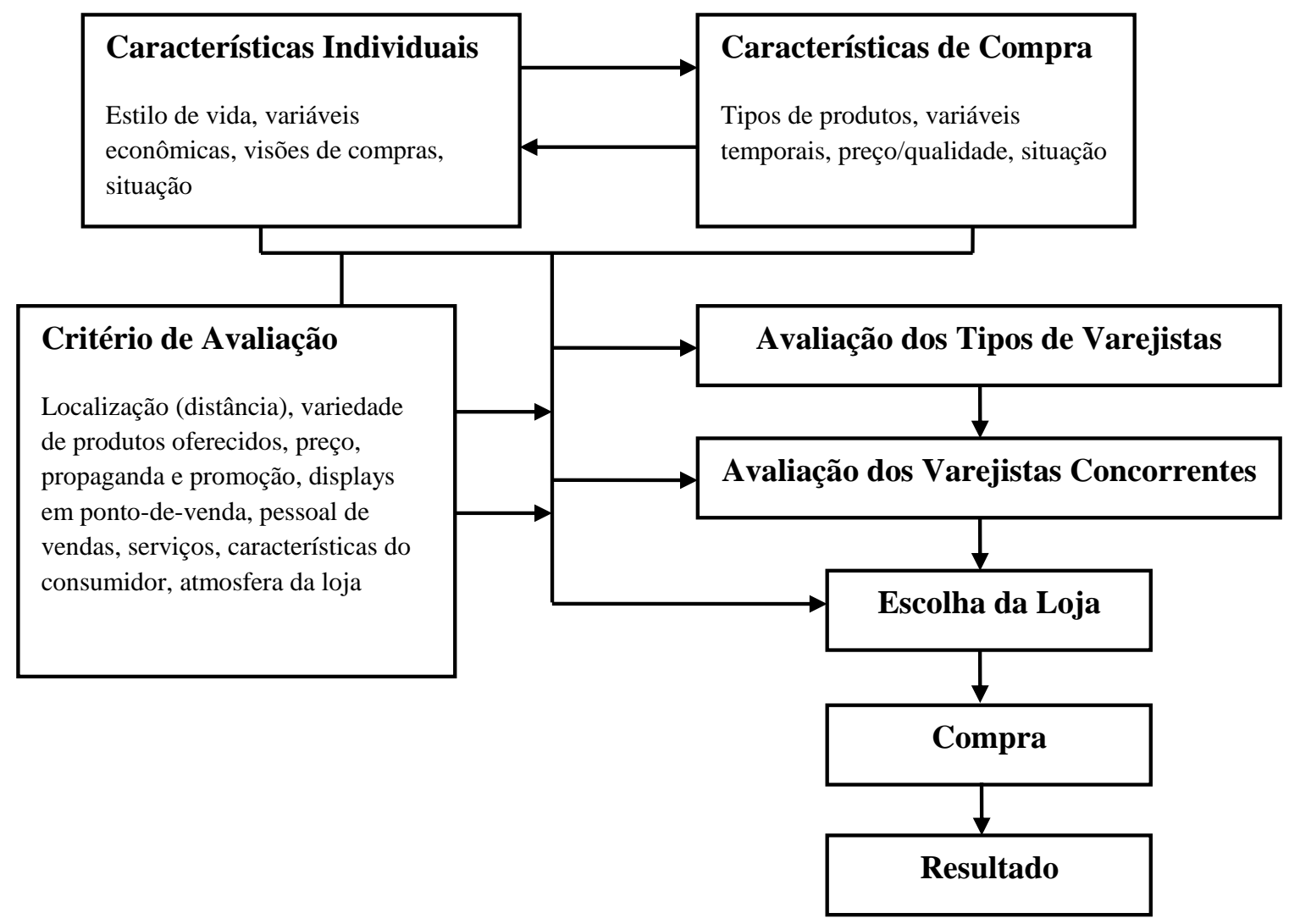

Figura 4 - Processo de decisão do varejista

FONTE: Adaptado de Blackwell et al (2005).

Como pode ser observado, há uma série de fatores que influenciam o sucesso ou fracasso de um varejista. Estas determinantes variam de acordo com o tipo e categoria do produto em questão, mas em geral compõe um grupo de variáveis bem definidas: localização, variedade de produtos oferecidos, preço, propaganda e promoção, características do cliente, atmosfera da loja, serviços pós-compra, e satisfação (BLACKWELL et al, 2005). 
Blackwell et al (2005, p. 88-90) também indicam três grupos de variáveis que exercem influência no processo de tomada de decisão do consumidor:

a) Diferenças Individuais: demografia, psicografia, valores e personalidade; recursos do consumidor, como tempo, dinheiro e atenção; motivação; conhecimento e atitudes.

b) Influências ambientais: cultura, classe social, família, influência pessoal e situação.

c) Processos psicológicos: processamento de informação, aprendizagem e mudanças de comportamento e atitude.

No caso específico da Internet, a tecnologia do varejo eletrônico determina o que pode ser oferecido aos clientes, porém as mesmas dinâmicas de avaliação e as mesmas variáveis de influência usadas nas lojas físicas podem ser aplicadas ao meio digital.

O grande desafio das lojas virtuais é entender como cada um destes elementos impacta a realização de vendas, e então usar as ferramentas que compõem o marketing mix para tentar tornar sua oferta a mais adequada para a efetivação das vendas (KOTLER, 2003).

\subsection{Motivadores e inibidores de compra online}

Dentro do processo de compra, há diversos elementos que podem desempenhar um papel moderador ou até mesmo decisor do meio de efetuação da transação de compra, e entender algumas de suas dinâmicas e a influência que eles exercem é justamente o ponto central deste estudo.

Retomando o conceito que inicia todo o processo de compra, Solomon (1998) indica que a motivação ocorre quando uma necessidade é despertada e o consumidor precisa satisfazê-la.

Particularmente, na Internet há diversas questões e motivações que permeiam a compra. Para Wolfinbarger e Gilly (2001), consumidores se comportam de forma desigual na realização de compras online dependendo se suas motivações são primariamente experienciais ou orientadas ao cumprimento de objetivos. 
Não obstante, de acordo com Wolfinbarger e Gilly (2001), a opção pela compra online estaria muito mais relacionada às motivações orientadas a objetivos. Compradores online tenderiam a querer diminuir o tempo gasto no processo de busca de opções diminuindo o escopo de busca, e a facilidade proporcionada pela rede na busca seria exatamente um viabilizador da obtenção deste benefício.

Analogamente, Hoffman et al (2002) apontam que usuários mais avançados de Internet tendem a apresentar um locus interno de controle mais forte, e personalidade voltada ao cumprimento de objetivos.

Esta característica, em um processo de retro-alimentação, estaria diretamente relacionada à disponibilidade de ferramentas proporcionadas pela Internet para localizar o produto desejado com o máximo de informações em um tempo relativamente curto, o que reforçaria este comportamento especificamente na compra online.

Lynch e Ariely (2000) concordam com a visão de que as características e ferramentas proporcionadas pela Internet facilitam um comportamento utilitário de compra pela comparação objetiva de atributos e preços dos bens e serviços procurados.

Com isto, o comportamento de compra online tende a ser menos hedônico do que a compra realizada em lojas fisicamente estabelecidas (WOLFINBARGER, GILLY, 2001).

Contrapondo esta visão, Childers et al (2001) revelam que, embora a valorização por parte dos usuários dos aspectos instrumentais proporcionados pela Internet (o autor destaca a economia de tempo e maior eficiência no processo de compra, entre outros) seja um bom preditor da atitude do usuário em relação à compra online, os aspectos hedônicos desempenham um papel de igual importância.

Os próprios Hoffman e Novak (1996), em outro trabalho, apontam que a compra pela Internet pode induzir a um estágio psicológico de tal envolvimento por parte do usuário que este acaba perdendo a noção de tempo e se vê imerso em uma situação de prazer e diversão. 
Isto aconteceria em situações de navegação online nas quais os indivíduos têm sua atenção voltadas à busca de informações, havendo certa perda de consciência em relação ao mundo real (HOFFMAN, NOVAK, 1996).

Outro significativo aspecto é o maior controle sobre o tempo gasto e o desenvolvimento de cada etapa de compra. Wolfinbarger e Gilly (2001) ressaltam que os compradores gozam de maior controle e liberdade no ambiente online, como resultado da menor pressão de compra existente antes que eles se sintam absolutamente preparados para efetuá-la.

Seria justamente a própria natureza "auto-serviço" da compra online que permite um alto nível de controle sobre o ambiente e o processo de compra (FRANCIS, WHITE, 2004; MEUTER et al, 2000).

Seguindo o mesmo princípio, além da ausência de pressão do vendedor, a diminuição da coerção social de outros compradores e agentes externos para a finalização da compra também aumenta o controle do usuário sobre o processo de compra, o que pode ser citado como elemento que favorece a opção por este ambiente online.

Elementos associados à conveniência de compra também são comumente citados, como acessibilidade, comparação de preços e facilidade transacional (BAKOS, 1997; CHILDERS et al, 2001; WOLFINBARGER, GILLY, 2001).

Na mesma linha, apesar de alguns aspectos negativos - como a dificuldade de avaliar a qualidade do produto, inseguranças em relação ao processo de pagamento e gratificação adiada - compradores online normalmente indicam que comprar pela Internet é mais fácil do que em uma loja física, principalmente pela facilidade de acesso, comparação entre opções e maior sortimento de produtos (CHILDERS et al, 2001; WOLFINBARGER, GILLY, 2001).

Parece haver um certo consenso entre os autores de que a grande disponibilidade de informações é uma das razões mais importantes para que consumidores optem por comprar online. A variedade e abundância de informação sobre os produtos e serviços avaliados permite que os consumidores embasem melhor seu processo de decisão e, em última instância, diminuam a possibilidade de dissonância cognitiva pós-compra, como visto no segmento em que foi analisada a etapa de busca de informações. 
Outro aspecto a ser considerado é a questão da interação social como parte do processo de realização da compra. Na literatura sobre o tema parece não haver um consenso se a falta de socialização pela compra online constitui um fator de motivação ou inibição.

Nicholson et al (2002) afirmam que a falta de socialização pode ser um aspecto que favorece a escolha da compra online por parte dos consumidores. Neste caso, a opção pela compra online decorre da antecipação da expectativa dos consumidores de que na compra realizada na loja física haverá ineficiências no atendimento de vendas, ou interações verbais indesejadas que podem diminuir a eficiência no processo de compra.

Entretanto, outros autores revelam que a falta de socialização pode ser igualmente apontada como um inibidor da compra online. Zeithaml et al (2002), por exemplo, indicam que os consumidores podem desejar conversar com um vendedor quando a compra em questão é de um produto mais complexo, ou em uma compra em que há alto envolvimento do comprador com o produto em questão.

E mesmo Nicholson et al (2002) concordam que os consumidores podem querer discutir com sua família e amigos quando o produto avaliado tem parte de seu valor derivado da interação social.

Como reflexo desta situação de falta de clareza em relação à questão, é facilmente observável um movimento entre as principais redes varejistas no sentido de disponibilizar um atendimento online por meio de mensagens instantâneas de forma on-demand; ou seja, uma equipe de atendimento fica disponível para realizar um bate papo online com o potencial comprador, mas apenas entra em ação após ser solicitada pelo usuário.

De forma geral, os fatores que previnem os consumidores de comprarem online referem-se particularmente à percepção de aumento do risco. Já foi demonstrado na literatura clássica de administração que a percepção de nível de riscos sociais, de performance, físicos, financeiros e psicológicos variam de acordo com o canal de compra (COX, RICH, 1964).

No ambiente online, a distância física e temporal entre consumidores e varejistas cria uma incerteza adicional devido à impossibilidade de se avaliar plenamente as características do 
produto e a identidade do varejista durante a transação, e pela maior facilidade em se praticar fraudes e roubos (REICHHELD, SCHEFTER, 2000).

Em ambientes online, os consumidores também têm menos elementos tangíveis e passíveis de verificação para atestar a capacidade e idoneidade do varejista de honrar seus compromissos, o que leva a uma maior percepção de risco. Embora a transação como um todo pareça sempre mais rápida e conveniente, os processos de transação ocorridos internamente para a efetuação da operação são normalmente mais complexos do que os que ocorrem nas lojas físicas (ARNOLD et al, 2007).

Por consequência da falta deste lastro mais forte de segurança, é fácil concluir que varejistas de maior porte, com uma marca forte e bem estabelecida mesmo no mundo offline, tem maiores chances de diminuir estas incertezas associadas ao processo de compra online, e desta forma, captar mais vendas também no meio digital.

Dentro deste contexto, a confiança na empresa é frequentemente vista como um facilitador da compra online, uma vez que reduz a percepção de risco (EINWILLER, 2003).

Embora mecanismos tenham sido criados para estimular que usuários troquem recomendações e informações sobre o desempenho de um website para atestar a qualidade do serviço e cumprimento das obrigações assumidas pelo varejista avaliado, a questão da segurança principalmente permanece como uma das maiores preocupações dos usuários.

Segurança e privacidade são preocupações frequentemente mencionadas como inibidores da compra online (WOLFINBARGER, GILLY, 2001; ZEITHAML et al, 2002).

Zeithaml et al (2000) mencionam que outros agentes inibidores podem aparecer com tanta intensidade, ou ainda maior, na compra de bens/produtos físicos. A impossibilidade de ver, sentir ou experimentar o produto antes da compra pode inibir alguns potenciais consumidores de comprar online.

A impossibilidade da gratificação instantânea - com os clientes tendo que esperar até que o produto seja entregue - também é fator de desestímulo à compra por impulso (FRANCIS, WHITE, 2004; WOLFINBARGER, GILLY, 2004). 
Finalmente, Seiders et al (2000) complementam que a expectativa de gastos adicionais de remessa do produto caso o consumidor queira trocar ou devolver o produto adquirido também é outro fator que potencialmente pode inibir a compra online.

Uma área de discussão em que parece não haver um consenso é o efeito do preço na motivação da compra online.

As pesquisas desenvolvidas na área têm procurado identificar se a sensibilidade por preços é maior em compradores online. A hipótese é que a Internet representou um importante avanço na diminuição dos custos de busca por informação, tornando a informação e a comparação de preços de diferentes produtos disponíveis para os consumidores e, com isto, tornando os mercados online mais competitivos do que o varejo tradicional (BAKOS, 1997).

Lynch e Ariely (2000) pontuam que websites que facilitam a comparação de preços aumentam a sensibilidade de preço dos consumidores em busca de produtos comuns, e diminuem a demanda por itens únicos.

Em um extenso trabalho de levantamento de dados no campo, Brynjolfsson e Smith (2000) encontraram preços online aproximadamente de $9 \%$ a $16 \%$ mais baixos do que os similares em lojas varejistas fisicamente estabelecidas.

Mesmo considerando apenas o ambiente online, a variação de preços entre lojas, vendendo um mesmo item, ocorre como resultado de uma grande quantidade de fatores. A variação de preços para produtos iguais pode ser explicada, por exemplo, por diferentes níveis de qualidade de serviço, prazo de entrega, reputação da loja, entre outros (LYNCH, ARIELY, 2000).

A própria decisão de compra de consumidores online não é tomada exclusivamente com base no preço, mas também em uma série de outros dados como quantidade de informações disponíveis sobre o produto, qualidade do serviço, qualidade do produto, entre diversos itens. 
Lynch e Ariely (2000) demonstraram que projetar um website que facilita a comparação de qualidade entre produtos diminui a sensibilidade a preço dos usuários para itens únicos (especiais).

Outra visão que segue esta mesma linha é a de que compradores online podem ser menos sensíveis a preço por atribuírem maior valor relativo ao tempo. Nesta linha, eles estariam dispostos a aceitar preços maiores comprando online do que gastar tempo pessoal buscando opções mais baratas em lojas físicas (RATCHFORD et al, 2003).

Em um esforço para tentar identificar as razões deste fenômeno, Ratchford et al (2003) argumentam que a grande dispersão de preços na Internet é resultado da recenticidade e imaturidade deste canal de vendas. Avaliando preços online em dois diferentes períodos de coleta (com 1 ano de intervalo entre elas), identificaram que houve decréscimo substancial de preços no período. Assumindo que outros fatores de impacto na formação do preço tenham se mantido constantes, o trabalho dos pesquisadores concluiu que a diminuição do preço cobrado pelos mesmos itens teve relação com o aumento da maturidade decorrente do maior tempo de operação das lojas na venda online.

Todavia, de uma forma geral, os estudos nesta área não parecem ser conclusivos se os preços praticados online são substancialmente diferentes dos preços praticados nas lojas físicas. Igualmente não foi determinada relação entre a sensibilidade a preço dos consumidores e a tendência a comprar na Internet (DONTHU, GARCIA, 1999).

Consumidores mais sensíveis a preço podem se sentir motivados a usar a Internet para procurar pelos menores preços aproveitando a facilidade e baixos custos de busca proporcionados pelo meio.

E mesmo consumidores menos sensíveis a preço podem se valer da facilidade de comparação proporcionada pela Web para comparar características, informações e outros dados nãorelativos a preço dos produtos como parte do processo de coleta de dados para a decisão de compra.

Outra área em que parece não haver consenso entre os autores é na relação de características demográficas e sociais na intenção do uso da Internet para compras. Estudos conduzidos por 
Bhatnagar et al (2000) sobre a influência do gênero na preferência pela compra online não apontaram influência deste fator na disposição em comprar online, havendo diferença de atitude apenas em relação a alguns produtos específicos.

Por outro lado, estudos mais recentes conduzidos com consumidores online americanos apontaram que homens teriam maior disposição à compra online do que pessoas do sexo feminino (BECKER, 2007; TEO, 2001).

As mesmas contradições podem ser verificadas no tocante à influência do fator idade na compra online. Contrário ao senso comum de que pessoas mais jovens estariam mais abertas à aceitação de tecnologia e experimentação da compra online (ANDERSON, 2006), alguns autores indicaram que o avançar da idade do usuário aumenta a intenção de uso da Internet para a realização de compras (BELLMAN et al, 1999; BHATAGNAR et al, 2000; TEO, 2001). Contudo, os resultados não foram confirmados em estudo mais recente realizado por Becker (2007), que não apontou associação significativa entre os dois fatores.

Entre os estudos avaliados, a única questão que parece exercer efeito relevante é a experiência - aqui entendida como o tempo de uso total da Internet - que apresentou impacto significativo na aceitação e conforto do uso comércio eletrônico. Em estudos realizados com usuários americanos e europeus, ficou constatada a relação positiva entre experiência de uso da Internet e propensão a usá-la para a compra de bens e serviços (BECKER, 2007; CORBITT et al, 2003; KIM et al, 2000).

Em suma, como principais conclusões da revisão da literatura sobre comportamento de compra online, os consumidores que optam pela Internet para comprar produtos e serviços normalmente são motivados por fatores ligados à conveniência de compra, maior sortimento de produtos, nível de informação sobre os produtos e controle sobre o processo de compra.

Não parece haver conclusões em relação às motivações de compra online e nível de preços praticados neste ambiente, se o nível de socialização necessário é um motivador ou inibidor da compra pela Internet, assim como se características demográficas exercem relação significativa no processo. 
Como fatores desmotivadores da compra online podem ser destacados: a percepção de risco envolvida na compra, a impossibilidade de se avaliar fisicamente o produto antes da compra, o tempo adicional de entrega, e a dificuldade de devolução ou troca de produtos com problema. 


\section{MÉTODO DE PESQUISA}

Como forma de identificar os principais aspectos motivadores e inibidores de compra online aplicados ao contexto do varejo no Brasil, bem como avaliar a relação entre outros fatores adjacentes, além de determinar as características demográficas entre os usuários de Internet, foi conduzida uma pesquisa de campo.

Para tanto, uma vez já definidos os objetivos de pesquisa, buscou-se encontrar a abordagem metodológica mais adequada.

Diversos autores definem a pesquisa como um processo que utiliza procedimentos científicos com o objetivo de identificar respostas para problemas (GIL, 2000; LAKATOS, MARCONI, 2000; MARTINS, 2002; SELLTIZ et al, 1959).

Moreira (2002, p. 11) define a pesquisa científica como “[...] uma busca de informações feita de forma sistemática, organizada, racional e obediente a certas regras.”

A pesquisa é conduzida no espírito da investigação que se baseia em fatos, experiência e dados, conceitos e construtos, hipóteses e conjecturas, princípios e leis (AMARATUNGA et $a l, 2002)$.

Dentro da mesma visão, Lakatos e Marconi (2000) apontam a importância do emprego de métodos científicos como forma de assegurar a segurança, validade e qualificação na obtenção de conclusões como resultado da atividade científica.

Conforme o enfoque epistemológico, há diferentes tipos de pesquisa. Não há um único referencial. A literatura sobre metodologia científica apresenta um grande número de tipos de classificação de estudos ou pesquisas.

Martins (2002) sintetiza as abordagens de pesquisa em estudos empírico-analíticos, fenomenológico-hermenêuticos, ou crítico-dialéticos. 
Já Demo (1981), por exemplo, declara que nas ciências sociais podem ser reconhecidos estudos:

- Teóricos: dedicados à formulação de quadros de referência e estudos de teorias;

- Metodológicos: dedicados a indagar por instrumentos, por caminhos, por modos de se fazer ciência, ou produzir técnicas de tratamento da realidade, ou discutir abordagens teórico-práticas;

- $\quad$ Empíricos: dedicados à codificação da face mensurável da realidade social;

- Práticos: voltados para intervir na realidade social.

Malhotra (2001) classifica como exploratórias as pesquisas com o objetivo de levantar dados relevantes que possam ser usados na definição de uma abordagem de pesquisa mais aprofundada de um problema; ou como conclusivas aquelas que têm como objetivo determinar, avaliar e mensurar o conhecimento sobre determinado assunto, avançando o estado da arte do conhecimento no tocante à sua temática.

Dentro desta abordagem, o que difere essencialmente o primeiro do segundo tipo é o grau em que o problema de pesquisa está cristalizado. As pesquisas exploratórias visam evidenciar variáveis importantes para o estudo do tema, levantar prioridades para futuras pesquisas e até mesmo gerar hipóteses para serem testadas em futuras pesquisas conclusivas (MATTAR, apud GALHANONE, 2008).

As pesquisas também podem ser classificadas como qualitativas ou quantitativas, pela natureza das variáveis pesquisadas. Malhotra (2001) define a pesquisa quantitativa como a que permite analisar um grande número de casos estruturados, fazendo uso de técnicas estatísticas para analisar os dados e generalizações dos resultados para a população-alvo (no caso da pesquisa realizada com amostra probabilística).

Moreira (2002) indica que, entre outras coisas, pesquisas quantitativas podem ser projetadas para medir atitudes, crenças ou comportamentos das pessoas. 
Entretanto, por outro lado, Denzin e Lincoln (2000) definem a pesquisa qualitativa como um conjunto de práticas materiais e interpretativas de pesquisa que permitem uma abordagem interpretativa e natural de fenômenos sociais.

Da mesma forma, Shet et al (2001) qualificam a pesquisa como qualitativa quando mensura em termos de descrições e categorias gerais (não-numéricas).

Existe uma certa controvérsia nos meios acadêmicos e grande discussão acerca da validade científica das pesquisas qualitativas. Seu caráter mais interpretativo e baseado na habilidade da figura do pesquisador em identificar padrões de relações e comportamento despertam certo descrédito entre alguns pesquisadores.

Gilgun (2006) discute se é possível conduzir um projeto de pesquisa qualitativa útil, efetivo e válido cientificamente e o papel das descobertas de pesquisa, referências teóricas e metodologias dentro de um projeto de pesquisa com este perfil.

Por outro lado, Silverman (1998) aponta que, embora tenha sido historicamente difícil para pesquisadores qualitativos discutir o caráter objetivo do conhecimento gerado por seus trabalhos, a geração de dados históricos de acompanhamento em projetos regulares permite a formação de uma base de comparação que proporciona bastante rigor na avaliação da evolução da observação de um fenômeno.

Neste estudo, a abordagem de pesquisa será de caráter empírico-analítica, utilizando as técnicas de coleta, tratamento e análise de dados marcadamente quantitativos.

O desenvolvimento do estudo realizou-se em duas etapas. A primeira, uma vertente de cunho mais exploratório, foi o levantamento dos referenciais teóricos do estado da arte da produção acadêmica que foi realizada acerca do tema na literatura. $\mathrm{O}$ objetivo foi constituir uma base sólida do conhecimento já existente sobre o tema para que a pesquisa de campo pudesse efetivamente manter seu caráter inédito e levantar dados e informações que pudessem complementar o conhecimento existente.

Para cumprir tal objetivo, foram consultados livros, periódicos, jornais acadêmicos, dissertações, teses, revistas e sites especializados no tema. Do mesmo modo foram 
consultados profissionais e o acervo de pesquisa disponível por associações e entidades ligadas à mensuração da atividade de Internet no país.

A segunda etapa da pesquisa foi a pesquisa de campo de caráter quantitativo, com o objetivo de aprofundar o conhecimento existente acerca do comportamento de compra na Internet.

\subsection{Coleta e tratamento dos dados}

\subsubsection{Universo e Amostra}

Como a realização de uma pesquisa de caráter censitário na Internet seria inviável pelos custos envolvidos, pelo grande universo de pessoas a serem entrevistadas, e pela enorme complexidade de execução, optou-se pelo uso de uma amostra colhida entre usuários de Internet no país, que tenham ou não já realizado compras pela rede.

Diante da dificuldade de determinar uma amostra probabilística desta população, pelo caráter irregular de navegação dos usuários, e pela impossibilidade de se conseguir proporcionar chance igual de participação na amostra, optou-se por utilizar uma amostra não-probabilística, usando uma técnica de amostragem intencional.

Malhotra (2001) define amostra não-probabilística como aquela em que nem todos os integrantes da população pesquisada têm conhecida e igual probabilidade de serem selecionados para a pesquisa.

Na mesma linha, Baker (2002) aponta que amostra probabilística é aquela em que todos os membros da população definida tem uma chance conhecida e diferente de zero de ser incluída na amostra, o que não será o caso deste estudo.

$\mathrm{Na}$ amostragem intencional, de acordo com um determinado critério, é escolhido intencionalmente um grupo de elementos que irão compor a amostra (MARTINS, 2002). No caso deste estudo, serão coletadas respostas entre usuários de Internet que utilizam serviços de 
um buscador na Internet. A escolha pela estratificação com base no uso de um serviço (no caso, o de busca) proporciona algumas vantagens:

- $\quad$ A grande cobertura do serviço entre a população usuária de Internet no Brasil (81\% dos usuários com acesso ao meio, de acordo com o relatório de julho de 2008 do instituto Nielsen Net Ratings);

- $\quad$ A possibilidade de exibição aleatória dos enunciados de convite à participação na pesquisa entre os usuários do serviço.

Com isto, embora a amostra utilizada caracterize-se tecnicamente como intencional, ela permitirá que o estudo seja conduzido dentro dos parâmetros e limitações de custos e acesso, e não invalidará o esforço de cumprimento dos objetivos propostos para a pesquisa.

Para o dimensionamento do tamanho da amostra, optou-se por calcular o número de casos tomando por base as fórmulas utilizadas para amostras probabilísticas, admitindo tratar-se de uma população infinita. Ainda que a amostra a ser usada não seja efetivamente probabilística, o uso da fórmula foi adotado apenas como parâmetro de dimensionamento.

A fórmula para cálculo do tamanho da amostra adotada então é a recomendada para variáveis intervalares e com populações consideradas infinitas (MARTINS, 2002, p. 44):

$$
n=\left(\frac{Z x \sigma}{d}\right)^{2}
$$

Onde:

$n=$ Tamanho da amostra

$Z=$ Abcissa da curva normal padrão, fixado um nível de confiança

$\sigma=$ Desvio-padrão da população

$d=$ Erro amostral

Adotando-se um nível de confiabilidade de 2 sigma $(\sigma)$ (95,5\%), com margem de erro máxima de $6,5 \%$, e assumindo-se um desvio padrão de 0,5 (que admite o maior tamanho de 
amostra, admitindo-se constantes os demais elementos), a indicação do tamanho da amostra deve ser:

$$
n=\left(\frac{1,96 \times 0,5}{0,065}\right)^{2}=227
$$

Para a análise dos dados e particularmente dos elementos motivadores e inibidores do comportamento de compra online serão considerados tanto os respondentes que já realizaram compras online quanto aqueles que nunca efetuaram uma compra pela Internet.

\subsubsection{Instrumento de coleta de dados}

O instrumento de coleta de dados escolhido foi um questionário estruturado do tipo "survey", com perguntas fechadas e com ordem pré-estabelecida. $\mathrm{O}$ mesmo questionário foi exibido para todos os participantes do estudo.

Foram levantados dados demográficos e características do uso da Internet feitos pelo entrevistado por meio de perguntas diretas, além de propostas questões de múltipla escolha, construtos e assertivas expressando juízos de valor sobre determinados conceitos relacionados ao tema de pesquisa.

A escolha por este instrumento deu-se devido à facilidade de comparação entre as respostas coletadas, proporcionada pela padronização das condições de participação, e da objetividade do método no levantamento de dados que permitam a mensuração e o dimensionamento dos fenômenos analisados.

Os participantes foram convidados a responder à pesquisa clicando em um anúncio-convite exibido usando a rede de links patrocinados do Yahoo Brasil, que constitui - junto com a rede de links patrocinados do Google - as duas únicas redes de links patrocinados existentes no país atualmente, e portanto, engloba parcela significativa dos usuários de busca do país, independente do portal utilizado. 
Nos links patrocinados, as empresas que desejam anunciar seus produtos ou serviços submetem as informações de seus anúncios indicando a lista de palavras-chave que quando buscadas pelos usuários são relacionadas aos produtos anunciados.

Quando um consumidor busca por uma palavra ou uma combinação de palavras-chave na ferramenta de busca de um portal de Internet, os links patrocinados do anunciante são exibidos ao lado dos resultados orgânicos (naturais) que são trazidos pelo site.

Para que a pesquisa não estivesse associada a um grupo específico de palavras-chave, direcionando, desta forma, o perfil da amostra a um grupo com interesse direto por aqueles termos ou produtos, o anúncio-convite de participação da pesquisa foi fixada na página inicial do site de busca do Yahoo Brasil, antes que o usuário de Internet efetivamente realizasse a busca, e permitindo assim que houvesse chance igual de todos os usuários do site participar da pesquisa, independente do assunto da busca que seria realizada posteriormente.

Ao clicar no anúncio-convite, o respondente era direcionado por meio de um link para o questionário da pesquisa disponível em um formulário eletrônico localizado no endereço $<$ http://www.questionpro.com>.

A coleta dos dados foi realizada no período de 13 de janeiro a 06 de fevereiro de 2009 . Neste período, a chamada com o convite para responder a pesquisa foi exibida para 600 mil pessoas e 5.810 pessoas clicaram no convite e foram direcionadas ao questionário, totalizando uma taxa de clique de 0,97\%. Destas, 609 pessoas começaram a responder o questionário, sendo que 238 pessoas o fizeram de forma completa, sendo considerados os questionários válidos para as análises, resultando em uma taxa de $39,1 \%$ de participantes que responderam o questionário integralmente em relação ao total que começou a fazê-lo; e uma taxa de 4,1\% de conversão entre visualizações e respondentes válidos efetivos.

\subsubsection{Meio de coleta de dados}

Embora os tipos de produtos comprados pela Internet ainda continuem bastante concentrados em poucas categorias - mais de $60 \%$ deles pertence a apenas 5 categorias de produtos - , é possível perceber uma diminuição nesta concentração com o decorrer dos anos. 
A tabela 3 apresenta a participação das 5 principais categorias de produtos nas vendas pela Internet de 2004 a 2006.

Tabela 3 - Participação nas vendas das principais categorias de produtos vendidos na Internet no Brasil

\begin{tabular}{lccc}
\hline \multicolumn{1}{c}{ CATEGORIA } & $\mathbf{2 0 0 4}$ & $\mathbf{2 0 0 5}$ & $\mathbf{2 0 0 6}$ \\
\hline Livros, Jornais e Revistas & $21,5 \%$ & $16,8 \%$ & $18,4 \%$ \\
CDs, DVDs e Vídeos & $27,3 \%$ & $22,2 \%$ & $15,9 \%$ \\
Eletrônicos & $10,1 \%$ & $12,9 \%$ & $14,3 \%$ \\
Informática & $6,1 \%$ & $7,1 \%$ & $8,4 \%$ \\
Saúde e Beleza & $6,7 \%$ & $8,0 \%$ & $7,9 \%$ \\
\hline
\end{tabular}

FONTE: Grupo de pesquisas e-bit (2004, 2005 e 2006).

Com isto, a listagem de produtos comprados pelo meio apontado no questionário levou em consideração um espectro bem mais amplo de produtos, incluindo, por exemplo, diversos serviços que historicamente tiveram seus processos de compra mais associados à venda offline, mas têm crescido em ritmo acelerado no ambiente virtual, além de permitir que os próprios usuários pudessem acrescentar um campo com o produto específico que compraram, caso o mesmo não estivesse listado.

O objetivo desta abertura de escopo é justamente englobar consumidores de produtos que historicamente não estejam diretamente associados à compra online, procurando refletir de forma mais genuína a diversidade das intenções de compra e objetivos encontrada na realidade do uso da Internet.

\subsection{Testes e procedimentos para análise dos dados}

Para que a análise dos dados coletados na pesquisa de campo pudesse ser estruturada de forma a atender aos objetivos propostos no trabalho, foram formuladas hipóteses para cada um dos objetivos específicos desta dissertação, além de indicadas quais as variáveis utilizadas no questionário que serão usadas para tal esforço de aferição, e a técnica estatística usada em cada caso. 
A seguir são apresentados os grupos de informações analisados, bem como as variáveis usadas na coleta dos dados e as técnicas estatísticas empregadas. 
Tabela 4 - Detalhamento dos objetivos específicos

\begin{tabular}{|c|c|c|c|}
\hline Objetivo Específico & Hipótese Alternativa & Variáveis de Análise & Técnica Estatística \\
\hline $\begin{array}{l}\text { OE1. Apontar elementos motivadores e } \\
\text { inibidores da compra online e sua } \\
\text { importância na decisão do meio de } \\
\text { compra. }\end{array}$ & $\begin{array}{l}\text { Ha1. Há elementos motivadores e } \\
\text { inibidores com diferentes importâncias } \\
\text { na compra online. }\end{array}$ & $\begin{array}{l}\text { V1. Avaliação de fatores - Facilidade de acesso, } \\
\text { preço, informação, segurança, conveniência, } \\
\text { socialização e afetividade (Q27) }\end{array}$ & $\begin{array}{l}\text { 1. Análise descritiva } \\
\text { 2. Regressão logística } \\
\text { 3. Razão de odds }\end{array}$ \\
\hline $\begin{array}{l}\text { OE2. Identificar se há relação entre } \\
\text { experiência no uso da Internet e } \\
\text { frequência de compra pelo meio online. }\end{array}$ & $\begin{array}{l}\text { Ha2. Quanto maior a experiência no uso } \\
\text { da Internet, maior a frequência de } \\
\text { compra pelo meio. }\end{array}$ & $\begin{array}{l}\text { V1. Tempo de uso de Internet (Q2); V2. } \\
\text { Quantidade de compras online realizadas em } 12 \\
\text { meses (Q29); V3. Intenção de compra em } 12 \\
\text { meses (Q32) }\end{array}$ & $\begin{array}{l}\text { 1. Análise descritiva } \\
\text { 2. Teste de associação } \\
\text { 3. Teste de aderência }\end{array}$ \\
\hline $\begin{array}{l}\text { OE3. Identificar se há relação entre } \\
\text { satisfação pós-compra nas compras } \\
\text { anteriores realizadas pela Internet e } \\
\text { intenção de compra futura pelo meio. }\end{array}$ & $\begin{array}{l}\text { Ha3. Quanto maior a satisfação com } \\
\text { compras anteriores realizadas pela } \\
\text { Internet, maior a intenção de compra } \\
\text { futura pelo meio. }\end{array}$ & $\begin{array}{l}\text { V1. Satisfação com produtos comprados pela } \\
\text { Internet em relação aos meios físicos (Q33); V2. } \\
\text { Intenção de compra pela Internet em } 12 \text { meses } \\
\text { (Q31) }\end{array}$ & $\begin{array}{l}\text { 1. Análise descritiva } \\
\text { 2. Teste de associação } \\
\text { 3. Teste de aderência }\end{array}$ \\
\hline $\begin{array}{l}\text { OE4. Determinar principais dados } \\
\text { demográficos do comprador online. }\end{array}$ & $\begin{array}{l}\text { Ha4. O comprador online tem um perfil } \\
\text { demográfico diferente do usuário não } \\
\text { comprador online. }\end{array}$ & $\begin{array}{l}\text { V1. Sexo (Q21); V2. Idade (Q22); V3. } \\
\text { Escolaridade (Q23); V4. Estado civil (Q24) }\end{array}$ & 1. Análise descritiva \\
\hline
\end{tabular}




\subsubsection{Pré-teste}

Antes de aplicação final do questionário foi realizado um pré-teste com o objetivo de corrigir problemas na falta de clareza, precisão, entendimento ou adequação das perguntas aos objetivos da pesquisa.

O questionário foi aplicado a um total de 18 pessoas, incluindo alunos de pós-graduação da FEA/USP, além de funcionários de empresas ligadas ao setor de Internet. Com os comentários e feedbacks recebidos no pré-teste, foram feitos ajustes nas perguntas do questionário antes da realização do campo. 


\section{ANÁLISE DOS RESULTADOS}

No processo de tratamento dos dados, alguns procedimentos foram necessários para garantir a consistência e adequação das informações. Com o elevado número de respondentes e o caráter de auto-preenchimento da pesquisa, foram registradas ocorrências de desistências no preenchimento. Não foram registradas ocorrências de dados missing porque todas as questões usadas como variáveis de análise da pesquisa foram colocadas como obrigatórias, não permitindo a continuidade de participação na pesquisa sem que o usuário completasse todos os campos. Os únicos campos passíveis de não-preenchimento foram as informações opcionais.

Todos os casos de desistência de preenchimento foram, então, removidos da amostra considerada para análise, totalizando uma amostra final de 238 casos.

\subsection{Características demográficas da amostra}

O gráfico 5 apresenta a distribuição por gênero da amostra. Embora reflita a tendência geral da Internet de uma maior parcela de homens em relação às mulheres, como é apontado pelo relatório ComScore (2008) de audiência no Brasil, houve uma concentração ainda mais intensa entre o público respondente da pesquisa. 


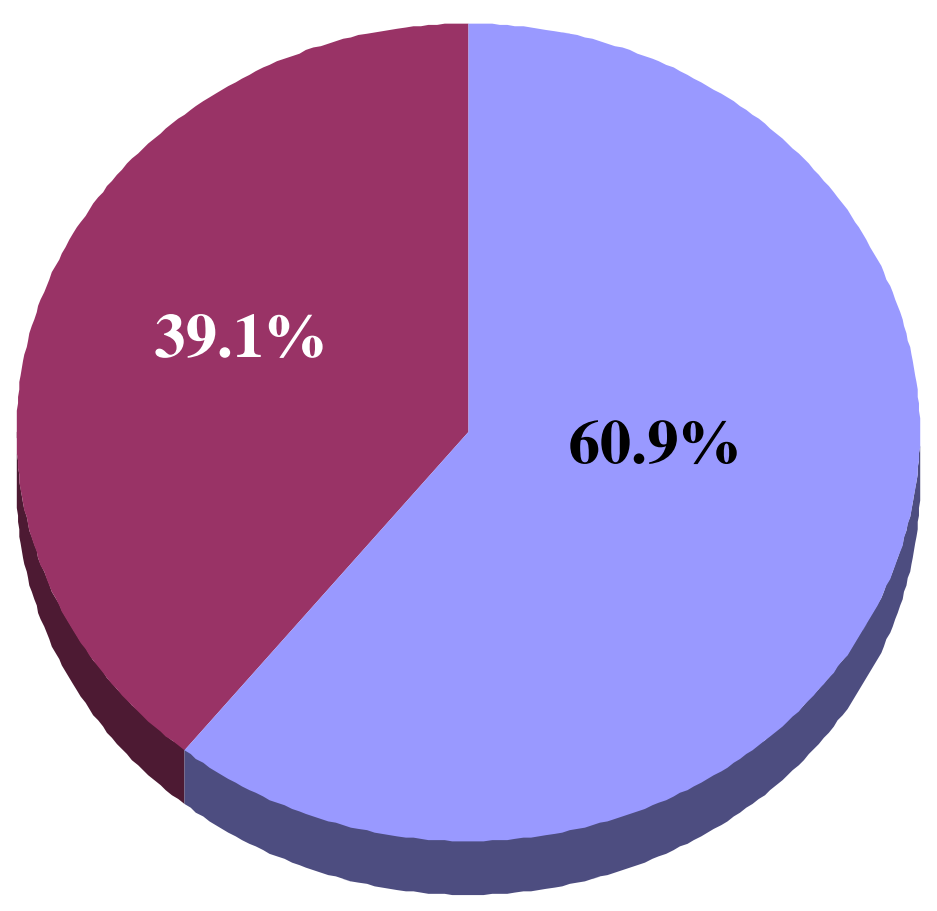

\begin{tabular}{|c|c|c|}
\hline Sexo & n & \% \\
\hline Masculino & 145 & $61 \%$ \\
\hline Feminino & 93 & $39 \%$ \\
\hline
\end{tabular}

Gráfico 5 - Características demográficas da amostra: gênero FONTE: Elaborado pelo autor.

O perfil da distribuição etária dos respondentes também apresenta uma concentração na faixa dos 20 aos 50 anos, que representa mais de $78 \%$ do total de participantes do estudo tanto para o público masculino quanto para o feminino, como pode ser observado nos gráficos 6 e 7 a seguir. 


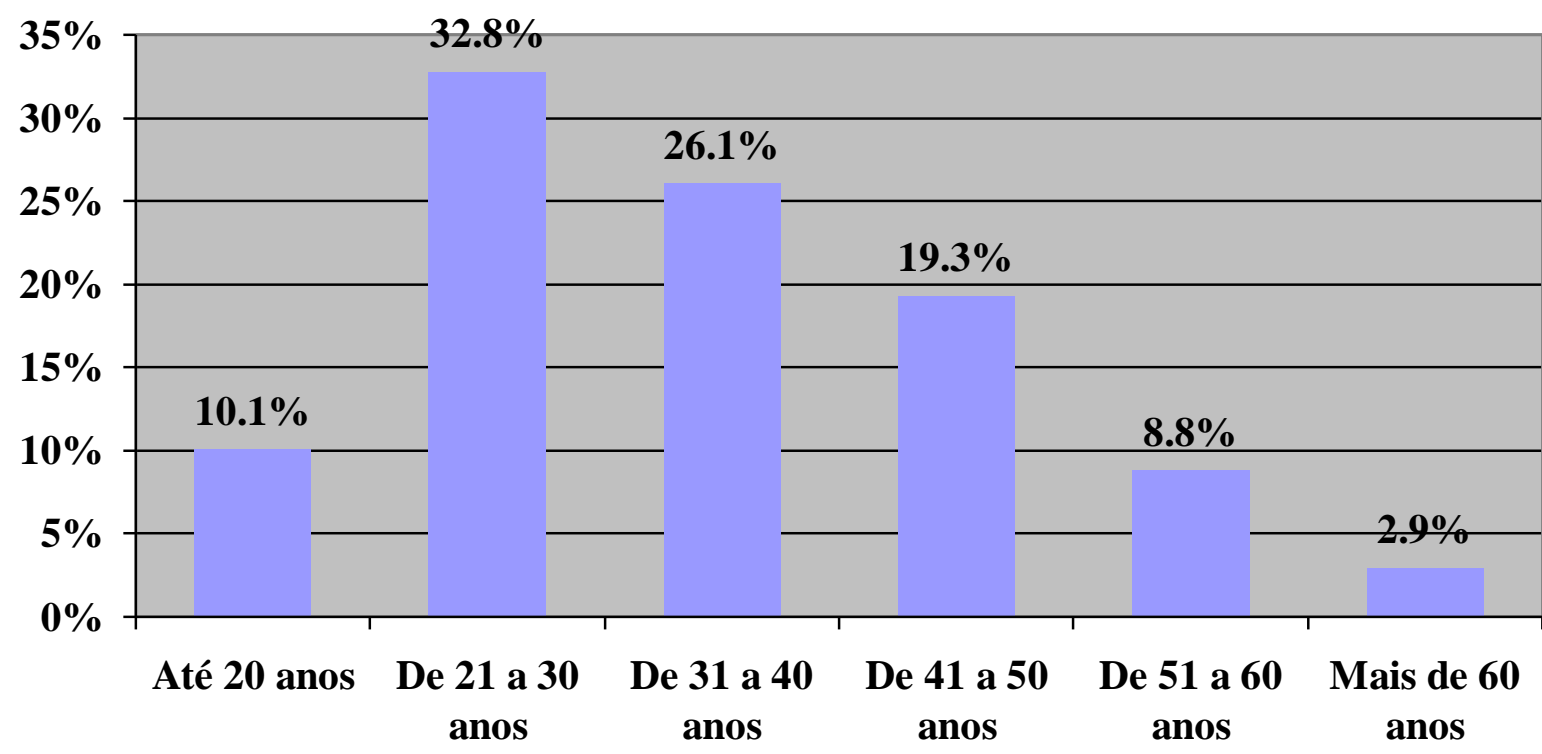

\begin{tabular}{|l|c|c|}
\hline \multicolumn{1}{|c|}{ Faixa Etária } & n & \% \\
\hline Até 20 anos & 24 & $10,1 \%$ \\
\hline De 21 a 30 anos & 78 & $32,8 \%$ \\
\hline De 31 a 40 anos & 62 & $26,1 \%$ \\
\hline De 41 a 50 anos & 46 & $19,3 \%$ \\
\hline De 51 a 60 anos & 21 & $8,8 \%$ \\
\hline Mais de 60 anos & 7 & $2,9 \%$ \\
\hline
\end{tabular}

Gráfico 6 - Características demográficas da amostra: faixa etária FONTE: Elaborado pelo autor. 


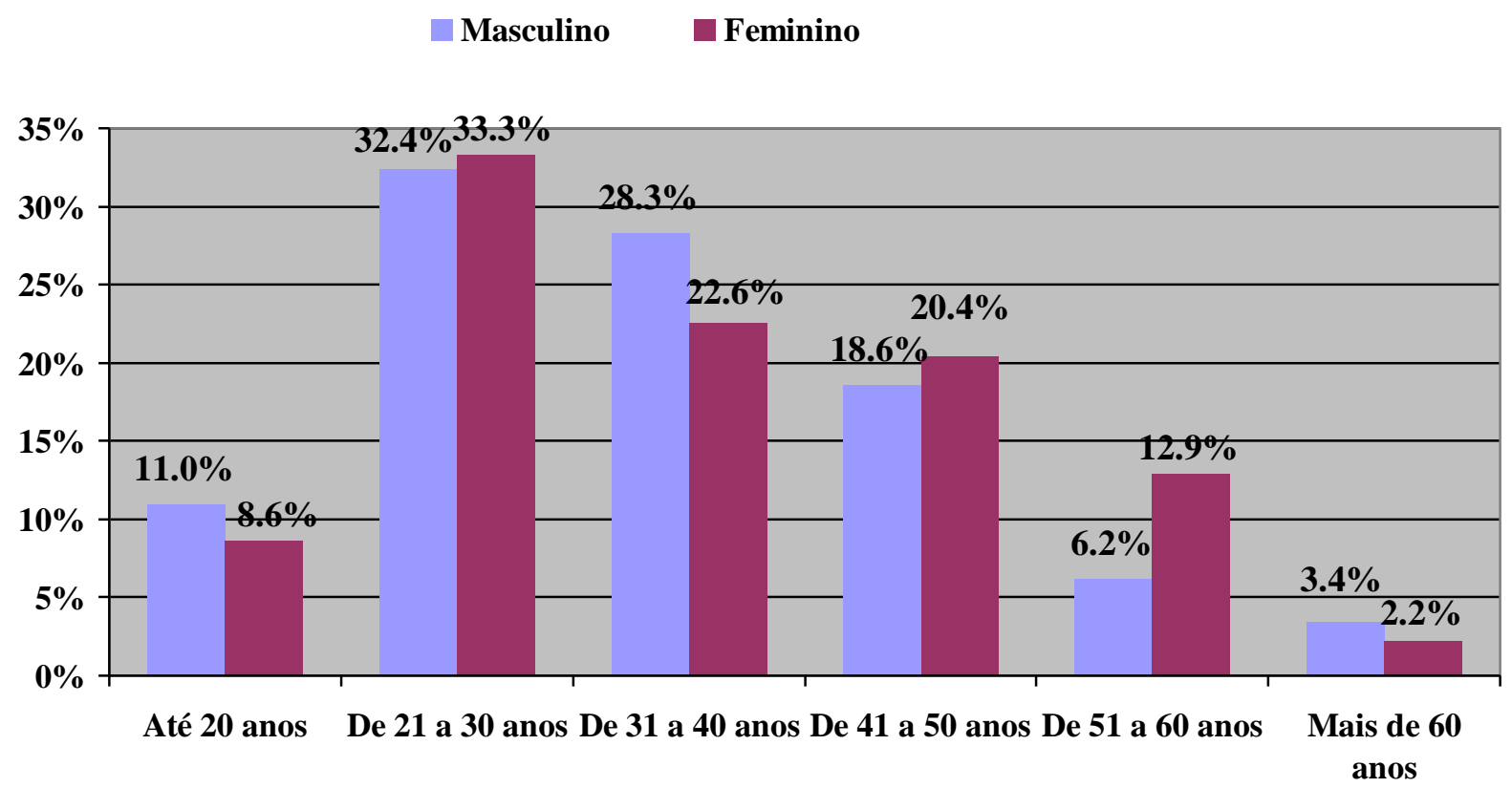

\begin{tabular}{|c|c|c|c|}
\hline Gênero & Faixa Etária & $\mathbf{n}$ & \% \\
\hline \multirow{4}{*}{ Masculino } & Até 20 anos & 16 & $11,0 \%$ \\
\cline { 2 - 4 } & De 21 a 30 anos & 47 & $32,4 \%$ \\
\cline { 2 - 4 } & De 31 a 40 anos & 41 & $28,3 \%$ \\
\cline { 2 - 4 } & De 41 a 50 anos & 27 & $18,6 \%$ \\
\cline { 2 - 4 } & De 51 a 60 anos & 9 & $6,2 \%$ \\
\cline { 2 - 4 } & Mais de 60 anos & 5 & $3,4 \%$ \\
\hline \multirow{5}{*}{ Feminino } & Até 20 anos & 8 & $8,6 \%$ \\
\cline { 2 - 4 } & De 21 a 30 anos & 31 & $33,3 \%$ \\
\cline { 2 - 4 } & De 31 a 40 anos & 21 & $22,6 \%$ \\
\cline { 2 - 4 } & De 41 a 50 anos & 19 & $20,4 \%$ \\
\cline { 2 - 4 } & De 51 a 60 anos & 12 & $2,2 \%$ \\
\cline { 2 - 4 } & Mais de 60 anos & 2 & $12,9 \%$ \\
\hline
\end{tabular}

Gráfico 7 - Características demográficas da amostra: faixa etária - por gênero FONTE: Elaborado pelo autor.

A distribuição por grau de instrução demonstra uma forte presença de respondentes com maior grau de instrução - 57,2\% com nível de educação igual ou acima do superior completo. Os demais gráficos apresentam as características da amostra relativas à ocupação e renda. 


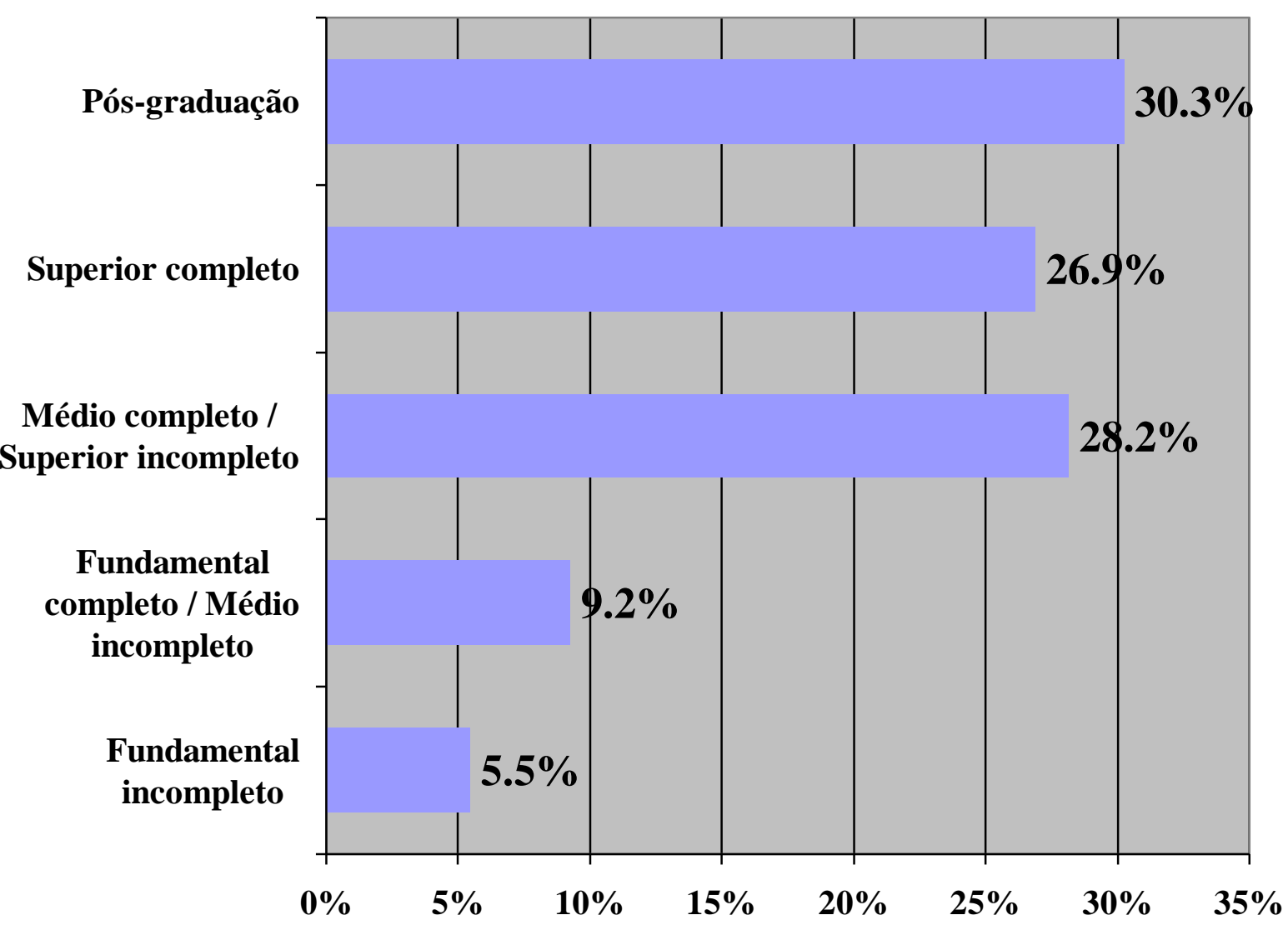

\begin{tabular}{|l|c|c|}
\hline \multicolumn{1}{|c|}{ Grau de instrução } & n & \% \\
\hline Fundamental incompleto & 13 & $5,5 \%$ \\
\hline Fundamental completo / Médio incompleto & 22 & $9,2 \%$ \\
\hline Médio completo / Superior incompleto & 67 & $28,2 \%$ \\
\hline Superior completo & 64 & $26,9 \%$ \\
\hline Pós-graduação & 72 & $30,3 \%$ \\
\hline
\end{tabular}

Gráfico 8 - Características demográficas da amostra: grau de instrução FONTE: Elaborado pelo autor. 


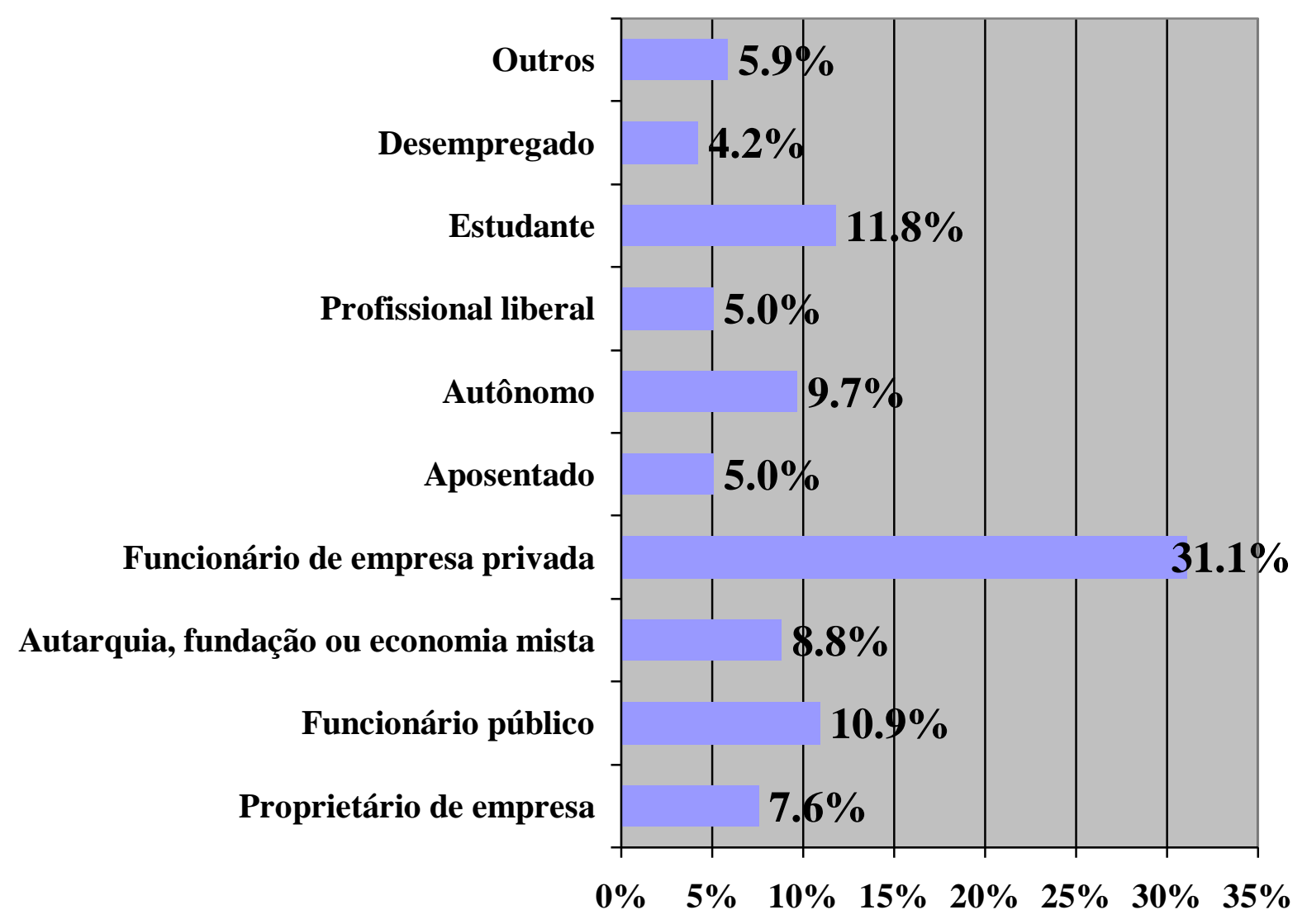

\begin{tabular}{|l|c|c|}
\hline \multicolumn{1}{|c|}{ Ocupação } & $\mathbf{n}$ & \% \\
\hline Proprietário de empresa & 18 & $7,6 \%$ \\
\hline Funcionário público & 26 & $10,9 \%$ \\
\hline Func. de autarquia, fundação ou economia mista & 21 & $8,8 \%$ \\
\hline Funcionário de empresa privada & 74 & $31,1 \%$ \\
\hline Aposentado & 12 & $5,0 \%$ \\
\hline Autônomo & 23 & $9,7 \%$ \\
\hline Profissional liberal & 12 & $5,0 \%$ \\
\hline Estudante & 28 & $11,8 \%$ \\
\hline Desempregado & 10 & $4,2 \%$ \\
\hline Outros & 14 & $5,9 \%$ \\
\hline
\end{tabular}

Gráfico 9 - Características demográficas da amostra: ocupação FONTE: Elaborado pelo autor. 


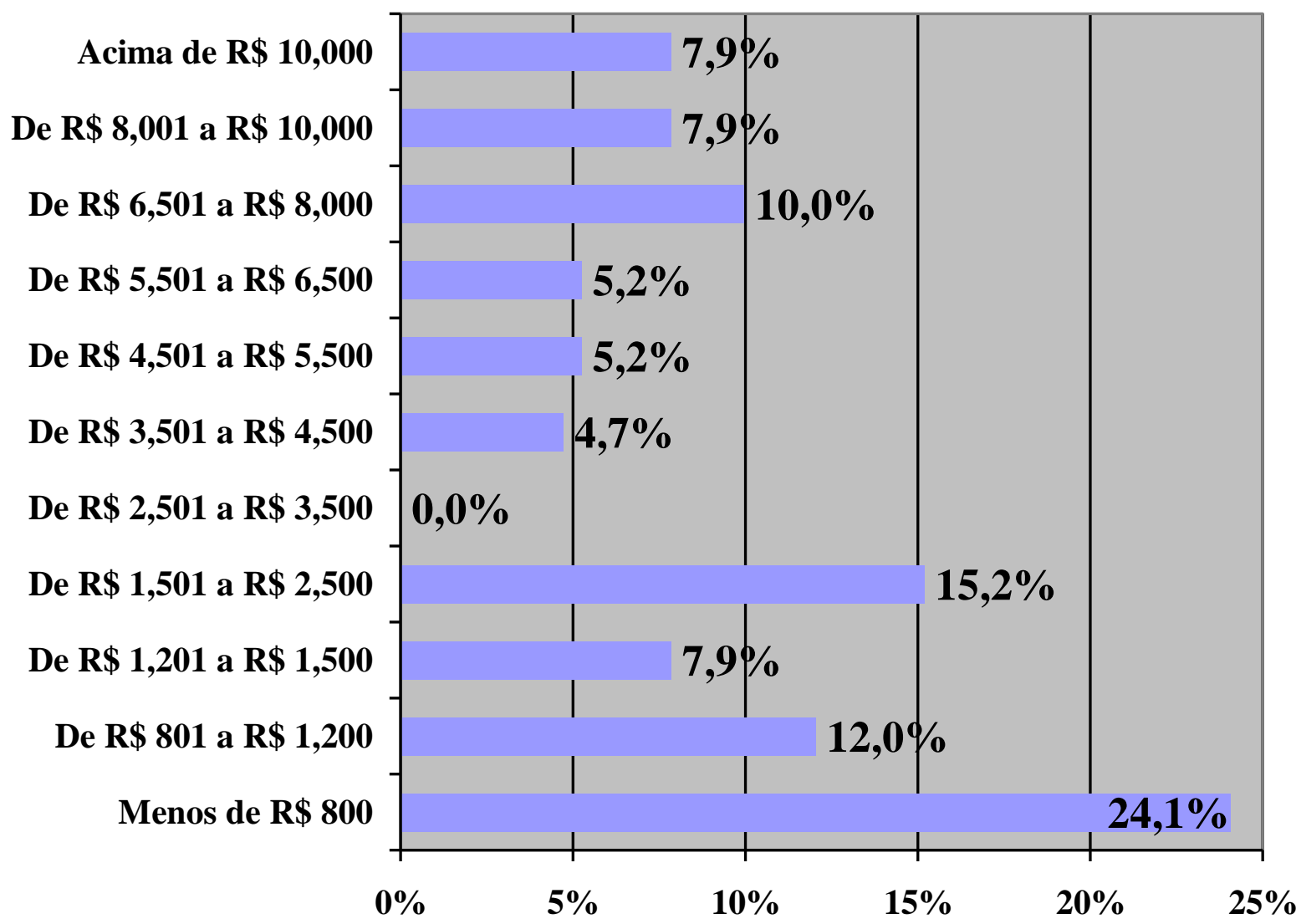

\begin{tabular}{|c|c|c|}
\hline Renda & $\mathbf{n}$ & $\%$ \\
\hline Menos de R $\$ 800$ & 46 & $24,1 \%$ \\
\hline De $\mathrm{R} \$ 801$ a $\mathrm{R} \$ 1.200$ & 23 & $12,0 \%$ \\
\hline De $R \$ 1.201$ a $R \$ 1.500$ & 15 & $7,9 \%$ \\
\hline De $R \$ 1.501$ a $R \$ 2.500$ & 29 & $15,2 \%$ \\
\hline De $R \$ 2.501$ a $R \$ 3.500$ & 0 & $0,0 \%$ \\
\hline De $R \$ 3.501$ a $R \$ 4.500$ & 9 & $4,7 \%$ \\
\hline De $R \$ 4.501$ a $R \$ 5.500$ & 10 & $5,2 \%$ \\
\hline De $R \$ 5.501$ a $R \$ 6.500$ & 10 & $5,2 \%$ \\
\hline De $R \$ 6.501$ a $R \$ 8.000$ & 19 & $10,0 \%$ \\
\hline De $\mathrm{R} \$ 8.001$ a $\mathrm{R} \$ 10.000$ & 15 & $7,9 \%$ \\
\hline Acima de $\mathrm{R} \$ 10 ., 000$ & 15 & $7,9 \%$ \\
\hline
\end{tabular}

Gráfico 10 - Características demográficas da amostra: renda pessoal FONTE: Elaborado pelo autor. 


\subsection{Preparação dos dados}

Após coletados os dados, foi realizado um procedimento de ponderação estatística para que a amostra coletada pudesse refletir as mesmas proporções de distribuição da população usuária de Internet no Brasil, no que se refere às características de distribuição por sexo, faixa etária e renda. Para tal, foram usados como referências os perfis dos usuários de Internet no Brasil apontados pela ComScore (2008) e pelo IBOPE (2008), com base no perfil da população usuária ativa de Internet, considerando tanto o acesso doméstico quanto o acesso no trabalho e em locais públicos.

A tabela 5 abaixo aponta a distribuição usada como referência para a ponderação dos dados da amostra coletada.

Tabela 5 - Distribuição demográfica usada para ponderação dos dados da amostra

\begin{tabular}{lcc}
\hline Sexo & Total & \% \\
\hline Masculino & 14,597 & $52 \%$ \\
Feminino & 13,546 & $48 \%$ \\
\hline Faixa Etária & & Total \\
\hline Até 20 anos & 8,572 & $30 \%$ \\
De 21 a 30 anos & 9,275 & $33 \%$ \\
De 31 a 40 anos & 6,040 & $21 \%$ \\
De 41 a 50 anos & 2,673 & $9 \%$ \\
De 51 a 60 anos & 1,187 & $4 \%$ \\
Mais de 60 anos & 396 & $1 \%$ \\
\hline
\end{tabular}

\begin{tabular}{lcc}
\hline Escolaridade & Total & $\%$ \\
\hline Ensino fundamental incompleto & 3,943 & $14 \%$ \\
Ensino fundamental completo / Ensino médio incompleto & 5,040 & $18 \%$ \\
Ensino médio completo / Ensino superior incompleto & 12,698 & $45 \%$ \\
Ensino superior completo & 4,584 & $16 \%$ \\
Pós-graduação & 1,877 & $7 \%$ \\
\hline
\end{tabular}

FONTE: ComScore Media Metrix, relatório de dezembro de 2008, Ibope TGI Brasil - fev/08 a jul/08 - 11 mercados. 
Supondo que as probabilidades de resposta dentro de cada um destes perfis utilizados para ponderação sejam os mesmos da população que representam, podemos proceder de maneira usual com as análises estatísticas.

Desta forma, embora devam ser consideradas as limitações decorrentes do fato do método de coleta de dados não ser rigorosamente probabilístico, as análises dos dados da amostra podem ser conduzidas levando em consideração o peso e a distribuição do perfil da população geral usuária de Internet no Brasil, e não a distribuição encontrada no levantamento dos dados, que refletiria apenas o perfil do usuário do serviço de busca do portal no momento em que foram veiculadas as chamadas de convite para o questionário.

Evidentemente, como esta suposição é passível de questionamento e não pode ser verificada neste estudo, as interpretações tradicionais dos resultados feitas no decorrer do trabalho devem ser analisadas com cautela.

\subsection{Análise dos resultados - Objetivo específico 1}

O primeiro objetivo específico consiste em apontar os fatores motivadores e inibidores da compra online. Para tal, foi realizada uma uma regressão logística com o objetivo de verificar a importância de cada um dos elementos avaliados (facilidade de acesso, preço, informação, segurança, conveniência, socialização e afetividade) e a avaliação média do meio online e das lojas físicas para cada fator.

A regressão logística é uma técnica estatística multivariada que tem como objetivo permitir a aferição da probabilidade da ocorrência de um evento pela relação dos dados coletados à curva logística, e a identificação das características dos elementos associados à variável independente (HAIR, 2005).

Outro aspecto importante a ser destacado é o fato de que a regressão logística é um modelo linear geral usado para regressão binomial. Como outras formas de análise de regressão, ela faz uso de diversas variáveis preditoras que podem ser tanto numéricas ou de categoria. É uma técnica usada extensivamente em aplicações de marketing como forma de prever a 
propensão de compra dos consumidores para determinados produtos (AGRESTI, 2002; HILBE, 2009), o que vem ao encontro dos objetivos propostos no presente trabalho.

\subsubsection{Especificação matemática}

Hilbe (2009) revela que a regressão logística analisa dados binomiais distribuídos na seguinte forma:

$$
Y i \sim B\left(n_{i}, p_{i}\right), \text { para } 1, \ldots m
$$

Onde o número de $n$ é conhecido e a probabilidade de sucesso $p$ é desconhecida. O modelo ainda propõe que para cada teste (valor de $i$ ) há um conjunto de variáveis explicativas que pode informar a probabilidade final (HILBE, 2009). Estas variáveis podem ser encaradas como sendo em um vetor $k$ denominado $X i$, dando a seguinte forma ao modelo:

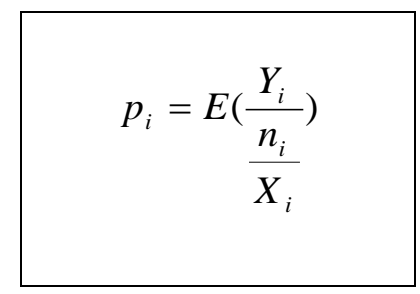

Os logits da probabilidade binomial desconhecida são, então, modelados como uma função linear de $X_{i}$ (HILBE, 2009).

$$
\operatorname{Logit}\left(p_{i}\right)=\ln \left(\frac{p_{i}}{1-p_{i}}\right)=\beta_{0}+\beta_{1} x_{1, i}+\ldots+\beta_{k} x_{k, 1}
$$

Um elemento específico de $X_{\mathrm{i}}$ pode ser determinado para 1 para todos os $i$, para inclusão do intercepto no modelo. Os parâmetros desconhecidos $\beta_{1}$ são normalmente estimados pela probabilidade máxima usando um método comum a todos os modelos gerais lineares (HILBE, 2009). 
A interpretação das estimativas do parâmetro $\beta_{1}$ é complementar ao efeito de relação de odds para uma mudança de unidade na variável explicativa. No caso de variáveis explicativas dicotômicas, $e^{\beta}$ é a estimativa da relação de odds para indicar a relação das variáveis (HILBE, 2009).

Com isto, o modelo adquire a seguinte formulação:

$$
p^{i}=\left(\frac{1}{1+e^{-(\beta 0+\beta 1 x 1, i+\ldots+\beta k k k, 1)}}\right)
$$

Esta formulação é normalmente denominada single-layer perceptron ou single-layer rede neural artificial (HILBE, 2009).

Para o presente trabalho, foi realizado o processamento dos dados com o software SPSS, e a tabela 6 apresenta um sumário dos resultados da regressão e da avaliação dos fatores obtido na coleta dos dados.

A tabela com o processamento completo dos dados foi incluída no apêndice do trabalho. 
Tabela 6 - Resumo da avaliação dos elementos motivadores e inibidores de compra online

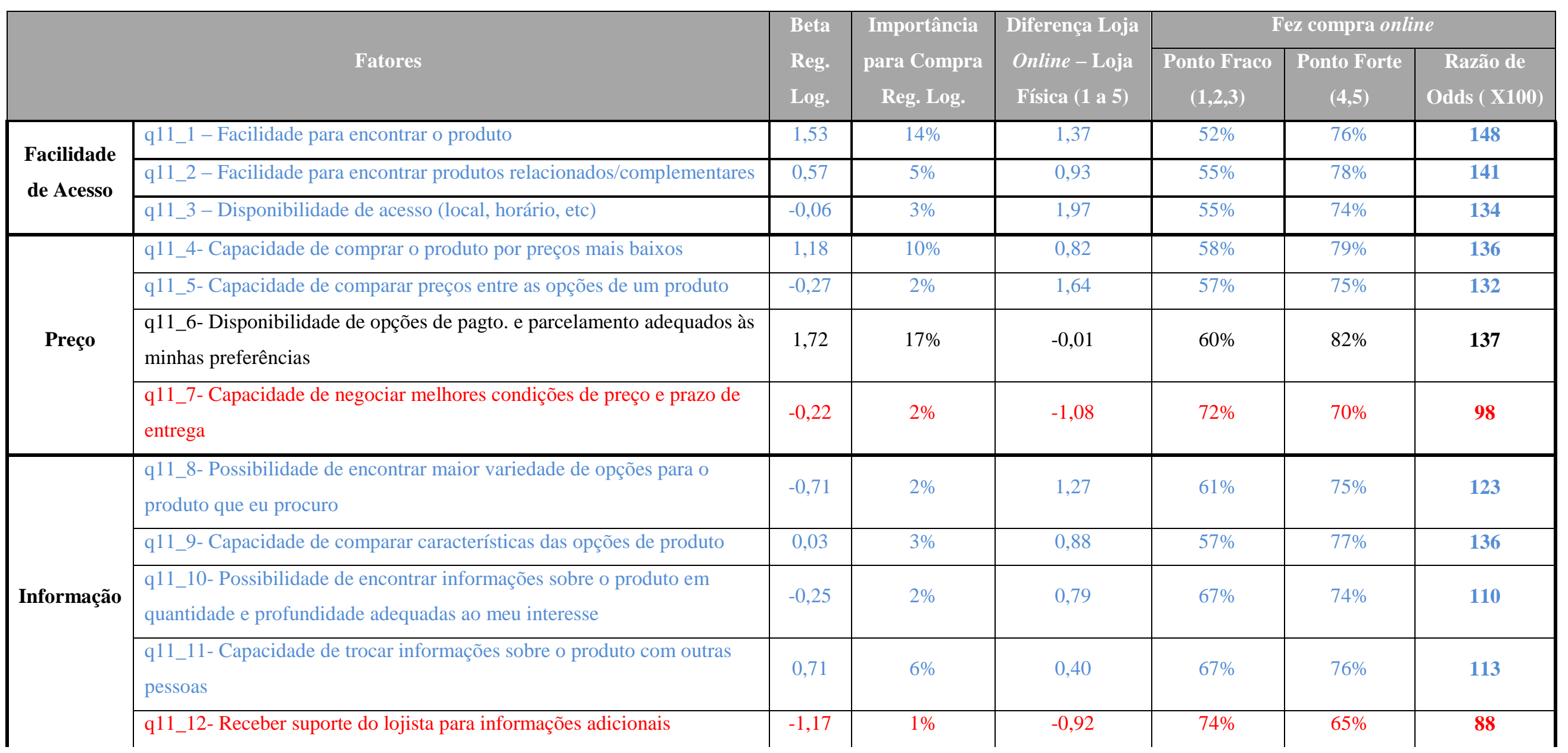




\begin{tabular}{|c|c|c|c|c|c|c|c|}
\hline \multirow{2}{*}{\multicolumn{2}{|c|}{ Fatores }} & \multirow[b]{2}{*}{$\begin{array}{l}\text { Beta } \\
\text { Reg. } \\
\text { Log. }\end{array}$} & \multirow[b]{2}{*}{$\begin{array}{c}\text { Importância } \\
\text { para Compra } \\
\text { Reg. Log. }\end{array}$} & \multirow{2}{*}{$\begin{array}{c}\text { Diferença } \\
\text { Loja Online } \\
\text { - Loja Física } \\
\text { (1 a 5) }\end{array}$} & \multicolumn{3}{|c|}{ Fez compra online } \\
\hline & & & & & $\begin{array}{l}\text { Ponto Fraco } \\
\qquad(1,2,3)\end{array}$ & $\begin{array}{l}\text { Ponto Forte } \\
\qquad(4,5)\end{array}$ & $\begin{array}{c}\text { Razão de } \\
\text { Odds ( X100) }\end{array}$ \\
\hline \multirow{3}{*}{ Segurança } & $\begin{array}{l}\text { q11_13 - Sentimento de segurança na disponibilização de informações } \\
\text { pessoais (RG, CPF, etc) para a realização da compra }\end{array}$ & 0,75 & $6 \%$ & $-1,49$ & $71 \%$ & $73 \%$ & 102 \\
\hline & $\begin{array}{l}\text { q11_14 - Sentimento de segurança na disponibilização de informações } \\
\text { de cartão de crédito ou outras formas eletrônicas de pagamento }\end{array}$ & $-0,91$ & $1 \%$ & $-1,41$ & $71 \%$ & $72 \%$ & 101 \\
\hline & $\begin{array}{l}\text { q11_15 - Disponibilização de opções de pagamento não-eletrônicas } \\
\text { (como cheque, boleto bancário, etc) }\end{array}$ & 0,46 & $5 \%$ & $-0,80$ & $68 \%$ & $76 \%$ & 112 \\
\hline \multirow{3}{*}{ Conveniência } & q11_16- Necessidade de deslocamento para realização de compra & 0,10 & $3 \%$ & 1,84 & $62 \%$ & $74 \%$ & 118 \\
\hline & q11_17- Realização da compra com rapidez & $-0,04$ & $3 \%$ & 1,15 & $66 \%$ & $74 \%$ & 111 \\
\hline & q11_18-Efetuação da compra de forma prática e conveniente & $-1,17$ & $1 \%$ & 0,97 & $71 \%$ & $71 \%$ & 100 \\
\hline \multirow{3}{*}{$\begin{array}{l}\text { Socialização } \\
\text { e Afetividade }\end{array}$} & q11_19- Recebimento de tratamento personalizado & 0,56 & $5 \%$ & $-0,97$ & $76 \%$ & $60 \%$ & 79 \\
\hline & q11_20-Capacidade de tocar ou sentir o produto a ser comprado & $-3,62$ & $0 \%$ & $-2,47$ & $76 \%$ & $35 \%$ & 46 \\
\hline & q11_21- Capacidade de tornar o processo de compra prazeroso & 0,69 & $6 \%$ & $-0,94$ & $69 \%$ & $77 \%$ & 112 \\
\hline
\end{tabular}

FONTE: Elaborado pelo autor. 
A coluna Beta Reg. Log. aponta os betas obtidos com a regressão logística e na coluna ao lado há um indicador percentual de quanto cada uma das variáveis consegue explicar a importância do elemento de análise para a decisão do meio (online ou loja física) para a compra online.

Com base na informação da coluna "Diferença Loja Online - Loja Física", que representa uma subtração entre a média das avaliações do meio online e das lojas físicas para cada construto, foram marcadas em vermelho as linhas que apontam relação favorável às compras em lojas físicas; em azul, aquelas favoráveis às compras em lojas online; e em preto a que não apresenta afinidade específica com um dos meios. Tomados os construtos de forma agrupada para análise dos principais conjuntos e sua importância na decisão do meio de compra, há alguns aspectos interessantes que podem ser observados.

Alinhada à expectativa e aos resultados de trabalhos anteriores verificados nas referências encontradas na literatura da área, o principal fator influenciador na decisão do meio para a efetuação da compra é o grupo "Preço", que representa 31,9\% da importância na decisão do meio de compra no processo de avaliação indicada pela regressão logística (soma dos índices "Importância para Compra Reg. Log.” dos construtos do grupo "Preço”).

Quando somadas as médias de avaliação dos construtos deste grupo, ponderadas pela importância relativa de cada um dada pela regressão logística (multiplicação dos números obtidos na coluna "Diferença Loja Online - Loja Física" pela informação da coluna "Importância para Compra Reg. Log." e somadas dentro dos grupos de fatores, como "Preço", "Segurança", etc.), a avaliação média do meio online é apenas +0,28 maior do que a das lojas físicas, na escala de 1 a 5, o que aponta um favorecimento para o meio Internet, ainda que não seja de forma acentuada.

O resultado é coerente com a falta de uma tendência forte de preferência por um dos meios quando a avaliação em questão é realizada em relação ao preço (DONTHU, GARCIA, 1999; GREWAL et al, 2003) e, individualmente, a facilidade na comparação de preços entre as diferentes opções de lojas para um mesmo produto (+1,64 na coluna "Diferença Loja Online Loja Física") é o fator que mais favorece a Internet, o que é consistente com os trabalhos conduzidos em experimentos na área (BAKOS, 1997; LYNCH, ARIELY, 2000). 
Por outro lado, ainda dentro deste mesmo critério, a capacidade de negociar melhores condições de preço e prazo é o fator que mais favorece as lojas físicas $(-1,08)$, o que reflete o ainda incipiente uso de tecnologias de comunicação em tempo real por parte dos varejistas online (como sistemas de comunicação baseados em voz, ou chats), constituindo uma das principais apostas do setor para aumentar o relacionamento e a possibilidade de negociação com os clientes do meio online.

O segundo fator de maior importância na decisão do meio é a facilidade de acesso, com peso de $22,5 \%$ na avaliação do meio de compra (novamente pela soma da importância de cada construto indicada pela informação da coluna "Importância para Compra Reg. Log."). Considerando que a soma das médias de avaliação dos meios soma $+1,34$ em favor da Internet, este fator constitui individualmente o de maior favorecimento do meio online (delta de $+0,30$ quando multiplicada a diferença de avaliação verificada na coluna "Diferença Loja Online - Loja Física" pelo peso do fator dado pela informação na coluna "Importância para Compra Reg. Log.").

Uma indicação da importância da facilidade de acesso para os usuários que realizam compra online pode ser verificada pela razão de odds entre o percentual de usuários que realizaram compras online entre quem considera este fator um ponto forte da Internet (avaliação 4 ou 5 neste quesito), e o percentual de usuários que realizaram compras online, mas que não consideram este um ponto forte do meio (avaliações 1, 2 ou 3 neste quesito). A média da razão de odds no grupo facilidade de acesso é 141, representando $41 \%$ mais provável encontrar um comprador online entre quem valoriza este aspecto na compra online, do que entre aqueles que não valorizam este aspecto, coerente com os trabalhos verificados na literatura (BECKER, 2007; HOFFMAN et al, 2002; LYNCH, ARIELY, 2000; WOLFINBARGER, GILLY, 2004).

A tabela 7 mostra um resumo da importância de cada grupo de fatores, a soma da diferença entre as médias das avaliações entre loja online e loja física ponderadas pela importância de cada fator, e o delta que representa o produto entre os dois elementos. 
Tabela 7 - Importância dos fatores na decisão do meio de compra

\begin{tabular}{lccc}
\hline \multicolumn{1}{c}{ Grupo } & $\begin{array}{c}\text { Importância para } \\
\text { Compra }- \text { Reg. Log. }\end{array}$ & $\begin{array}{c}\text { Soma das diferenças ponderadas } \\
\text { = Loja } \text { Online }- \text { Loja Física }\end{array}$ & Delta \\
\hline Facilidade de Acesso & $22,5 \%$ & $+1,34$ & $+0,30$ \\
Preço & $31,9 \%$ & $+0,28$ & $+0,09$ \\
Informação & $14,3 \%$ & $+0,58$ & $+0,08$ \\
Segurança & $12,6 \%$ & $-1,21$ & $-0,15$ \\
Conveniência & $7,3 \%$ & $+1,45$ & $+0,11$ \\
Socialização e Afetividade & $11,5 \%$ & $-0,97$ & $-0,11$ \\
& $\mathbf{1 0 0 , 0 \%}$ & $\mathbf{+ 1 , 4 7}$ & $+\mathbf{0 , 3 1}$ \\
\hline
\end{tabular}

FONTE: Elaborado pelo autor .

Novamente alinhado às expectativas da literatura, o grupo Informação apontou um favorecimento do meio online de $+0,58$, explicável pela variedade de opções e informações sobre o produto desejado $(+1,27)$, e em menor escala, pela capacidade de comparar as diferentes opções $(+0,88)$, quantidade e profundidade das informações disponíveis $(+0,79)$ e a capacidade de trocar informações com outros compradores $(+0,40)$. O suporte do lojista com informações adicionais continua sendo o aspecto mais deficiente $(-0,92)$. O peso global do grupo na decisão representou $12,6 \%$, constituindo um favorecimento ponderado ao meio online de $+0,08$.

A segurança transacional foi o fator de pior avaliação do meio online, resultando em uma avaliação média ponderada de $-1,21$ pontos para o meio online em relação às lojas físicas, mas representa um fator de peso mais baixo $(12,6 \%)$ em relação a determinados aspectos que representam favorecimento econômico (como, por exemplo, preço com 22,5\%) ou comodidade (com facilidade de acesso - 22,5\%), e fica em um patamar próximo aos quesitos associados à experiência de compra, como informação $(14,3 \%)$ e socialização e afetividade $(11,5 \%)$

A relativa baixa importância do fator segurança se destaca em relação a trabalhos anteriores relativamente recentes realizados na área (ARNOLD et al, 2007; EINWILLER, 2003). Embora a percepção sobre a segurança no envio de dados e o sentimento de segurança do usuário para disponibilizar suas informações apresentem a maior diferença de avaliação em favor das lojas físicas, o que denota que o sentimento de insegurança na efetuação da compra 
pela Internet permanece, os aspectos mais funcionais da compra parecem representar um papel mais importante na escolha do meio.

Embora pela restrição de escopo deste trabalho não seja possível identificar as causas deste resultado, a investigação das causas e relações associadas a este fenômeno constitui uma excelente oportunidade para trabalhos futuros na área.

Os elementos relacionados à socialização e afetividade apresentam $11,5 \%$ de peso no processo decisório, e as médias de avaliação apontam claramente um favorecimento das lojas físicas $(-0,97)$, consistente com a lógica de que estes são elementos tradicionalmente associados ao processo de vendas pessoal e de acordo com os trabalhos de Childers et al (2001) e Nicholson et al (2002), e a despeito dos contínuos investimentos que as grandes redes de varejo online vêm realizando no desenvolvimento de ferramentas de interação entre a equipe de vendas e potenciais consumidores e mesmo entre grupos de clientes no meio digital.

Por fim, o grupo Conveniência apresentou o menor peso relativo no processo decisório, com 7,3\%, explicável possivelmente pela captação de parte da importância pelo grupo facilidade de acesso (22,5\%), mas foi o que apresentou a maior diferença favorável às lojas online, consistente com a literatura (ANDERSON, 2006; COLWELL et al, 2008; FANCIS, WHITE, 2004), embora na ponderação pela importância do fator isto represente um delta de apenas $+0,11$ de favorecimento, que apenas equilibra a perda, por exemplo, em socialização e afetividade $(-0,11)$.

Tomados em conjunto, os resultados denotam uma avaliação mais favorável às lojas online dentro de um processo racional de avaliação dos meios, quando o resultado é ponderado pela importância de cada fator.

O gráfico 11 apresenta uma matriz de avaliação do meio online plotando cada fator de avaliação por sua importância no processo de decisão e pela média de avaliação comparativa ao das lojas físicas. 


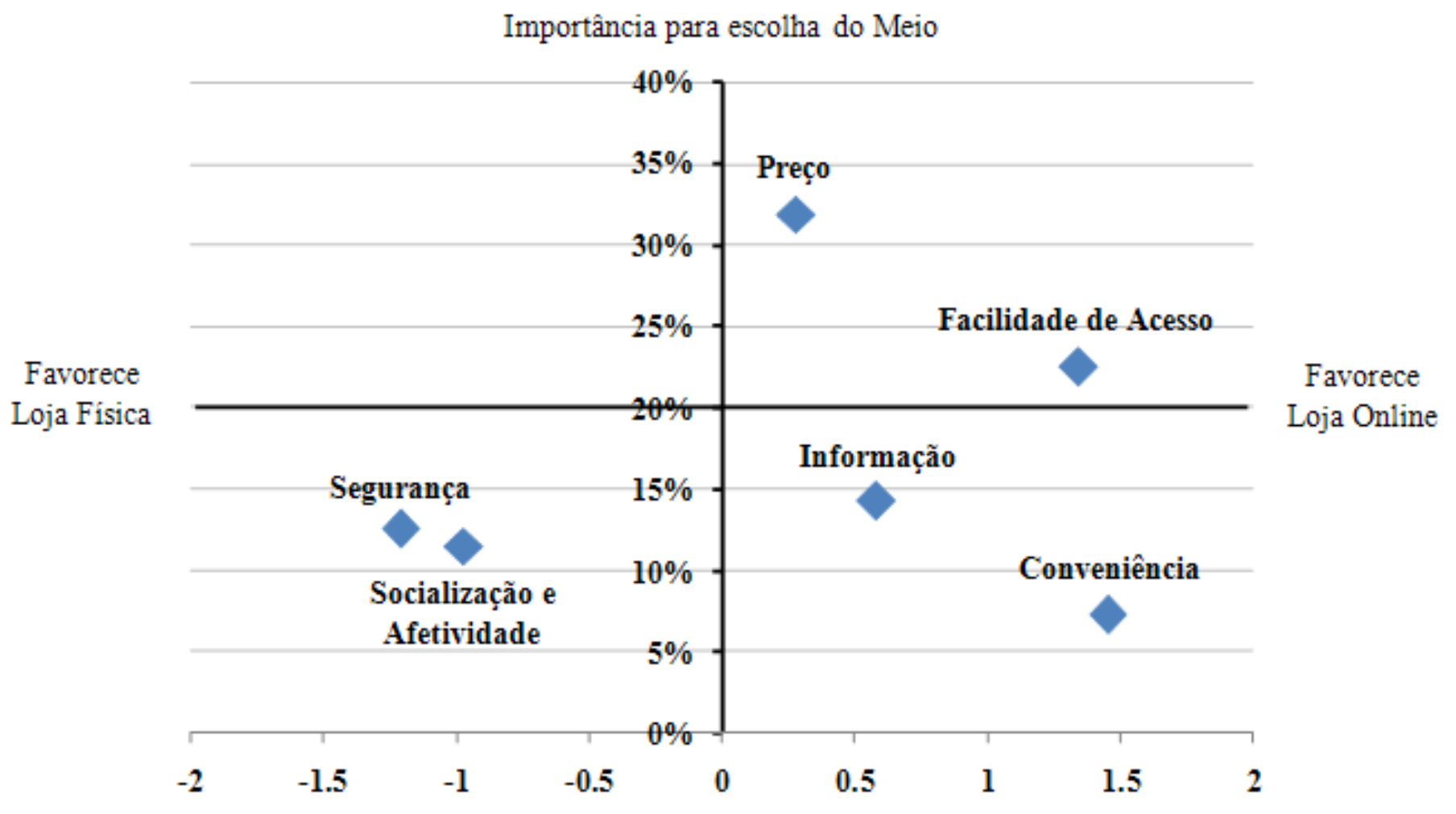

Gráfico 11 - Matriz de importância e avaliação do meio FONTE: Elaborado pelo autor.

A análise matricial apresenta a relação de favorecimento entre os fatores, permitindo identificar claramente que aqueles que são mais determinantes para a decisão do meio de compra ("Preço" e "Facilidade de acesso") estão posicionados no quadrante favorável ao meio online, ainda que no caso do grupo "Preço", a percepção de vantagem das lojas online em relação às lojas físicas seja relativamente pequeno.

Entre os que poderiam ser classificados como os diferenciais neste processo de decisão, "Segurança", e o grupo "Socialização e afetividade" favorecem às lojas físicas, e "Informação" e "Conveniência" favorecem à escolha pelas lojas online. 


\subsection{Análise dos resultados - Objetivo específico 2}

O segundo objetivo específico do trabalho consiste na identificação da existência ou não da relação entre a experiência de uso da Internet e a frequência de compra pelo meio. A hipótese era de que quanto maior o tempo de uso da rede, maior seria a frequência de compra pelo meio Internet, em função da curva de aprendizado e o conforto crescente com a exploração das diferentes oportunidades de uso existentes na Internet.

Para cumprir tal objetivo, foram trabalhadas no presente estudo duas vertentes diferentes de mensuração da experiência no uso da Internet: o tempo de contato com a rede, medido pelo momento em que houve o primeiro contato do usuário com a Internet; e a quantidade média de horas de uso da Internet por semana, que embora seja uma indicação diretamente associada à intensidade de uso, é um vetor fundamental no processo de aceleração do conhecimento do uso das ferramentas da Web.

Os dados relativos às duas vertentes foram então cruzados com as informações relativas à quantidade de compras realizadas nos 12 meses anteriores à pesquisa, e também à intenção do usuário de realizar compras nos 12 meses seguintes. Embora objetivamente o intuito específico fosse identificar a relação com as compras já efetuadas, a oportunidade de avaliar a informação também à luz da intenção de compra constitui um rico complemento para identificar a influência da experiência na atitude do usuário em relação à compra online, tendo assim um escopo mais amplo.

Ainda como complementação do esforço de identificação de associação entre as variáveis, foi realizada a medição do grau de correspondência e significação entre os dois elementos por meio do teste de coeficiente de Kendall tau.

O coeficiente de correlação Kendall tau (ou coeficiente Kendall tau, Kendall $\tau$, ou teste tau) é um teste estatístico não-paramétrico usado para medir o grau de correspondência entre duas listagens, medindo a significância da correspondência (ABDI, 2007; HAIR et al, 2005). 
A opção por este teste deve-se ao fato de que ele permite medir a força do relacionamento entre duas variáveis de forma direta e de fácil compreensão, apresentando vantagens de cunho pedagógico e prático em relação a outros coeficientes usados com o mesmo intuito, como o coeficiente Spearman, por exemplo (NOETHER, apud ABDI, 2007).

O coeficiente Kendall tau é definido pela seguinte equação:

$$
\tau=\frac{n_{c}-n_{d}}{1 / 2 n(n-1)}
$$

Onde $n_{c}$ é o número de pares de dados onde há concordância, e $n_{d}$ é o número de pares de dados onde há discordância (ABDI, 2007).

Como o numerador representa a diferença entre o total de pares concordantes e discordantes, quanto maior o número, maior a tendência de que haja consistência entre as variáveis envolvidas na análise (ABDI, 2007).

Abdi (2007) ainda aponta que analisando-se o resultado final do coeficiente, os resultados podem variar entre -1, caso haja uma perfeita associação negativa entre as variáveis, e 1, caso haja perfeita associação positiva entre os pares de dados. O resultado 0 representa ausência de associação.

No presente trabalho, optou-se pelo uso do coeficiente Kendall tau-b, que mede a força de associação em uma tabulação cruzada quando as variáveis são ordinais, fazendo ajuste para igualdades em tabelas com o mesmo número de variáveis.

A tabela 8 apresenta os resultados dos coeficientes de Kendall tau-b para as variáveis consideradas na análise do objetivo específico 2 . 
Tabela 8 - Kendall's tau_b - Correlation Coefficient - OE 2

q1 - Há quanto tempo foi seu q2- Em média, quantas horas por primeiro contato com a semana você passa acessando a Internet? Internet?

q6 - Especificamente nos últimos 12 meses, quantas compras você 0.148 0.201 realizou pela Internet? q8 - Em uma escala de 1 a 5 , como você avalia sua intenção de realizar compras pela Internet nos próximos 12 meses?

Em verde - Significativo a 5\%; Em azul - Significativo a 1\%

FONTE: Elaborado pelo autor.

Na sequência, partindo do tempo de contato do usuário com a Internet, a tabela 9 descreve o resultado do cruzamento desta informação com a quantidade de compras realizadas pelo usuário nos 12 meses anteriores, e com a intenção de compra para os 12 meses posteriores à realização da pesquisa.

Tabela 9 - Cruzamento de informações entre experiência de uso da Internet, comportamento de compra e intenção de compra (\% dos respondentes)

q1 - Há quanto tempo foi seu primeiro contato com a Internet?

\begin{tabular}{c|cccccc}
$\%$ Coluna & Menos de 1 & Entre 1 e 2 & Entre 2 e 3 & Entre 3 e 4 & Entre 4 e 5 & Mais de 5 \\
\cline { 2 - 4 } & $\begin{array}{c}\text { ano } \\
\text { anos }\end{array}$ & anos & anos & anos & anos
\end{tabular}

q6 - Especificamente nos últimos 12 meses, quantas compras você realizou pela Internet?

Não comprei

De 1 a 3 vezes

De 3 a 5 vezes

Mais de 5 vezes

Razão de Odds

$\begin{array}{|cccccc|}0 \% & 15 \% & 14 \% & 34 \% & 37 \% & 12 \% \\ 83 \% & 79 \% & 46 \% & 66 \% & 62 \% & 49 \% \\ 17 \% & 2 \% & 0 \% & 0 \% & 0 \% & 16 \% \\ 0 \% & 3 \% & 40 \% & 0 \% & 1 \% & 23 \% \\ 20 & 6 & 65 & 0 & 1 & 63\end{array}$

q8 - Como você avalia sua intenção de realizar compras pela Internet nos próximos 12 meses?

\begin{tabular}{l|cccccc|}
\hline Muito improvável & $0 \%$ & $0 \%$ & $5 \%$ & $0 \%$ & $0 \%$ & $16 \%$ \\
Improvável & $0 \%$ & $8 \%$ & $0 \%$ & $68 \%$ & $74 \%$ & $3 \%$ \\
Talvez compre & $0 \%$ & $54 \%$ & $47 \%$ & $0 \%$ & $3 \%$ & $18 \%$ \\
Provável & $38 \%$ & $0 \%$ & $9 \%$ & $0 \%$ & $15 \%$ & $21 \%$ \\
Muito provável & $62 \%$ & $38 \%$ & $40 \%$ & $32 \%$ & $8 \%$ & $41 \%$ \\
Dif Top 2- & $\mathbf{1 0 0}$ & $\mathbf{- 2 5}$ & $\mathbf{- 3}$ & $\mathbf{- 3 7}$ & $\mathbf{- 5 4}$ & $\mathbf{2 5}$ \\
Bottom 3 & & & & & \\
\hline
\end{tabular}

FONTE: Elaborado pelo autor. 
Embora os usuários com mais de 5 anos de experiência no uso da Internet apresentem uma relação de alta frequência de compras verificada nos 12 meses anteriores, a irregularidade verificada na distribuição dos dados coletados dificulta a visualização de um padrão claro de correlação entre o aumento do tempo do uso e a quantidade de compras realizadas em lojas online.

O coeficiente de Kendall tau-b aponta associação positiva de 0,148 entre tempo de uso de Internet e quantidade de compras realizadas pela rede, significativo ao nível 5\%.

Ainda que a associação seja positiva, a razão de odds que pode ser verificado entre os dois níveis superiores de quantidade de compra e os dois inferiores apresentam respectivamente 0 e 1 nos grupos "Entre 3 e 4 anos" e "Entre 4 e 5 anos"; inferiores às razões de odds observadas nos 3 níveis iniciais, que apresentam 20 ("Menos de 1 ano"), 6 ("Entre 1 e 2 anos"), e 65 ("Entre 2 e 3 anos"), o que demonstra uma associação relativamente frágil entre as variáveis.

Os resultados parecem ser menos incisivos do que os conceitos que suportaram a formulação da hipótese deste trabalho, e também em relação aos resultados de estudos anteriores realizados com usuários americanos e europeus, que apontaram relação positiva mais forte (com coeficientes maiores e relações mais claras) entre a experiência de uso na Internet (no mesmo sentido adotado nesta primeira vertente do estudo - de tempo total a partir do primeiro contato com a Internet) e a propensão a usá-la para compra de bens e serviços (BECKER, 2007; CORBITT et al, 2003; KIM et al, 2000).

Como não há referência anterior na literatura de estudos realizados com usuários brasileiros, e as outras informações coletadas nesta pesquisa não permitem traçar outros paralelos a respeito dos resultados verificados, não é possível justificar a diferença nos resultados encontrados, mas como hipótese, o resultado que indica apenas uma pequena associação favorável entre experiência de uso e compras pela Internet pode incutir uma possível falta de adequação dos produtos comprados pelos usuários pesquisados com o meio online.

Estudos complementares com métodos de coleta mais adequados à realização de inferências seriam necessários para explorar e validar os resultados encontrados. 
A falta de padrão é mais clara e pode ser verificada no cruzamento entre o tempo de uso da Internet e a intenção de compra nos 12 meses seguintes à coleta dos dados. Entre aqueles com menos de 1 ano de uso da Internet, exatamente o grupo com menor experiência de uso da rede, a intenção de compra de produtos pela Web para os 12 meses seguintes totalizou 38\% como "Provável" e 62\% como "Muito provável", um patamar claramente superior de interesse do que aquele verificado entre os outros grupos de usuários.

O resultado também é confirmado pelo coeficiente Kendall tau-b de 0.019, que não apresenta associação significativa entre as variáveis.

Avaliando os resultados do cruzamento da segunda vertente adotada para a verificação da experiência de uso da Internet - baseada na intensidade de uso da rede - e a quantidade de compras realizadas nos 12 meses anteriores ao levantamento dos dados e, abaixo, a intenção de compra para os 12 meses seguintes, obtemos os seguintes resultados apresentados na tabela 10.

Tabela 10 - Cruzamento de informações entre a intensidade de uso da Internet, comportamento de compra e intenção de compra (\% dos respondentes)

q2 - Em média, quantas horas por semana você passa acessando a Internet?

\begin{tabular}{c|ccccc}
$\%$ Coluna & $\begin{array}{c}\text { Menos de 1 } \\
\text { hora }\end{array}$ & $\begin{array}{c}\text { De } 1 \text { a } 10 \\
\text { horas }\end{array}$ & $\begin{array}{c}\text { De } 10 \text { a 20 } \\
\text { horas }\end{array}$ & $\begin{array}{c}\text { De 20 a 30 } \\
\text { horas }\end{array}$ & $\begin{array}{c}\text { Mais de } 30 \\
\text { horas }\end{array}$
\end{tabular}

q6 - Especificamente nos últimos 12 meses, quantas compras você realizou pela Internet?

\begin{tabular}{l|ccccc} 
Não comprei & $27 \%$ & $22 \%$ & $21 \%$ & $2 \%$ & $9 \%$ \\
De 1 a 3 vezes & $54 \%$ & $52 \%$ & $61 \%$ & $52 \%$ & $50 \%$ \\
De 3 a 5 vezes & $4 \%$ & $13 \%$ & $9 \%$ & $22 \%$ & $11 \%$ \\
Mais de 5 vezes & $15 \%$ & $13 \%$ & $10 \%$ & $24 \%$ & 85 \\
Razão de Odds & 24 & 36 & 22 & 71
\end{tabular}

q8 - Como você avalia sua intenção de realizar compras pela Internet nos próximos 12 meses?

\begin{tabular}{l|ccccc|}
\hline Muito improvável & $0 \%$ & $6 \%$ & $17 \%$ & $30 \%$ & $8 \%$ \\
Improvável & $0 \%$ & $17 \%$ & $23 \%$ & $0 \%$ & $2 \%$ \\
Talvez compre & $27 \%$ & $16 \%$ & $25 \%$ & $10 \%$ & $27 \%$ \\
Provável & $39 \%$ & $24 \%$ & $7 \%$ & $22 \%$ & $15 \%$ \\
Muito provável & $34 \%$ & $37 \%$ & $28 \%$ & $39 \%$ & $47 \%$ \\
Razão de Odds & $\mathbf{2 7 2}$ & $\mathbf{1 5 5}$ & $\mathbf{5 5}$ & $\mathbf{1 5 1}$ & $\mathbf{1 6 7}$ \\
\hline
\end{tabular}

FONTE: Elaborado pelo autor. 
Diferentemente da primeira vertente de análise, em relação à intensidade de uso da Internet, foi possível identificar um padrão de associação entre esta variável e a evolução do comportamento de compras realizadas nos 12 meses anteriores ao levantamento. Foi factível identificar uma relação mais intensa de compra nos dois grupos de uso mais intenso da rede, como pode ser visto pela razão de odds de 85 para o público que usa Internet no grupo "de 20 a 30 horas por semana", e de 71 entre o público que usa Internet "mais de 30 horas por semana"; ambos bastante superiores aos níveis verificados nos grupos de menor tempo de uso semanal.

A associação positiva é confirmada e significativa ao nível $1 \%$ pelo coeficiente de Kendall tau-b, com resultado de 0.201 para o cruzamento entre os dados das duas variáveis.

Em relação ao cruzamento dos dados da intensidade de uso da Internet com a intenção de compra nos 12 meses seguintes à coleta dos dados, não pôde ser estabelecido nenhum padrão de comportamento em função da distribuição irregular dos respondentes, apresentando resultados elevados com relação à intenção de compra tanto entre o público com pouco tempo de uso semanal da Internet (razão de odds de 272 entre aqueles com "menos de 1 hora semanal") quanto nos grupos com uso mais intenso (razão de odds de 151 entre aqueles com uso "de 20 a 30 horas semanais", e de 167 entre os usuários com "mais de 30 horas semanais").

Na mesma linha, a faixa intermediária de intensidade de uso foi justamente a que apresentou a menor razão de odds (55) deste levantamento, o que reforça a percepção de falta de um padrão que permita estabelecer relação entre as variáveis.

A percepção com base na observação do cruzamento dos dados é confirmada pelo coeficiente 0.071 de Kendall tau-b, que não é significativo a nenhum dos níveis considerados neste estudo, e próximo ao nível zero, indicando completa ausência de associação entre as variáveis. 


\subsection{Análise dos resultados - Objetivo específico 3}

O terceiro objetivo específico do trabalho consiste na identificação da existência ou não de relação entre a satisfação com os produtos comprados anteriormente pela Internet e a intenção de compra futura pelo meio. A hipótese adotada no estudo é que a alta satisfação com as compras anteriores realizadas pela rede aumentaria a intenção de compra futura pela Web.

As técnicas aplicadas para esta análise seguiram a mesma lógica do objetivo específico 2 , fazendo um cruzamento entre a informação relativa à satisfação pós-compra para os produtos comprados na Internet, e a intenção de realização de compras em lojas online para o período dos 12 meses seguintes à participação na pesquisa.

Complementarmente, foi conduzido o teste de coeficiente de correlação Kendall tau-b para que fosse verificada a força de associação entre as variáveis de análise.

A tabela 11 apresenta o resultado do coeficiente de Kendall tau-b para as variáveis consideradas na análise do objetivo específico 3.

Tabela 11 - Kendall's tau_b - Correlation Coefficient - OE 3

q10 - Em relação às compras realizadas em lojas físicas, como você avalia sua satisfação com os produtos adquiridos pela Intenet?

q8 - Em uma escala de 1 a 5, como você avalia sua intenção de realizar compras pela Internet nos próximos 12 meses?

Em verde - Significativo a 5\%; Em azul - Significativo a 1\%

FONTE: Elaborado pelo autor. 
A tabela 12 exibe os resultados do cruzamento dos dados.

Tabela 12 - Relação entre satisfação pós-compra pela Internet e intenção de compra (\% dos respondentes)

\begin{tabular}{|c|c|c|c|c|c|}
\hline \multirow[b]{2}{*}{$\%$ Coluna } & \multicolumn{5}{|c|}{$\begin{array}{l}\text { q10 - Em relação às compras realizadas em lojas físicas, como você avalia sua } \\
\text { satisfação com os produtos adquiridos pela Internet? }\end{array}$} \\
\hline & $\begin{array}{c}\text { Muito } \\
\text { menos } \\
\text { satisfeito }\end{array}$ & $\begin{array}{c}\text { Menos } \\
\text { satisfeito }\end{array}$ & $\begin{array}{c}\text { Mesmo } \\
\text { nível de } \\
\text { satisfação }\end{array}$ & $\begin{array}{c}\text { Mais } \\
\text { satisfeito }\end{array}$ & $\begin{array}{l}\text { Muito mais } \\
\text { satisfeito }\end{array}$ \\
\hline \multicolumn{6}{|c|}{ q8 - Como você avalia sua intenção de realizar compras pela Internet nos próximos 12 meses? } \\
\hline Muito improvável & $1 \%$ & $14 \%$ & $16 \%$ & $13 \%$ & $3 \%$ \\
\hline Improvável & $28 \%$ & $11 \%$ & $9 \%$ & $5 \%$ & $0 \%$ \\
\hline Talvez compre & $48 \%$ & $43 \%$ & $22 \%$ & $3 \%$ & $0 \%$ \\
\hline Provável & $0 \%$ & $2 \%$ & $21 \%$ & $30 \%$ & $21 \%$ \\
\hline Muito provável & $23 \%$ & $30 \%$ & $33 \%$ & $50 \%$ & $76 \%$ \\
\hline Razão de Odds & 30 & 47 & 115 & 392 & 2.921 \\
\hline
\end{tabular}

FONTE: Elaborado pelo autor.

É claramente identificável a associação entre as duas variáveis, em que a satisfação com as compras realizadas anteriormente pela Internet exerce influência positiva na intenção do usuário de voltar a comprar pela rede.

A razão de odds obtida pela divisão da soma dos dois níveis superiores de intenção de compra ("Provável” e "Muito provável”) pela soma dos três níveis inferiores ("Muito improvável”, "Improvável" e "Talvez compre") e multiplicada por 100 aponta uma relação crescente direta entre os dois fatores, com 30 para o grupo que declara ficar "muito menos satisfeito" com as compras realizadas pela Internet; 47 para o grupo "menos satisfeito" com as compras online, 115 entre os que se declaram com o "mesmo nível de satisfação" nas compras online do que nas realizadas em lojas físicas; sobe para 392 entre os usuários "mais satisfeitos" com as compras online, e atinge 2.921 no grupo que se declara "muito mais satisfeito" com as compras realizadas pela Internet.

A associação positiva também é confirmada pelo coeficiente 0.259 de correlação no teste Kendall tau-b, significativo ao nível $1 \%$.

Embora nas referências da área não tenha sido encontrado nenhum trabalho específico sobre esta relação no meio online, o resultado verificado neste estudo confirma a literatura clássica 
de comportamento do consumidor que indica que as avaliações pós-consumo desempenham um papel preponderante na intenção de recompra do produto e do meio de realização da compra (BLACKWELL, 2005; FOLKES, 1984; MITTAL, KAMAKURA, 2001).

Uma possível justificativa para isto pode estar exatamente nos elementos mais favoráveis às compras em lojas online identificados no presente trabalho. Dois dos aspectos mais favoráveis (informação e preço) são justamente aqueles frequentemente apontados na literatura como relacionados a um processo de compra planejado, em que normalmente há maior envolvimento do comprador com o produto ou serviço comprado, e no qual o próprio processo de planejamento procura reduzir ao máximo a possibilidade de dissonância cognitiva pós-compra (BLACKWELL, 2005).

Desta forma, a satisfação pós-compra com os produtos adquiridos pela Internet seria provavelmente consequência de um processo de compra que aproveita as vantagens intrínsecas do meio online para a aquisição daqueles produtos que envolvem um processo de compra mais planejado, e não a causa em si do fenômeno.

De qualquer forma, esta discussão foge do escopo de avaliação deste trabalho e não altera a relação direta positiva identificada entre as duas variáveis, e constitui um elemento adicional de análise que poderá ser explorado em futuros trabalhos na área.

\subsection{Análise dos resultados - Objetivo específico 4}

O quarto objetivo específico consiste na determinação dos principais dados demográficos do comprador online em relação ao usuário de Internet que não realiza compras pela rede.

É importante ressaltar o fato de que os dados da amostra foram ponderados estatisticamente pelo perfil do usuário de Internet no Brasil seguindo os parâmetros de sexo, faixa etária, escolaridade e renda, o que tenderia a equalizar as diferenças mais significativas entre o processo de amostragem intencional por conveniência e que teria advindo de uma amostragem aleatória, mas a ponderação não leva em conta - e nem seria possível dentro do levantamento de informações conduzido neste estudo e com base nos dados de mercado 
disponíveis - fatores atitudinais ou preferências pessoais sobre a forma de compra, o que restringe a extrapolação das informações para o universo de usuários, e torna os dados apenas uma referência exploratória dos principais dados demográficos do comprador e nãocomprador online, abrindo espaço para futuros trabalhos mais aprofundados sobre esta questão.

A tabela 13 aponta os principais elementos demográficos verificados na pesquisa separando em dois grupos de acordo com a realização ou não de compras pela Internet. 
Tabela 13 - Principais dados demográficos entre compradores e não-compradores online

\begin{tabular}{|c|c|c|c|c|}
\hline & \multirow[t]{2}{*}{$\%$ Coluna } & \multicolumn{3}{|c|}{$\begin{array}{l}\text { q5 - Você já realizou alguma compra de } \\
\text { produtos ou serviços pela Internet? }\end{array}$} \\
\hline & & Não & Sim & Total \\
\hline \multirow{2}{*}{ Sexo } & Feminino & $51 \%$ & $52 \%$ & $52 \%$ \\
\hline & Masculino & $49 \%$ & $48 \%$ & $48 \%$ \\
\hline \multirow{6}{*}{ Faixa Etária } & Até 20 anos & $33 \%$ & $29 \%$ & $30 \%$ \\
\hline & De 21 a 30 anos & $25 \%$ & $36 \%$ & $33 \%$ \\
\hline & De 31 a 40 anos & $27 \%$ & $19 \%$ & $21 \%$ \\
\hline & De 41 a 50 anos & $11 \%$ & $9 \%$ & $9 \%$ \\
\hline & De 51 a 60 anos & $3 \%$ & $5 \%$ & $4 \%$ \\
\hline & Mais de 60 anos & $1 \%$ & $2 \%$ & $1 \%$ \\
\hline \multirow{5}{*}{ Escolaridade } & Ensino fundamental incompleto & $24 \%$ & $10 \%$ & $14 \%$ \\
\hline & $\begin{array}{l}\text { Ensino fundamental completo / Médio } \\
\text { incompleto }\end{array}$ & $18 \%$ & $18 \%$ & $18 \%$ \\
\hline & $\begin{array}{l}\text { Ensino médio completo / Superior } \\
\text { incompleto }\end{array}$ & $48 \%$ & $44 \%$ & $45 \%$ \\
\hline & Ensino superior completo & $5 \%$ & $21 \%$ & $16 \%$ \\
\hline & Pós-graduação & $4 \%$ & $8 \%$ & $7 \%$ \\
\hline \multirow{11}{*}{ Renda } & Menos de $\mathrm{R} \$ 800$ & $69 \%$ & $43 \%$ & $50 \%$ \\
\hline & $\mathrm{R} \$ 800$ a $\mathrm{R} \$ 1.200$ & $17 \%$ & $20 \%$ & $19 \%$ \\
\hline & $\mathrm{R} \$ 1.201$ a $\mathrm{R} \$ 1.500$ & $2 \%$ & $8 \%$ & $6 \%$ \\
\hline & $\mathrm{R} \$ 1.501$ a $\mathrm{R} \$ 2.500$ & $7 \%$ & $11 \%$ & $10 \%$ \\
\hline & $\mathrm{R} \$ 2.501$ a $\mathrm{R} \$ \mathrm{R} \$ 3.500$ & $3 \%$ & $8 \%$ & $7 \%$ \\
\hline & $\mathrm{R} \$ 3.501$ a $\mathrm{R} \$ 4.500$ & $\mathbf{0 \%}$ & $4 \%$ & $3 \%$ \\
\hline & $\mathrm{R} \$ 4.501$ a $\mathrm{R} \$ \mathrm{R} \$ 5.500$ & $0 \%$ & $1 \%$ & $1 \%$ \\
\hline & $\mathrm{R} \$ 5.501$ a $\mathrm{R} \$ 6.500$ & $\mathbf{0 \%}$ & $1 \%$ & $1 \%$ \\
\hline & $\mathrm{R} \$ 6.501$ a $\mathrm{R} \$ 8.000$ & $0 \%$ & $2 \%$ & $1 \%$ \\
\hline & $\mathrm{R} \$ 8.001$ a $\mathrm{R} \$ 10.000$ & $\mathbf{0 \%}$ & $1 \%$ & $1 \%$ \\
\hline & Acima de $\mathrm{R} \$ 10.000$ & $2 \%$ & $1 \%$ & $1 \%$ \\
\hline \multirow{4}{*}{ Estado Civil } & Casado / Mora junto & $26 \%$ & $29 \%$ & $28 \%$ \\
\hline & Divorciado & $5 \%$ & $3 \%$ & $3 \%$ \\
\hline & Solteiro & $69 \%$ & $68 \%$ & $68 \%$ \\
\hline & Viúvo & $0 \%$ & $0 \%$ & $0 \%$ \\
\hline
\end{tabular}

FONTE: Elaborado pelo autor.

A distribuição por gênero não apresenta significativas diferenças no uso da Internet como meio de compra (52\% de homens e $48 \%$ de mulheres entre compradores online, e $51 \%$ de homens e $49 \%$ de mulheres entre não compradores), em linha com os estudos conduzidos por 
Bhatagnar et al. (2000), e não refletindo os resultados dos experimentos conduzidos por Becker (2007) e Teo (2001) com usuários americanos, que apontavam que homens teriam maior propensão à compra online do que mulheres.

Em relação à faixa etária, o grupo comprador online compreende uma frequência de usuários um pouco mais alta entre o público mais jovem. Os compradores online com idade até 30 anos compreendem $65 \%$ do total, comparado aos $58 \%$ que têm até 30 anos, entre os que não realizam compras pela Internet.

Embora o resultado seja aparentemente lógico por uma possível maior afinidade do público jovem com novas tecnologias, a diferença relativamente pequena parece corroborar com a falta de consenso sobre o tema na literatura. Alguns estudos realizados no começo da década demonstraram que o avançar da idade favorece a intenção de comprar pela Internet (BELLMAN et al, 1999; BHATAGNAR et al, 2000; TEO, 2001), porém estudos mais recentes apontam que não há associação significativa entre idade e uso da Internet para compras (BECKER, 2007), ou mesmo que usuários mais jovens são mais afeitos às compras online (ANDERSON, 2006). Embora a diferença registrada seja relativamente pequena, os resultados parecem mais em linha com os registrados nos estudos mais recentes publicados no exterior.

Diferença mais expressiva é encontrada nos resultados referentes à escolaridade. Somados os dois níveis inferiores da escala, que compreendem do ensino fundamental incompleto ao ensino médio incompleto, este grupo de menor nível educacional representa $42 \%$ dos não compradores online, e diminui para $28 \%$ entre os que já realizaram compras pela Internet. Alinhado a este resultado, a soma dos dois níveis superiores da escala (que compreende aqueles com ensino superior completo e pós-graduados) apresenta clara vantagem para o grupo que já realizou compras pela Internet: $28 \%$ contra $9 \%$.

Ainda que parte da diferença verificada na escolaridade pudesse ser atribuída ao perfil etário dos respondentes - o que por si só não poderia justificar a totalidade da diferença, uma vez que as diferenças nos grupos etários é inferior à verificada na escolaridade -, o resultado é bastante coerente com o verificado na distribuição pela faixa de renda, que a literatura mostra guardar associação direta com o nível de escolaridade (BLANDEN, GREGG, 2004). 
Os resultados apontam que $86 \%$ dos usuários de Internet não compradores de lojas online estão na faixa de renda até $\mathrm{R} \$ 1.200$, enquanto $63 \%$ dos compradores estão neste mesmo grupo. Na outra ponta de análise, $6 \%$ dos compradores em lojas online possuem renda acima de $\mathrm{R} \$ 4.500$ mensais, comparado aos 3\% do grupo que não realiza compras pela Internet.

Em relação ao estado civil, os resultados apresentados não mostram diferenças significativas entre o público comprador e não comprador pela Internet. A principal diferença verificada foi no percentual de casados entre os que não compram (26\% contra $29 \%$ dos que compram online), mas em ambos os públicos, os solteiros representam a ampla maioria (69\% entre não compradores e $68 \%$ entre compradores).

A principal implicação para os profissionais de marketing do varejo online parece ser em relação ao mix de produtos ofertados nas lojas virtuais, devendo ser estruturado de forma a não apenas atender o perfil do público atualmente comprador, mas também pensar em estratégias e formas de conseguir incluir os usuários que hoje estão alheios à compra online, seja porque a oferta não vai ao encontro de suas necessidades ou porque os outros elementos do composto de marketing não foram planejados tendo em vista suas necessidades e desejos. 


\section{CONCLUSÕES, LIMITAÇÕES E RECOMENDAÇÕES}

A revisão da literatura deixou clara a importância da Internet para as empresas de varejo, não apenas pelo que ela representa atualmente como canal de vendas, mas principalmente por seu potencial futuro de receita e de complementaridade aos outros componentes de abordagem ao mercado das empresas (ALBERTIN, 2002; ANDERSON, 2006; ARNOLD et al, 2007; DRUCKER, 1999; EVANS, 1996; GRIFFITH, 1998; LEVY, WEITZ, 1995; LIENTZ, REA, 2001).

Os exemplos de aspectos sobre os quais a Internet exerce influência na empresa são diversos, no entanto, entre os mais comumente verificados nos trabalhos da área estão: ampliação da cobertura geográfica, diminuição dos custos de atendimento, simplificação - e em alguns casos, viabilização - do estabelecimento de políticas de preços dinâmicos, redução de estoques, entre diversos outros aspectos que, em última instância, permitem às organizações de varejo vender mais ou operar de forma mais eficiente (ANDERSON, 2006; ARNOLD et al, 2007; BERMAN, EVANS, 1998; GLOOR, 2001; HART et al, 2000; KELLY, 2004; SLYWOTZKY, MORRISON, 2000; TOLEDO, CRESCITELLI, 2004).

Pela perspectiva do consumidor - entre diversas outras mudanças - o advento da Internet representou uma oportunidade sem paralelos para obter informação em quantidade muito maior do que anteriormente e a custos muito mais reduzidos, comunicar-se com outros usuários, e interagir em tempo real. A consequência deste cenário, de efervescência social, econômica e cultural, é que a rede acabou por impactar também a forma como estes milhões de consumidores se relacionam com empresas e compram produtos e serviços.

Dentro deste contexto, entender o perfil do comprador na Internet e como as principais características e elementos intrínsecos à Internet interferem e influenciam no comportamento de compra online é um desafio atual que vem sendo encarado tanto pelas empresas quanto pelos meios acadêmicos com grande intensidade. 
O foco deste trabalho consiste exatamente em dar uma contribuição à formação do conhecimento na área, pesquisando o comportamento do comprador online brasileiro, por meio da determinação dos seus principais dados demográficos, apontando quais os principais elementos motivadores e inibidores da compra online, identificando se há relação entre o uso da Internet e frequência de compra pelo meio online, e se há relação entre níveis de satisfação pós-compra para aquelas realizadas pela Internet e intenção de compra futura pelo mesmo meio.

Para cumprir tal objetivo, primeiro foi realizada uma revisão bibliográfica acerca do tema com o objetivo de entender o estado da arte do que já havia sido produzido em pesquisa.

Os resultados dos estudos verificados na literatura variam bastante de acordo com o público e o objetivo específico pesquisado, mas permitem entender algumas linhas gerais que serão delineadas a seguir e que foram considerados no desenho do questionário de campo que seria aplicado na segunda etapa do projeto.

De uma forma geral, como principais conclusões, é possível apontar que os consumidores que optam pela Internet como meio para comprar produtos e serviços normalmente o fazem motivados por fatores ligados à facilidade de compra e conveniência, maior sortimento de produtos, nível de informação sobre os produtos e controle sobre o processo de compra (ANDERSON, 2006; CHILDERS et al, 2001; EINWILLER, 2003; HOFFMAN et al, 2002; LYNCH, ARIELY, 2000; WOLFINBARGER, GILLY, 2001).

Outrossim foram verificados trabalhos que apontam uma relação positiva entre o tempo de experiência no uso da Internet e realização de compras online (BECKER, 2007; CORBITT et al, 2003; KIM et al, 2000) em pesquisas realizadas com usuários americanos e europeus.

Não parece haver consenso entre os autores em relação às percepções sobre os níveis de preços praticados neste ambiente, ou se o nível de socialização é efetivamente um elemento motivador ou inibidor do processo de compra pela Internet, assim como se é possível determinar alguma diferença significativa das características demográficas entre compradores e não-compradores (FRANCIS, WHITE, 2004; NICHOLSON et al, 2002; ZEITHAML et al, 2002). 
Como elementos apontados como desmotivadores da compra pela Internet, nos estudos verificados na revisão da literatura, estão a questão da segurança, particularmente em relação à percepção de risco transacional; a impossibilidade de se avaliar fisicamente o produto antes da compra; o tempo adicional de entrega; e a expectativa com possíveis dificuldades de devolução ou troca de produtos que apresentem problemas (ARNOLD et al, 2007; FRANCIS, WHITE, 2004; ZEITHAML et al, 2002)

Não foram encontrados trabalhos analisando ou relacionando a satisfação com produtos comprados online em relação aos comprados em lojas físicas, ou o impacto desta satisfação na intenção de voltar a comprar pelo meio, assim optou-se por uma abordagem original para este estudo.

Como complementação a esta primeira etapa foi realizada uma pesquisa de campo com o objetivo de coletar dados referentes ao comportamento de compra online do público brasileiro para identificar os elementos propostos no projeto de pesquisa.

A pesquisa foi realizada divulgando uma chamada-convite para usuários do serviços de busca do portal Yahoo durante o mês de Janeiro de 2009, e foram obtidas 238 respostas válidas para a análise.

$\mathrm{Na}$ sequência, os dados coletados foram ponderados estatisticamente para que pudessem refletir a distribuição da população brasileira usuária de Internet de acordo com critérios de gênero, faixa etária e escolaridade aferidos pela ComScore e o Ibope NetRatings, os dois principais institutos que realizam a medição de audiência na Web.

Com os dados prontos para a análise, partiu-se para os procedimentos necessários à avaliação de cada um dos objetivos específicos definidos no projeto do trabalho.

Para o objetivo específico 1, que consistia em apontar os elementos motivadores e inibidores da compra online, foi conduzida uma regressão logística para que pudessem ser estabelecidos os diferentes pesos de importância na escolha do meio para execução da compra de cada grupo de fatores avaliado (facilidade de acesso, preço, informação, segurança, conveniência e socialização e afetividade), bem como a avaliação dos usuários em cada um dos fatores, tanto para as lojas online quanto para as lojas físicas. 
A tabela 14 sumariza os principais resultados desta análise.

Tabela 14 - Importância dos elementos para a decisão do meio de compra e diferença das avaliações entre loja online e loja física

\begin{tabular}{lccc}
\hline \multicolumn{1}{c}{ Grupo } & $\begin{array}{c}\text { Importância para } \\
\text { Compra }- \text { Reg. Log. }\end{array}$ & $\begin{array}{c}\text { Soma das diferenças ponderadas } \\
\text { = Loja } \text { Online }- \text { Loja Física }\end{array}$ & Delta \\
\hline Facilidade de Acesso & $22.5 \%$ & +1.34 & +0.30 \\
Preço & $31.9 \%$ & +0.28 & +0.09 \\
Informação & $14.3 \%$ & +0.58 & +0.08 \\
Segurança & $12.6 \%$ & -1.21 & -0.15 \\
Conveniência & $7.3 \%$ & +1.45 & +0.11 \\
Socialização e Afetividade & $11.5 \%$ & -0.97 & -0.11 \\
& $\mathbf{1 0 0 . 0 \%}$ & $\mathbf{+ 1 . 4 7}$ & $\mathbf{+ 0 . 3 1}$ \\
\hline
\end{tabular}

FONTE: Elaborado pelo autor.

As principais conclusões que podem ser traçadas com base nos resultados obtidos são de que nos dois fatores de maior importância para decisão do meio de compra - "Facilidade de acesso" e "Preço" - , a Internet apresenta vantagem em relação às lojas físicas, ainda que no caso do grupo "Preço" a vantagem seja significativamente menor do que no caso do grupo "Facilidade de acesso".

Nos outros componentes de avaliação, que apresentam importância menor na decisão do meio de compra e que portanto atuam mais como diferenciais do que como determinantes de escolha do meio de compra, os grupos "Informação" e "Conveniência" também apresentam uma avaliação mais positiva do meio Internet, e os grupos "Segurança" e "Socialização e afetividade" favorecem que as compras sejam realizadas em lojas físicas.

Como observado na revisão da literatura, os resultados são coerentes com trabalhos realizados anteriormente e possibilitam uma medição de cada fenômeno de forma mais precisa para os usuários compradores brasileiros, além de trazer um elemento novo à avaliação que é a diminuição da importância relativa do grupo "Segurança" na determinação do meio de compra.

Para a avaliação do segundo objetivo específico, que verificou a existência de relação entre experiência no uso da Internet e realização de compras online, foi realizado um cruzamento 
entre os dados relacionados à experiência de uso da Internet pelos usuários em duas vertentes: tempo total de contato com o meio e intensidade de uso semanal da rede; e os dados que indicavam a realização de compras pela Internet nos 12 meses anteriores à realização da pesquisa.

Igualmente conduziu-se um teste de determinação do coeficiente de correlação Kendall tau-b para medição da força de associação entre as variáveis.

Os resultados apontaram relação significativa positiva (coeficiente 0.148 no Kendall tau-b) entre as variáveis "tempo de uso da Internet" e "quantidade de compras realizadas nos últimos 12 meses"; mas bem mais intensa (coeficiente 0.201 no Kendall tau-b) entre "intensidade de uso semanal" e "quantidade de compras realizadas nos últimos 12 meses", o que parece demonstrar que a intensidade da relação com o meio - mais do que o tempo do primeiro contato - exerce influência na relação de uso da Internet para compras online.

Embora tenham sido encontradas pesquisas na literatura da área que tenham revelado a existência de relação entre estes dois fatores (BECKER, 2007; CORBITT et al, 2003; KIM et $a l, 2000)$, não foi verificado nenhum estudo que tenha aplicado o conceito de intensidade de uso da Internet como um indicador de experiência de uso do meio, o que pode representar uma contribuição original deste estudo em relação à forma de mensuração e indicação desta relação para os usuários.

Em relação ao terceiro objetivo específico deste trabalho, da identificação da relação entre satisfação com as compras realizadas pela rede e intenção de compra nos 12 meses seguintes ao levantamento, há claros sinais de uma associação positiva entre as duas variáveis, com um aumento mais do que proporcional na intenção de compra pela Internet conforme cresce o nível de satisfação com os produtos adquiridos anteriormente.

O coeficiente de correlação de Kendall tau-b de 0.259 aponta forte associação positiva entre os dois fatores, e o crescimento da razão de odds entre os dois níveis superiores de intenção de compra ("Muito provável" e "Provável”) sobre os dois níveis inferiores ("Muito improvável” e "Improvável”) indica com clareza a conexão entre as duas variáveis. 
Tabela 15 - Relação entre satisfação pós-compra pela Internet e intenção de compra (\% dos respondentes)

q10 - Em relação às compras realizadas em lojas físicas, como você avalia sua

\% Coluna satisfação com os produtos adquiridos pela Internet?

\begin{tabular}{l|ccccc|}
\cline { 2 - 4 } & $\begin{array}{c}\text { Muito menos } \\
\text { satisfeito }\end{array}$ & $\begin{array}{c}\text { Menos } \\
\text { satisfeito }\end{array}$ & $\begin{array}{c}\text { Mesmo nível } \\
\text { de satisfação }\end{array}$ & Mais satisfeito & $\begin{array}{c}\text { Muito mais } \\
\text { satisfeito }\end{array}$ \\
Muito improvável & $1 \%$ & $14 \%$ & $16 \%$ & $13 \%$ & $3 \%$ \\
Improvável & $28 \%$ & $11 \%$ & $9 \%$ & $5 \%$ & $0 \%$ \\
Talvez compre & $48 \%$ & $43 \%$ & $22 \%$ & $3 \%$ & $0 \%$ \\
Provável & $0 \%$ & $2 \%$ & $21 \%$ & $30 \%$ & $21 \%$ \\
Muito provável & $23 \%$ & $30 \%$ & $33 \%$ & $50 \%$ & $76 \%$ \\
Razão de Odds & $\mathbf{3 0}$ & 47 & $\mathbf{1 1 5}$ & 392 & 2.921
\end{tabular}

FONTE: Elaborado pelo autor.

Os resultados mostram que, vencidos os elementos inibidores da compra online, os consumidores que se sentem mais satisfeitos com os produtos comprados por este meio sentem-se fortemente impelidos a continuar fazendo, aumentando a própria curva de aprendizado da realização da compra pela $W e b$, o que, em última instância, poderia tornar o processo cada vez mais efetivo e satisfatório, fechando um círculo virtuoso que estimularia cada vez mais o usuário a comprar pela Internet em relação às lojas físicas.

Por fim, a determinação dos dados demográficos dos compradores e não compradores online teve como objetivo trazer à discussão características pessoais e sócio-econômicas que pudessem influenciar no processo de compra pelo meio.

A distribuição por gênero não apresentou significativas diferenças entre compradores e não compradores $(52 \%$ de homens e $48 \%$ de mulheres entre compradores online, e $51 \%$ de homens e $49 \%$ de mulheres entre não compradores); já em relação à faixa etária, o grupo comprador online compreende uma frequência de usuários um pouco mais alta entre o público mais jovem. O grupo com até 30 anos de idade compreende $65 \%$ do total de compradores online, comparado aos $58 \%$ que têm até 30 anos entre os que não realizam compras pela Internet.

Embora o resultado seja aparentemente lógico por uma possível maior afinidade do público jovem com novas tecnologias, a diferença relativamente pequena parece corroborar com a 
falta de consenso sobre o tema na literatura (ANDERSON, 2006; BECKER, 2007; BELLMAN et al, 1999; BHATAGNAR et al, 2000; TEO, 2001).

Diferença mais expressiva foi encontrada nos resultados referentes à escolaridade. Somados os níveis inferiores da escala ("Ensino fundamental incompleto" até "Ensino médio incompleto"), este grupo representa $42 \%$ dos não compradores online, e diminui para $28 \%$ entre os que já realizaram compras pela Internet. Como consequência, a soma dos níveis superiores ("Ensino superior completo" e "Pós-graduados") apresenta predominância entre aqueles que já realizaram compras pela Internet: $28 \%$ contra $9 \%$.

Seguindo a mesma relação, os resultados apontaram que $86 \%$ dos não compradores de lojas online estão na faixa de renda de até $\mathrm{R} \$ 1.200$, enquanto $63 \%$ dos compradores estão neste mesmo grupo. Na outra ponta da escala, $6 \%$ dos compradores em lojas online possuem renda acima de R 4.500 mensais, comparado aos 3\% do grupo que não realiza compras pela Internet.

Em suma, a finalidade deste trabalho foi de contribuir à construção do conhecimento em relação aos elementos que exercem influência no processo de decisão de compra pela Internet, explorando em relação ao comprador brasileiro alguns aspectos já pesquisados na literatura internacional e propondo uma abordagem para outras vertentes sobre as quais não foi encontrada pesquisa anterior.

\subsection{Limitações e recomendações}

As avaliações e resultados contidos neste estudo devem ser encarados como produto de um esforço de pesquisa exploratório, e são limitados pelas restrições de tempo e momento na revisão da literatura da área, pela forma de coleta da amostra e pelas técnicas de análise empregadas.

A literatura e o conhecimento produzidos na área crescem de forma acelerada e contínua ao longo dos últimos anos - reflexo da própria importância que o tema vem ganhando no meio acadêmico - com novas descobertas e a revisão de conceitos acontecendo todo o tempo. A 
capacidade deste trabalho absorver este montante de conhecimento evidentemente é bastante limitada, e está circunscrita ao que foi produzido durante um determinado período.

A própria experiência do consumidor com a tecnologia tende a alterar o comportamento de compra dos usuários de Internet ao longo do tempo. Da mesma forma, a evolução tecnológica e o desenvolvimento de mecanismos e formas de superação dos fatores inibidores de compra são preocupações constantes de qualquer empresa varejista na atualidade.

Essencialmente, o próprio comportamento humano não é estático, altera-se não apenas com o passar do tempo e o acúmulo de experiências, mas também com o contexto geográfico, político, econômico e social que o cerca.

Desta forma, assim como em outras áreas que passam por um período de aceleração na produção do conhecimento, é necessário revisar e incluir em trabalhos futuros outros referenciais de comportamento de navegação e como as novas tecnologias que surgem, quase diariamente, mudam e/ou influenciam os elementos atuantes na decisão do meio de compra e na própria forma de compra pela Internet.

Outra importante limitação do trabalho é que a técnica de amostragem utilizada (intencional, por conveniência) por não ser probabilística também não possibilita a inferência dos resultados obtidos neste estudo para a população da Internet como um todo, restringindo as conclusões apenas à amostra estudada.

Ainda que os dados tenham sido ponderados estatisticamente para refletir as principais características da distribuição demográfica da população brasileira usuária de Internet, as técnicas de dimensionamento da amostra, análises estatísticas e os testes de significância aplicados devem servir apenas como referência, não sendo possível justificar teoricamente que as informações obtidas representem o comportamento da população como um todo.

Sugere-se, para um aprofundamento no tema, que futuros estudos partam de algumas das ideias levantadas neste trabalho, expandindo o escopo de análise e realizando a medição por meio de técnicas de amostragens probabilísticas, como forma de ampliar a contribuição ao conhecimento na área. 
Outra limitação diz respeito à escolha das escalas adotadas para medição das variáveis estudadas no trabalho, que podem não refletir com precisão ou não contemplar o devido alcance dos objetos de estudo, bem como o caráter de auto-preenchimento dos questionários, que despropositalmente pode ter deixado margem para alguns dos participantes terem dúvidas no momento da participação.

As limitações de tempo e principalmente de recursos disponíveis impossibilitaram a utilização de métodos mais precisos no levantamento dos dados e realização das análises.

Por fim, há uma série de outros aspectos adjacentes ao estudo conduzido que poderiam ser tornados objetos de estudos futuros, como o papel dos agentes influenciadores na decisão do meio de compra (família, amigos, instituições, etc); a influência da propaganda na decisão dos meios de compra; e a relação entre o tipo de produto comprado e a importância dada a cada grupo de fatores de análise do meio (preço, segurança, conveniência, etc). 


\section{REFERÊNCIAS}

AAKER, D. A. Administração estratégica de mercado. 5. ed. Porto Alegre: Bookman, 2001.

ABDI, H. Kendall rank correlation. Encyclopedia of Measurement and Statistics. Thousand Oaks: Sage, 2007.

AGRESTI, A. Categorical Data Analysis. New York: Wiley-Interscience. ISBN 0-47136093-7, 2002.

ALBERTIN, A. L. Comércio Eletrônico: situação atual e tendências. Projeto de pesquisa desenvolvido com o apoio do Núcleo de Pesquisa e Publicações (NPP), da Escola de Administração de Empresas de São Paulo (EAESP) da Fundação Getúlio Vargas. São Paulo: EAESP/FGV, 2002a.

Comércio Eletrônico: modelos, aspectos e contribuições de sua aplicação. 4. ed. São Paulo: Atlas, 2002b.

AMARATUNGA, D.; BALDRY, D.; SARSHAR, M. Quantitative and qualitative research in the built environment: application of a mixed research approach. Work Study, v. 51, n. 1, p. 17-31, 2002.

ANDERSON, C. The Long Tail: Why the Future of Business is Selling Less of More. New York: Hyperion, 2006.

ANGELO, C. F.; SIQUEIRA, J. Etiquetagem na origem no Brasil: tendências e possíveis consequências. Revista de Administração Mackenzie. São Paulo, ano 4, n. 1, p. 13-24, 2003.

ARNOLD, T.; LANDRY, T.; REYNOLDS, K. Retail online assurances: typology development and empirical analysis. Journal of Marketing Theory and Practice, v. 15, n. 4, p. 299-313, 2007.

BAKER, M. J. Sampling. The Marketing Review, v. 3, p. 103-120, 2002.

BAKOS, J. Y. A strategic analysis of electronic markets. MIS Quarterly, p. 295-310, 1995. Reducing buyer search costs: implications for electronic marketplaces. Management

Science, v. 43, n. 12, p. 1676-1692, 1997. 
BECKER, S. A. Electronic Commerce: Concepts, Methodologies, Tools and Applications. New York: Idea Group, 2008

BELLMAN, S.; GERALD, G. L.; JOHNSON, E. Predictors of online buying: Findings from the Wharton Virtual Test Market. Communications of the ACM [online]. Disponível em: $<$ http://proquest.umi.com>.

BERMAN, B.; EVANS, J. R. Retail Management: a strategic approach. Upper Saddle River: Prentice Hall, 1998.

BLACKWELL, R. D.; MINIARD, P. W.; ENGEL, J. F. Comportamento do Consumidor. São Paulo: Pioneira Thomson Learning, 2005.

BLANDEN, J.; GREGG, P. Family income and educational attainment: A review of approaches and evidence for Britain. Oxford Review of Economic Policy, v. 20, n. 2, p. 245263, 2004.

BOONE, L.; KURTZ, D. Marketing contemporâneo. 8. ed. Rio de Janeiro: Livros Técnicos e Científicos, 1998.

BOYD, H. W.; WALKER, O. C.; MULlinS, J.; LARRÉCHÉ, J. C. Marketing Management, a Strategic Decision-Making Approach. Columbus: McGraw-Hill/Irwin, 2002.

BHATNAGAR, A.; MISRA, S.; RAO, H. R. On risk, convenience and Internet shopping behavior. Communications of the ACM, v. 43, n. 11, p. 98-105, 2000.

BRASSINGTON, F.; PETTITT, S. Principles of Marketing. London: Pitman, 1997.

CHIAGOURIS, L.; LONG, M. Will your online retailing be a site for sore eyes? Marketing Management, v. 16, Issue 2, p. 43-46, mar/apr 2007.

CHILDERS, T. L.; CARR, C. L.; PECK, J.; CARSON, S. Hedonic and utilitarian motivations for online retail shopping behavior. Journal of Retailing, v. 77, n. 4, p. 511-535, 2001.

CHURCHILL Jr., G. A.; PETER J. Marketing: criando valor para os clientes. São Paulo: Saraiva, 2000.

COLWELL, S. R.; AUNG, M.; KANETKAR, V.; HOLDEN, A. L. Toward a measure of service convenience: multiple-item scale development and empirical test. Journal of Services Marketing, v. 22, n. 2, p. 160-169, 2008.

CONSTANTINIDES, E. Influencing the online consumer's behavior: the Web experience. Internet Research, v. 14, n. 2, p. 111-126, 2004. 
CORBITT, B. J.; THANASANKIT, T.; YI, H. Trust and e-commerce: a study of consumer perceptions. Electronic Commerce Research and Applications, v. 2, p. 203-215, 2003.

COX, D. F.; RICH, S. U. Perceived risk and consumer decision-making: the case of telephone shopping. Journal of Marketing Research, v. 1, n. 4, p. 32-39, 1964.

DAVIS, F. D.; BAGOZZI, R. P.; WARSHAW, P. R. User Acceptance of Computer Technology: A Comparison of TWO Theoretical Models. Management Science, v. 35, n. 8, p. 982-1003, 1989.

DENZIN, N. K.; LINCOLN, Y. S. The discipline and practice of qualitative research. Handbook of Qualitative Research. Thousand Oaks: Sage, 2000.

DEMO, P. Metodologia científica em ciências sociais. São Paulo: Atlas, 1981.

DONTHU N.; GARCIA A. The Internet Shopper. Journal of Advertising Research, v. 39, 1999.

DOUBLECLICK. The Changing Purchase Process, 2004. Disponível em $<$ http://www.doubleclick.com>. Acesso em 20/07/2007.

.. Best Practices for Optimizing Web Advertising Effectiveness, 2006. Disponível em <http://www.doubleclick.com>. Acesso em 20/07/2007.

DRUCKER, P. Desafios Gerenciais para o Século 21. São Paulo: Pioneira, 1999.

E-BIT. Estudo Web Shoppers, 17 ed., 2007. Disponível em <http://www.ebit.com.br>. Acesso em 18/07/2008.

EINWILLER, S. When reputation engenders trust: An empirical investigation in business-toconsumer electronic commerce. Electronic Markets, v. 13, n. 3, p. 196-209, 2003.

ELLIOTT, M.; SPECK, P. Factors that affect attitude toward a retail. Journal of Marketing Theory and Practice, Winter, 2005.

EVANS, D. The Merchants in Venice. Computer Weekly, 9 May, p. 34, 1996.

FERRELL, O. C.; HARTLINE, M. D.; LUCAS, Jr.; GEORGE, L. D. Estratégia de Marketing. São Paulo: Atlas, 2000.

FLEURY, A. L. Dinâmicas organizacionais em mercados eletrônicos. São Paulo: Atlas, 2001. 
FOLKES, V. S. Consumer reactions to product failure: An attributional approach. Journal of Consumer Research, v. 10, n. 4, p. 398, 1984.

FRANCIS, J. E.; WHITE, L. Value across fulfillment-product categories of Internet shopping. Managing Service Quality, v. 14, n. 2/3, p. 226-234, 2003.

FREEMAN, C. Networks of Innovators: A Synthesis of Research Issues. Research Policy, v. 20, p. 499-514, 1991.

GALHANONE, R. F. Atitudes, emoções e comportamento de compra: um estudo com consumidores de produtos de luxo ou sofisticados. São Paulo, 1988. Dissertação (Mestrado em Administração de Empresas) - PPGA -FEA - Universidade de São Paulo.

GEFEN, D.; STRAUB, D. The relative importance of perceived ease of use in IS adoption: a study of e-commerce adoption. Journal of the Association for Information Systems, v. 1, n. 8,2000 .

GIL, A. C. Técnicas de pesquisa em economia e elaboração de monografias. São Paulo: Atlas, 2000.

GILGUN, J. F. The four cornerstones of qualitative research. Qualitative Health Research, v. 16, n. 3, p. 436-443, 2006.

GLADWELL, M. The Tipping Point. New York: Back Bay Books, 2002.

GLOOR, P. Transformando a empresa em e-business: como ter sucesso na economia digital. São Paulo: Atlas, 2001.

GREWAL, D.; IYER, G. R.; KRISHNAN, A. S. The Internet and the price-value-loyalty chain. Journal of Business Research, v. 56, n. 5, p. 391-398, 2003.

GRIFFITH, D.; KRAMPF, R. An examination of the web-based strategies of the top 100 US retailers. Journal of Marketing Theory and Practice, 1998.

GRISI, C. C. H. Condições que favorecem o surgimento da dissonância cognitiva. In: Apostila - Série: Comportamento do Consumidor, 2006.

HAIR, J. F.; ANDERSON, R. E.; TATHAM, R. L.; BLACK, W. C. Análise Multivariada de Dados. 5 ed. Porto Alegre: Bookman, 2005.

HART, C.; DOHERTY, N.; ELLIS-CHADWICK, F. Retailer adoption of the Internet. European Journal of Marketing, v. 34, n. 8, p. 954-974, 2000. 
HAZEL, D. Non store retail comes together with chains. Chain Store Age State of the Industry, Suplemento, p. 32A-33A, ago. 1996.

HILBE, J. M. Logistic Regression Models. Chapman \& Hall/CRC Press. ISBN 978-1-42007575-5, 2009.

HOFFMAN, D. L.; NOVAK, T. P.; CHATERJEE, P. Commercial scenarios for the web: opportunities and challenges. Journal of Computer Mediated Communications, v. 3, p. 1$20,1995$.

.; ___ SCHLOSSER A. E. Locus of Control, Web use, and Consumer Attitudes Toward Internet Regulation. Information Society, v. 15, n. 2, p. 129-139, 2002.

HUIZINGH, E. The content and design of web sites: an empirical study. Information \& Management, v. 37, n. 3, p. 123-134, 2000.

HUTT, M.; SPEH, T. W. B2B: Gestão de marketing em mercados industriais e organizacionais. Porto Alegre: Bookman, 2002.

JANAL, D. Como fazer marketing na Internet: como anunciar, promover e vender produtos e serviços na Internet e nos serviços de informação online. Rio de Janeiro: Infobook, 1996.

JOBBER, D. Principles \& Practice of Marketing. New York: McGraw-Hill, 2001.

KIM, D. J.; CHO, B.; RAO, H. R. Effects of consumer lifestyle on purchasing behavior on the Internet: A conceptual framework and empirical validation. Proceedings of the $\mathbf{2 1}^{\text {st }}$ Internacional Conference on Information Systems (p. 688-695). Atlanta, GA: Association for Information Systems.

KOTLER, P. Marketing Management. 11th ed. New Jersey: Prentice-Hall, 2003.

LADEIRA, R. Razões que Levam Consumidores Brasileiros a Comprarem pela Internet. Tese (Doutorado em Administração) - PPGA - FEA - Universidade de São Paulo. São Paulo, 2000 .

LAKATOS, E. M.; MARCONI, M. A. Metodologia Científica. 3 ed. São Paulo: Atlas, 2000.

LAN, J. Marketing integrado com a Internet. In: ANGELO, C. F.; SILVEIRA, J.A. Varejo competitivo. São Paulo: Atlas/Provar, 1999.

LEVY, M.; WEITZ, B. Retail Management: A Strategic Approach. 2th ed. New York: Irwin, 1995. 
LIENTZ, B. P.; REA, K. P. Transforming your Business into E. California: Academic, Press, 2001.

LINDEN, C. Compras em supermercados eletrônicos: existem barreiras? Rio de Janeiro, 2004. Dissertação (Mestrado em Administração) - Programa de Pós- Graduação em Administração da PUC-Rio.

LYNCH J. G.; ARIELY, D. Wine Online: Search Costs Affect Competition on Price, Quality and Distribution. Marketing Science, 2000.

MARTINS, G. A. Manual para elaboração de monografias e dissetações. 3. ed. São Paulo: Atlas, 2002.

MASON, J. B.; MAYER, M. L.; EZELL, H. F. Retailing. Business Publications Inc, 1998.

McKENNA, R. Redefinindo o marketing na era da tecnologia. Gestão Plus, n. 16, p. 1011 , set/out 2000 .

MEUTER, M. L.; OSTROM, A. L.; ROUNDTREE, R. I.; BITNER, M. J. Self-service technologies: Understanding customer satisfaction with technology-based service encounters. Journal of Marketing, v. 64, n. 3, p. 50-64, 2000.

MITTAL, V.; KAMAKURA, W. Satisfaction, repurchase intent, and repurchase behavior: Investigating the moderating effect of customer characteristics. Journal of Marketing Research, v. 38, n. 1, p. 131, 2001.

MORGANOSKY, M. A. Retailing and the Internet: a perspective on the top 100 U.S. retailers". International Journal of Retail \& Distribution Management, v. 25, n. 11, p. 372-377, 1997.

NEGROPONTE, N. A Vida Digital. São Paulo: Companhia das Letras, 1995.

NICHOLSON, M.; CLARKE, I.; BLAKEMORE, M. One brand, three ways to shop: Situational variables and multichannel consumer behavior. The International Review of Retail, Distribution and Consumer Research, v. 12, n. 2, p. 131-148, 2002.

PORTER, M. E. Strategy and the Internet. Harvard Business Review, Boston, p. 63-78, March 2001.

OllVEIRA, E. C. Comportamento do Consumidor: Processo de decisão de compra de livros pela Internet. São Paulo, 2007. Dissertação (Mestrado em Administração de Empresas) - PPGA - FEA - Universidade de São Paulo. 
PETTY, R. E.; CACIOPPO, J. T.; SCHUMANN, D. Central and Peripheral Routes to Advertising Effectiveness: The Moderating Role of Involvement. Journal of Consumer Research, v. 10, n. 2, p. 135, 1983.

PORTER, M. Strategy and the Internet. Harvard Business Review, March 2001.

PORTO. Internet e varejo virtual. In: PARENTE, J. Varejo no Brasil: gestão e estratégia. São Paulo: Atlas, 2000.

RATCHFORD, B. T.; PAN, X.; SHANKAR, V. On the efficiency of Internet markets for consumer goods. Journal of Public Policy \& Marketing, v. 22, n. 1, p. 4-16, 2003.

REICHHELD, F.; SCHEFTER, P. E-Loyalty: Your secret weapon on the web. Harvard Business Review, 2008.

ROGERS, E. M. The Diffusion of Innovations, 4th ed. New York: Free Press, 1995.

SEIDERS, K.; BERRY, L.; GRESHAM, L. Attention retailers! How convenient is your convenient strategy. Sloan Management Review, p. 79-89, 2000.

SHARMA, A. Trends in Internet based business to business marketing. Industrial Marketing Management, v. 31, n. 2, p. 77-84, 2002.

SHET, J. N.; MITTAL, B.; NEWMAN, B. I. Comportamento do Cliente: Indo Além do Comportamento do Consumidor. São Paulo: Atlas, 2001

SILVERMAN, D. Qualitative research: meanings or practices? Information Systems Journal, v. 8, n. 1, p. 3-20, 1998.

SIQUEIRA, J. P. A Internet e o varejo: uma análise dos interesses da oferta e preferências dos consumidores. São Paulo, 2004. Tese (Doutorado em Administração de Empresas) PPGA - FEA - Universidade de São Paulo.

SLYWOTZKY, A.; MORRISON, D. J. How digital is your business? New York: Crown Publishing Group, 2000.

SOLOMON, M. R. Consumer Behavior: buying, having and being. 4th ed. New Jersey: Prentice-Hall, 1998.

Prentice-Hall, 2003. .; STUART, E. W. Marketing, Real People, Real Choices. 3rd ed. New Jersey:

SPILLER, P.; LOHSE, G. L. A classification of Internet retail stores. Internet Journal of Electronic Commerce, v. 2, p. 29, 1997. 
TELLES, R. B2B Marketing Empresarial. São Paulo: Saraiva, 2003.

TEO, S. H. T. Demographic and motivation variables associated with Internet usage activities. Internet Research, v. 11, n. 2, p. 125-137, 2001.

TOLEDO, G. L. O composto de marketing no contexto estratégico da Internet. Revista de Administração do Mackenzie. São Paulo: ano 3, n.1, p. 33-78, 2003.

.; PEREIRA, C.B.; CRESCITELLI, E. A Internet como ferramenta competitiva e de marketing no varejo de livros. Estratégias para o Desenvolvimento e Inserção Global. Itapema, SC: SLADE, 2004.

TURBAN, E. Electronic Commerce: a Managerial Perspective. New Jersey: Prentice-Hall, 2000.

WOLFINBARGER, M.; GILLY, M. C. Shopping online for freedom, control and fun. California Management Review, v. 43, p. 34-55, 2001.

ZALTMAN G.; STIFF, R. Theory of Diffusion. In: WARD S.; ROBERTSON, T. S. Consumer Behavior: Theoretical Sources. Englewood Cliffs: Prentice-Hall, p. 416-468, 1973.

ZEITHAML, V. A.; PARASURAMAN, A.; MALHOTRA, A. Service quality delivery through Websites: A critical review of extant knowledge. Academy of Marketing Science Journal, v. 30, n. 4, p. 362-376, 2002. 


\section{APÊNDICE}

\section{- Questionário - Pesquisa de campo}

Gostaríamos de convidá-lo a participar de uma pesquisa sobre hábitos de navegação entre usuários de Internet. Esta pesquisa é parte de um projeto de mestrado na Universidade de São Paulo (USP) e não levará mais do que 10 minutos para ser respondida.

Suas respostas são CONFIDENCIAIS. É muito importante que você responda o questionário até o final.

Como agradecimento pela sua participação, vamos sortear um ****** IPOD NANO 8 GB ****** entre os que responderem! Não esqueça de indicar seu email ao final da pesquisa para podermos contatá-lo!

Há quanto tempo foi seu primeiro contato com a Internet?

( ) Menos de 1 ano

( ) Entre 1 e 2 anos

( ) Entre 2 e 3 anos

( ) Entre 3 e 4 anos

( ) Entre 4 e 5 anos

( ) Mais de 5 anos

Em média, quantas horas por semana você passa acessando a Internet?

( ) Menos de 1 hora por semana

( ) De 1 a 10 horas por semana

( ) De 10 a 20 horas por semana

( ) De 20 a 30 horas por semana

( ) Mais de 30 horas por semana

Qual é o principal local de onde você acessa a Internet?
( ) De casa
( ) Do trabalho
( ) Da escola / faculdade
( ) Da casa de amigos / familiares
( ) De LAN Houses
( ) De cyber cafés
( ) Outros

No principal local em que você acessa a Internet, a conexão é:

( ) Linha discada (modem)

( ) Ajato

( ) Vírtua

( ) Speedy

( ) Velox 
( ) Outro tipo de banda larga

( ) Rede de empresa

( ) Rede de escola / faculdade

( ) Não sei

Você já realizou alguma compra de produtos ou serviços pela Internet?

( ) $\operatorname{Sim}$

( ) Não

Especificamente nos últimos 12 meses, quantas compras você realizou pela Internet?

( ) Não comprei nos últimos 12 meses

( ) De 1 a 3 vezes

( ) De 4 a 5 vezes

( ) Mais de 5 vezes

De qual das categorias listadas abaixo você já adquiriu produtos pela Internet? Marque todos que se aplicam.

( ) Computadores e/ou acessórios para informática

( ) Livros

( ) CDs, DVDs e MP3

( ) Passagem aérea ou serviços de turismo

( ) Ingresso para eventos, filmes, teatro, etc

( ) Aparelhos eletrônicos

( ) Aparelhos eletrodomésticos

( ) Roupas e acessórios

( ) Flores

( ) Telefonia celulares

( ) Brinquedos e videogames

( ) Automóveis

( ) Cosméticos e perfumaria

( ) Outros - Especifique

Em uma escala de 1 a 5, em que 1 significa "Muito improvável" e 5 significa "Muito provável", como você avalia sua intenção de realizar compras pela Internet nos próximos 12 meses?

( ) 1 - Muito improvável

( ) 2 - Improvável

( ) 3 - Talvez compre

( ) 4 - Provável

( ) 5 - Muito provável

Nos próximos 12 meses, você acredita que a sua quantidade de compras (em número de transações) realizadas pela Internet em relação aos últimos 12 meses será:

( ) 1 - Muito menor

( ) 2 -Menor

( ) 3 - Igual

( ) 4 - Maior

( ) 5 - Muito maior 
Em relação às compras realizadas em lojas físicas (de rua ou em shopping, por exemplo), como você avalia sua satisfação com os produtos adquiridos pela Internet?

( ) Costumo ficar muito menos satisfeito com os produtos comprados pela Internet

( ) Costumo ficar menor satisfeito com os produtos comprados pela Internet

( ) Mais ou menos o mesmo nível de satisfação

( ) Costumo ficar mais satisfeito com os produtos comprados pela Internet

( ) Costumo ficar muito mais satisfeito com os produtos comprados pela Internet

Nos blocos de frases a seguir, indique em uma ESCALA DE 1 a 5 na sua opinião em que medida cada um dos aspectos indicados representa um ponto fraco ou um ponto forte na escolha da realização das compras tanto nas lojas físicas quanto nas lojas online.

Quanto mais próximo de 1, mais sua resposta indica que o fator é considerado um "ponto fraco" para a escolha daquele meio, e quanto mais próximo de 5, mais indica que o fator é considerado um "ponto forte" na escolha daquele ambiente.

Por favor, indique apenas números inteiros na avaliação $(1,2,3,4,5)$ !

Grupo 1 - Facilidade de Acesso: Dê notas de 1 a 5 em que 1 significa que é um "ponto fraco" para escolha daquele ambiente, e 5 que é um "ponto forte".

Facilidade para encontrar o produto

Loja Física Loja Online

Facilidade para encontrar produtos relacionados/complementares

Disponibilidade de acesso (local, horário, etc

Grupo 2 - Preço: Dê notas de 1 a 5 em que 1 significa que é um "ponto fraco" para escolha daquele ambiente, e 5 que é um "ponto forte".

Capacidade de comprar o produto por preços mais baixos

Loja Física Loja Online

Capacidade para comparar preços entre as opções de um mesmo produto

Disponibilidade de opções de pagto e parcelamento adequados às minhas

preferências

Capacidade de negociar melhores condições de preço e prazo de entrega

Grupo 3 - Informação: Dê notas de 1 a 5 em que 1 significa que é um "ponto fraco" para escolha daquele ambiente, e 5 que é um "ponto forte".

\begin{tabular}{l}
\hline \\
\hline Possibilidade de encontrar maior variedade de opções para o produto que \\
eu procuro \\
Capacidade de comparar características das diferentes opções de produto \\
Possibilidade de poder encontrar informações sobre o produto em \\
quantidade e profundidade adequadas ao meu interesse \\
Capacidade de trocar informações sobre o produto com outras pessoas \\
Receber suporte do lojista para informações adicionais \\
\hline
\end{tabular}


Grupo 4 - Segurança: Dê notas de 1 a 5 em que 1 significa que é um "ponto fraco" para escolha daquele ambiente, e 5 que é um "ponto forte".

Loja Física Loja Online

Sentimento de segurança na disponibilização de informações pessoais

(RG, CPF, etc) para realização da compra

Sentimento de segurança na disponibilização de informações de cartão de

crédito ou outras formas eletrônicas de pagamento

Disponibilização de opções de pagamento não-eletrônicas (como cheque,

boleto bancário, etc)

Grupo 5 - Conveniência: Dê notas de 1 a 5 em que 1 significa que é um "ponto fraco" para escolha daquele ambiente, e 5 que é um "ponto forte".

Necessidade de deslocamento para realização da compra

Realização da compra com rapidez

Efetuação da compra de forma prática e conveniente

Grupo 6 - Socialização e Afetividade: Dê notas de 1 a 5 em que 1 significa que é um "ponto fraco" para escolha daquele ambiente, e 5 que é um "ponto forte".

Recebimento de tratamento personalizado

Loja Física Loja Online

Capacidade de tocar ou sentir o produto a ser comprado

Capacidade de tornar o processo de compra prazeroso

Qual é a importância dos fatores indicados na sua decisão sobre o meio de realização de compra (em lojas físicas ou lojas online)? Escolha na escala em que 1 significa "Nada importante" e 5 significa "Muito importante"

( ) Facilidade de acesso

( ) Preço

( ) Informação

( ) Segurança

( ) Conveniência

( ) Socialização e afetividade

Sexo

( ) Masculino

( ) Feminino

Faixa etária

( ) Até 20 anos

( ) De 21 a 30 anos

( ) De 31 a 40 anos

( ) De 41 a 50 anos

( ) De 51 a 60 anos

( ) Mais de 60 anos 
Escolaridade - Indique o nível mais alto que você concluiu

( ) Ensino fundamental incompleto

( ) Ensino fundamental completo / Ensino médio incompleto

( ) Ensino médio completo / Ensino superior incompleto

( ) Ensino superior completo

( ) Pós-graduação

\section{Ocupação principal}

( ) Proprietário de empresa (indústria, comércio, prestação de serviço, etc)

( ) Funcionário público

( ) Funcionário de autarquia, fundação ou economia mista

( ) Funcionário de empresa privada

( ) Aposentado

( ) Autônomo

( ) Profissional liberal

( ) Estudante

( ) Desempregado

( ) Outros - Especifique

Em qual das faixas abaixo está sua renda individual mensal?
( ) Menos de R $\$ 800$
( ) De R\$ 800 a R\$ 1.200
( ) $\mathrm{De} R \$ 1.201$ a $\mathrm{R} \$ 1.500$
( ) De R\$ 1.501 a R $\$ 2.500$
( ) De R\$2.501 a R \$ 3.500
( ) De R\$3.501 a R\$ 4.500
( ) $\mathrm{De} R \$ 4.501$ a $\mathrm{R} \$ 5.500$
( ) De R\$ 5.501 a R\$ 6.500
( ) De R\$ 6.501 a $R \$ 8.000$
( ) De R\$ 8.001 a $\mathrm{R} \$ 10.000$
( ) Acima de R\$ 10.000

Estado de residência

( ) - Drop down menu

Estado civil

( ) Solteiro

( ) Casado / Mora junto

( ) Divorciado

( ) Viúvo

Obrigado por sua participação! Não esqueça de indicar seu email para concorrer ao sorteio do IPOD NANO 8GB no campo de email. 
- Processamento completo - Regressão logística dos dados

\begin{tabular}{|c|c|c|c|c|c|c|c|c|}
\hline & B & S.E. & Wald & df & Sig. & $\operatorname{Exp}(B)$ & Imp. & Fator \\
\hline q11_1 & 1.531646913 & 0.586809071 & 6.812769306 & 1 & 0.009050829 & 4.625788826 & $14 \%$ & q11_1 - Facilidade para encontrar o produto \\
\hline q11_2 & 0.569716691 & 0.516669995 & 1.215881929 & 1 & 0.270170342 & 1.767766156 & $5 \%$ & $\begin{array}{l}\text { q11_2 }-\begin{array}{c}\text { Facilidade } \\
\text { relacionados/complementares }\end{array} \\
\text { para }\end{array}$ \\
\hline q11_3 & -0.063439361 & 0.619809012 & 0.010476153 & 1 & 0.918476425 & 0.938531029 & $3 \%$ & q11_3 - Disponibilidade de acesso (local, horário, etc.) \\
\hline q11_4 & 1.175318807 & 0.479437246 & 6.009631351 & 1 & 0.014228 & 3.23917545 & $10 \%$ & q11_4 - Capacidade de comprar o produto por preços mais baixos \\
\hline q11_5 & -0.274757835 & 0.705944753 & 0.151481201 & 1 & 0.697123869 & 0.759756088 & $2 \%$ & $\begin{array}{l}\text { q11_5 - Capacidade de comparar preços entre as opções de um } \\
\text { mesmo produto }\end{array}$ \\
\hline q11_6 & 1.724213427 & 0.582583113 & 8.75923668 & 1 & 0.003080379 & 5.608108106 & $17 \%$ & $\begin{array}{l}\text { q11_6 - Disponibilidade de opções de pagamento e parcelamento } \\
\text { adequados às minhas preferências }\end{array}$ \\
\hline q11_7 & -0.223632334 & 0.605620784 & 0.136353927 & 1 & 0.711932949 & 0.799609069 & $2 \%$ & $\begin{array}{l}\text { q11_7 - Capacidade de negociar melhores condições de preço e } \\
\text { prazo de entrega }\end{array}$ \\
\hline q11_8 & -0.709156876 & 0.527292511 & 1.808762018 & 1 & 0.178656809 & 0.492058889 & $2 \%$ & $\begin{array}{l}\text { q11_8 - Possibilidade de encontrar maior variedade de opções para } \\
\text { o produto que eu procuro }\end{array}$ \\
\hline q11_9 & 0.033112859 & 0.527790575 & 0.003936136 & 1 & 0.949974634 & 1.033667191 & $3 \%$ & $\begin{array}{l}\text { q11_9 - Capacidade de comparar características das diferentes } \\
\text { opções de produto }\end{array}$ \\
\hline q11_10 & -0.252719709 & 0.495201081 & 0.260444421 & 1 & 0.609814996 & 0.776685549 & $2 \%$ & $\begin{array}{l}\text { q11_10 - Possibilidade de encontrar informações sobre o produto } \\
\text { em quantidade e profundidade adequadas ao meu interesse }\end{array}$ \\
\hline q11_11 & 0.712486263 & 0.460067566 & 2.398334512 & 1 & 0.121464506 & 2.039054589 & $6 \%$ & $\begin{array}{l}\text { q11_11 - Capacidade de trocar informações sobre o produto com } \\
\text { outras pessoas }\end{array}$ \\
\hline q11_12 & -1.166429532 & 0.57302703 & 4.143494789 & 1 & 0.041794798 & 0.311477077 & $1 \%$ & q11_12 - Receber suporte do lojista para informações adicionais \\
\hline q11_13 & 0.751884639 & 0.626207405 & 1.441670553 & 1 & 0.2298692 & 2.12099356 & $6 \%$ & $\begin{array}{l}\text { q11_13 - Sentimento de segurança na disponibilização de } \\
\text { informações pessoais (RG, CPF, etc) para a realização da compra }\end{array}$ \\
\hline q11_14 & -0.913153597 & 0.594404591 & 2.360061704 & 1 & 0.124477266 & 0.401256824 & $1 \%$ & $\begin{array}{l}\text { q11_14 - Sentimento de segurança na disponibilização de } \\
\text { informações de cartão de crédito ou outras formas eletrônicas de } \\
\text { pagamento }\end{array}$ \\
\hline q11_15 & 0.464927979 & 0.536811242 & 0.750115537 & 1 & 0.386439654 & 1.591899535 & $5 \%$ & $\begin{array}{l}\text { q11_15 - Disponibilização de opções de pagamanto não- } \\
\text { eletrônicas (como cheque, boleto bancário, etc) }\end{array}$ \\
\hline q11_16 & 0.095875455 & 0.626716965 & 0.023403024 & 1 & 0.878413677 & 1.100621979 & $3 \%$ & q11_16 - Necessidade de deslocamento para realização da compra \\
\hline q11_17 & -0.043854033 & 0.560860001 & 0.006113785 & 1 & 0.937676364 & 0.957093651 & $3 \%$ & q11_17 - Realização da compra com rapidez \\
\hline q11_18 & -1.174142887 & 0.600619944 & 3.821575145 & 1 & 0.050596652 & 0.309083786 & $1 \%$ & q11_18 - Efetuação da compra de forma prática e conveniente \\
\hline q11_19 & 0.557146042 & 0.59947066 & 0.863778191 & 1 & 0.352683547 & 1.745683277 & $5 \%$ & q11_19-Recebimento de tratamento personalizado \\
\hline q11_20 & -3.618545388 & 0.785611759 & 21.21544266 & 1 & 4.10444E-06 & 0.026821663 & $0 \%$ & q11_20 - Capacidade de tocar ou sentir o produto a ser comprado \\
\hline \multirow[t]{2}{*}{ q11_21 } & 0.686432138 & 0.672698667 & 1.041247766 & 1 & 0.307531452 & 1.986614906 & $6 \%$ & q11_21 - Capacidade de tornar o processo de compra prazeroso \\
\hline & & & & & & 32.6317472 & $100 \%$ & \\
\hline
\end{tabular}


- Resultados da Pesquisa - Não ponderados

\section{- Tempo de contato com a Internet}

\begin{tabular}{|l|c|c|}
\hline \multicolumn{1}{|c|}{ Alternativa } & n & \% \\
\hline Menos de 1 ano & 11 & $4,62 \%$ \\
\hline Entre 1 e 2 anos & 16 & $6,72 \%$ \\
\hline Entre 2 e 3 anos & 15 & $6,30 \%$ \\
\hline Entre 3 e 4 anos & 4 & $1,68 \%$ \\
\hline Entre 4 e 5 anos & 10 & $4,20 \%$ \\
\hline Mais de 5 anos & 182 & $76,47 \%$ \\
\hline
\end{tabular}

- Tempo médio gasto por semana acessando a Internet

\begin{tabular}{|l|c|c|}
\hline \multicolumn{1}{|c|}{ Alternativa } & n & \% \\
\hline Menos de 1 hora por semana & 9 & $3,78 \%$ \\
\hline De 1 a 10 horas por semana & 79 & $33,19 \%$ \\
\hline De 10 a 20 horas por semana & 44 & $18,49 \%$ \\
\hline De 20 a 30 horas por semana & 38 & $15,97 \%$ \\
\hline Mais de 30 horas por semana & 68 & $28,57 \%$ \\
\hline
\end{tabular}

\section{- Principal local de acesso à Internet}

\begin{tabular}{|l|c|c|}
\hline \multicolumn{1}{|c|}{ Alternativa } & n & \% \\
\hline De casa & 158 & $66,39 \%$ \\
\hline Do trabalho & 73 & $30,67 \%$ \\
\hline Da escola / faculdade & 3 & $1,26 \%$ \\
\hline Da casa de amigos / familiares & 0 & $0,00 \%$ \\
\hline De LAN Houses & 2 & $0,84 \%$ \\
\hline De Cyber Cafés & 2 & $0,84 \%$ \\
\hline
\end{tabular}


- Conexão no principal local de acesso à Internet

\begin{tabular}{|l|c|c|}
\hline \multicolumn{1}{|c|}{ Alternativa } & n & \% \\
\hline Linha discada & 22 & $9,24 \%$ \\
\hline Ajato & 2 & $0,84 \%$ \\
\hline Vírtua & 36 & $15,13 \%$ \\
\hline Speedy & 52 & $21,85 \%$ \\
\hline Velox & 29 & $12,18 \%$ \\
\hline Outro tipo de banda larga & 51 & $21,43 \%$ \\
\hline Rede da empresa & 37 & $15,55 \%$ \\
\hline Rede da escola / faculdade & 3 & $1,26 \%$ \\
\hline Não sei & 6 & $2,52 \%$ \\
\hline
\end{tabular}

- Você já realizou alguma compra de produtos ou serviços pela Internet?

\begin{tabular}{|l|c|c|}
\hline Alternativa & $\mathbf{n}$ & $\boldsymbol{\%}$ \\
\hline Sim & 192 & $80,67 \%$ \\
\hline Não & 46 & $19,22 \%$ \\
\hline
\end{tabular}

- Especificamente nos últimos 12 meses, quantas compras você realizou pela Internet?

\begin{tabular}{|l|c|c|}
\hline \multicolumn{1}{|c|}{ Alternativa } & n & $\%$ \\
\hline Não comprei nos últimos 12 meses & 17 & $8,85 \%$ \\
\hline De 1 a 3 vezes & 80 & $41,67 \%$ \\
\hline De 4 a 5 vezes & 31 & $16,15 \%$ \\
\hline Mais de 5 vezes & 64 & $33,33 \%$ \\
\hline
\end{tabular}


- De qual das categorias abaixo você já adquiriu produtos pela Internet?

\begin{tabular}{|l|c|c|}
\hline \multicolumn{1}{|c|}{ Alternativa } & $\mathbf{n}$ & \% \\
\hline Computadores e/ou acessórios de informática & 80 & $10,96 \%$ \\
\hline Livros & 103 & $14,11 \%$ \\
\hline CDs, DVDs e MP3 & 87 & $11,92 \%$ \\
\hline Passagem aérea e/ou serviços de turismo & 71 & $9,73 \%$ \\
\hline Ingresso para eventos, filmes, teatro, etc & 46 & $6,30 \%$ \\
\hline Aparelhos eletrônicos & 89 & $12,19 \%$ \\
\hline Aparelhos eletrodomésticos & 63 & $8,63 \%$ \\
\hline Roupas e acessórios & 22 & $3,01 \%$ \\
\hline Flores & 31 & $4,25 \%$ \\
\hline Telefonia celular & 40 & $5,48 \%$ \\
\hline Brinquedos e videogames & 42 & $5,75 \%$ \\
\hline Automóveis & 5 & $0,68 \%$ \\
\hline Cosméticos e perfumaria & 25 & $3,42 \%$ \\
\hline Outros & 26 & $3,56 \%$ \\
\hline
\end{tabular}

- Em uma escala de 1 a 5, em que 1 significa "Muito improvável", e 5 significa "Muito provável", como você avalia sua intenção de realizar compras pela Internet nos próximos 12 meses?

\begin{tabular}{|l|c|c|}
\hline \multicolumn{1}{|c|}{ Alternativa } & n & \% \\
\hline Muito improvável & 24 & $10,08 \%$ \\
\hline Improvável & 11 & $4,62 \%$ \\
\hline Talvez compre & 34 & $14,29 \%$ \\
\hline Provável & 47 & $19,75 \%$ \\
\hline Muito provável & 122 & $51,26 \%$ \\
\hline
\end{tabular}


- Nos próximos 12 meses, você acredita que a sua quantidade de compras (em número de transações) realizadas pela Internet será em relação aos últimos 12 meses:

\begin{tabular}{|l|c|c|}
\hline \multicolumn{1}{|c|}{ Alternativa } & n & \% \\
\hline Muito menor & 15 & $7,81 \%$ \\
\hline Menor & 20 & $10,42 \%$ \\
\hline Igual & 81 & $42,19 \%$ \\
\hline Maior & 60 & $31,25 \%$ \\
\hline Muito maior & 16 & $8,33 \%$ \\
\hline
\end{tabular}

$192 \quad 100,0 \%$

- Em relação às compras realizadas em lojas físicas (de rua ou shopping, por exemplo), como você avalia sua satisfação com os produtos adquiridos pela Internet?

\begin{tabular}{|l|c|c|}
\hline \multicolumn{1}{|c|}{ Alternativa } & n & \% \\
\hline $\begin{array}{l}\text { Costumo ficar muito menos satisfeito com os } \\
\text { produtos comprados pela Internet }\end{array}$ & 12 & $6,25 \%$ \\
\hline $\begin{array}{l}\text { Costumo ficar menos satisfeito com os produtos } \\
\text { comprados pela Internet }\end{array}$ & 14 & $7,29 \%$ \\
\hline $\begin{array}{l}\text { Mais ou menos o mesmo nível de satisfação } \\
\text { comprados pela Internet }\end{array}$ & 113 & $58,85 \%$ \\
\hline $\begin{array}{l}\text { Costumo ficar muito mais satisfeito com os } \\
\text { produtos comprados pela Internet }\end{array}$ & 20 & $17,19 \%$ \\
\hline
\end{tabular}

$192 \quad 100,0 \%$


- Estado de residência

\begin{tabular}{|c|c|c|}
\hline Alternativa & $\mathbf{n}$ & $\%$ \\
\hline Acre & 3 & $1,32 \%$ \\
\hline Alagoas & 0 & $0,00 \%$ \\
\hline Amapá & 0 & $0,00 \%$ \\
\hline Amazonas & 3 & $1,32 \%$ \\
\hline Bahia & 2 & $0,88 \%$ \\
\hline Ceará & 6 & $2,64 \%$ \\
\hline Distrito Federal & 0 & $0,00 \%$ \\
\hline Espírito Santo & 2 & $0,88 \%$ \\
\hline Goiás & 4 & $1,76 \%$ \\
\hline Maranhão & 1 & $0,44 \%$ \\
\hline Mato Grosso & 3 & $1,32 \%$ \\
\hline Mato Grosso do Sul & 2 & $0,88 \%$ \\
\hline Minas Gerais & 23 & $10,13 \%$ \\
\hline Pará & 1 & $0,44 \%$ \\
\hline Paraíba & 0 & $0,00 \%$ \\
\hline Paraná & 6 & $2,64 \%$ \\
\hline Pernambuco & 7 & $3,08 \%$ \\
\hline Piauí & 0 & $0,00 \%$ \\
\hline Rio de Janeiro & 22 & $9,69 \%$ \\
\hline Rio Grande do Norte & 1 & $0,44 \%$ \\
\hline Rio Grande do Sul & 8 & $3,52 \%$ \\
\hline Rondônia & 0 & $0,00 \%$ \\
\hline Roraima & 0 & $0,00 \%$ \\
\hline Santa Catarina & 3 & $1,32 \%$ \\
\hline São Paulo & 129 & $56,83 \%$ \\
\hline Sergipe & 0 & $0,00 \%$ \\
\hline Tocantins & 1 & $0,44 \%$ \\
\hline
\end{tabular}

